\title{
Signal Transduction in Ribosome Biogenesis: A Recipe to Avoid Disaster
}

\author{
Manuela Piazzi ${ }^{1,2}$, Alberto Bavelloni $^{2}$, Angela Gallo $^{3}$, Irene Faenza 4 (i) and \\ William L. Blalock 1,2,* \\ 1 Istituto di Genetica Molecolare-Luigi Luca Cavalli Sforza, UOS Bologna, Consiglio Nazionale delle \\ Ricerche (IGM-CNR), 40136 Bologna, Italy; manuela.piazzi@gmail.com \\ 2 IRCCS, Istituto Ortopedico Rizzoli, 40136 Bologna, Italy; alberto.bavelloni@ior.it \\ 3 RNA Editing Laboratory, Dipartimento di Oncoematologia, IRCCS, Ospedale Pediatrica Bambino Gesù, \\ 00146 Rome, Italy; angela.gallo@opbg.net \\ 4 Dipartimento di Scienze Biomediche e Neuromotorie, Università di Bologna, 40126 Bologna, Italy; \\ irene.faenza2@unibo.it \\ * Correspondence: william.blalock@cnr.it; Tel.: +39-051-636-6769
}

Received: 8 May 2019; Accepted: 30 May 2019; Published: 3 June 2019

\begin{abstract}
Energetically speaking, ribosome biogenesis is by far the most costly process of the cell and, therefore, must be highly regulated in order to avoid unnecessary energy expenditure. Not only must ribosomal RNA (rRNA) synthesis, ribosomal protein (RP) transcription, translation, and nuclear import, as well as ribosome assembly, be tightly controlled, these events must be coordinated with other cellular events, such as cell division and differentiation. In addition, ribosome biogenesis must respond rapidly to environmental cues mediated by internal and cell surface receptors, or stress (oxidative stress, DNA damage, amino acid depletion, etc.). This review examines some of the well-studied pathways known to control ribosome biogenesis (PI3K-AKT-mTOR, RB-p53, MYC) and how they may interact with some of the less well studied pathways (eIF2 $\alpha$ kinase and RNA editing/splicing) in higher eukaryotes to regulate ribosome biogenesis, assembly, and protein translation in a dynamic manner.
\end{abstract}

Keywords: oncology; nucleus; TP53; PI3K-AKT-mTOR; PKR-eIF2 $\alpha$; MYC; RNA polymerase; RNA splicing; RNA editing; translation

\section{Introduction}

Ribosome biogenesis is the process by which the 47S and 5S ribosomal RNAs (runes) are transcribed, processed, and assembled with the necessary ribosomal proteins to form the small (40S) and large (60S) ribosomal subunits. Once exported to the cytoplasm, the two subunits join, in the presence of mRNA and initiator tRNA to form the pre-initiation complex (PIC) [1]. Further processing results in a mature ribosome. Ribosome biogenesis represents the most expensive, complex, finely tuned, multi-step process that the cell must carry-out; therefore, it happens to be one of the most intricately regulated and controlled. In the case of eukaryotes, the process involves the input of all three RNA polymerases (RNA pol I, RNA pol II, and RNA pol III), 79 ribosomal proteins (33 in the $40 \mathrm{~S}$ subunit and 46 in the 60S subunit), and well over 200 proteins (helicases, splicing factors, and chaperone proteins) and non-coding RNA (ncRNA) species (miRNAs, scaRNAs, and snoRNAs) [1]. The process initiates in the nucleoli and is followed step-by-step with sequential rounds of assembly and modification of the maturing ribonucleoprotein (RNP) complexes as they migrate from the nucleoli to the nucleoplasm and ultimately to the cytoplasm, where the final assembly and maturation steps take place. Mutations in any of the necessary proteins or alterations at practically any of the maturation steps can result 
in dire consequences to the organism, depending on both the penetrance of the alteration and the tissue involved. Thus, ribosome biogenesis is highly regulated with diverse checkpoints to limit the production of altered ribosomes [1,2].

Additionally, the process of ribosome biogenesis is energetically expensive for the cell; its regulation must coincide with the environmental conditions in which the cell finds itself and with other cellular processes, such as cell division and differentiation. Under low nutrient conditions, ribosome biogenesis and protein synthesis would not be energetically favorable to the cell. Similarly, initiating ribosome biogenesis and protein synthesis at the same moment as cell division rather than prior to or following cellular division would be catastrophic to the cell $[3,4]$. This review aims to examine the major signal transduction events controlling ribosome biogenesis and the initiation of protein synthesis in higher eukaryotes. The role of well-studied pathways in ribosome biogenesis, such as the avian myelocytomatosis viral oncogene homolog (MYC)/MYC-associated factor X (MAX), mouse/human double minute 2 homolog (M/HDM2)-p53, and the phosphotidylinositol-3 kinase (PI3K)-AKR mouse thyoma homologue (AKT)-mammalian target of rapamycin (mTOR) pathways, will be reviewed as well as the roles of the less well studied eukaryotic initiation factor (eIF)-2 $\alpha$ kinase (namely protein kinase $\mathrm{R}(\mathrm{PKR})$ ) and RNA editing/alternate splicing, and how these pathways cross-talk to regulate ribosome biogenesis. Pathologies resulting from perturbations in these pathways will also be discussed.

\section{Ribosome Biogenesis: An Overview}

Ribosome biogenesis is a highly dynamic process in which transcription of the runes, processing/modification of the runes, association of ribosomal proteins (RPs) to the pre-runes, proper folding of the pre-runes, and transport of the maturing ribosomal subunits to the cytoplasm are all combined $[2,5,6]$. In addition to the RPs that represent the structural component of the ribosome, over 200 other non-ribosomal proteins and 75 snoRNAs are required for ribosome biogenesis. The final product is a functional ribosome, which, in eukaryotes, consists of $40 \mathrm{~S}$ and $60 \mathrm{~S}$ subunits that contain 4 species of processed ribosomal RNAs (18S, 28S, 5.8S, and 5S) and 79 ribosomal proteins (RPs) [2,5-7]. The mature 40S subunit consists of $18 \mathrm{~S}$ rRNA and $33 \mathrm{RPs}$, while the $60 \mathrm{~S}$ subunit consists of 28S, 5.8S, and $5 S$ runes and 43 RPs.

Ribosome biogenesis initiates around nucleolar organizing regions, which contain several hundred copies of the ribosomal DNA (rDNA) genes. In humans, these genes are arranged as head-to-tail palindromes on chromosomes 13, 14, 15, 21, and 22 and encode the $47 \mathrm{~S}$ pre-rRNA transcripts that will later be processed into 28S, 18S, and 5.8S runes [1]. In addition, on a portion of chromosome 1 (human), in association with the nucleoplasm, there are several hundred copies of the $5 \mathrm{~S}$ rDNA gene [1]. The process begins with the association of the upstream binding factor (UBF) and selectivity factor (SL)-1 to the 47S rDNA promoter. This recruits the RNA polymerase I-specific initiation factor RNN3 (TIF-IA) and RNA pol I to the promoter. The RNA pol I complex formation is assisted by the association of the MYC:MAX heterodimer to upstream E-box elements and the binding of additional regulatory factors, which recruit the histone acetyltransferase (HAT) complex, and can be inhibited by the association of p53 or the $\mathrm{pRB} / \mathrm{p} 130$ complex to key proteins of the RNA pol I initiation complex $[1,8,9]$. At the same time, TF-IIIA, TF-IIIB, TF-IIIC, and RNA pol III associate with the $5 \mathrm{~S}$ rDNA promoter. The association of TF-IIIA represents the first step in the assembly of the pol III complex, by both inducing a minor bend in the DNA as well as assisting in the incorporation of TF-IIIC into the polymerase complex. TF-IIIB, in turn, induces a major bend in the DNA at the transcriptional start site [10,11]. Again, this complex formation is assisted by the association of MYC with TF-IIIB, in the absence of MAX, and the recruitment of the HAT complex, and either $\mathrm{p} 53$ or the pRB/p130 complex can suppress RNA pol III-mediated transcription (Figure 1) [8,9]. The 18S, 5.8S, and 28S runes are transcribed by RNA pol I as a single precursor RNA from tandem repeats of the gene into the nucleolus, while the $5 \mathrm{~S}$ rRNA, which is transcribed by RNA pol III from multiple genes into the nucleoplasm, migrates to the nucleolus. RNA pol III is also responsible for the transcription of tRNA genes needed later for translation initiation and elongation. In contrast, the ribosomal proteins, which are present throughout the genome (present on 
20/23 chromosomes counting the sex chromosomes) are transcribed by RNA pol II in association with MYC:MAX and the recruitment of the HAT complex to the promoter $[1,8,9]$. The mRNAs encoding the RPs are processed and transported to the cytoplasm for translation. RNA splicing of these transcripts also produces the scaRNAs and snoRNAs later needed for the formation of diverse heterogeneous ribonucleoprotein (hnRNP) complexes, C/D snoRNPs, and H/ACA snoRNPs that function in mRNA splicing and rRNA modification/maturation (Figure 1) [2,12]. Alternative splicing of RP transcripts also produces "pseudogenes" that regulate the expression/accumulation of RPs (see section on RNA editing and splicing) [13]. Newly translated RPs are then actively imported from the cytoplasm to the nucleolus and nucleoplasm where they are incorporated into the assembling ribosome. This process requires the presence of diverse chaperone proteins that serve several functions: (1) Protect the RPs from degradation, (2) facilitate their active nuclear import, and (3) assume the correct incorporation of the RPs into the maturing ribosome subunits. Recent developments in cryogenic-electron microscopy (cryo-EM) have shed a tremendous amount of light on the process of RP nuclear import and their incorporation into the ribosome. For further information on this aspect of ribosome biogenesis, the reader is encouraged to see the following publications: [12,14-19] (Figure 1).

The initial 47S pre-rRNA transcript maintains a secondary structure at the newly synthesized $5^{\prime}$-end that acts as a platform for the binding and association of an initial set of RPs forming the 90S RNP. As the $5^{\prime}$ portion of the pre-rRNA contains what will become $18 \mathrm{~S}$ rRNA of the $40 \mathrm{~S}$ subunit, the RPs associating with the $5^{\prime}$-end are small subunit RPs or RPSs. Two of the first RPs to associate with the pre-rRNA at the $5^{\prime}$-end are RPS7 and RPS24, which are required to initiate processing and cleavage of the pre-rRNA at the $5^{\prime}$-external transcribed spacer (ETS) (Figure 1). The initial binding of the RPSs and the processing at the $5^{\prime}$-ETS, as well as modifications of the rRNA by ribose methylases (C/D box snoRNPs) and polyuridylases (H/ACA box snoRNPs), energetically favors an rRNA structure that forms a platform for the next round of RPs to associate [2,5,6]. At the same time that processing of the $5^{\prime}$-end of the $18 \mathrm{~S}$ rRNA is being conducted, association of RPS17 and RPS19 facilitate the processing and cleavage at the $3^{\prime}$-end of the $18 \mathrm{~S}$ rRNA within the internal transcribed sequence (ITS1), liberating the assembling $40 \mathrm{~S}$ subunit from the $60 \mathrm{~S}$ subunit $[2,5,6]$. Low levels of RPS7 or RPS24 block or retard rRNA processing, resulting in failed maturation of the $5^{\prime}$-end of the $18 \mathrm{~S}$ rRNA. Similarly, depletion of RPS17 or RPS19 result in failed processing of the $3^{\prime}$-end of the 18S rRNA. Virtually the same process occurs for the formation of the maturing $5.8 \mathrm{~S}$ and $28 \mathrm{~S}$ with the ITS2 (between $5.8 \mathrm{~S}$ and $28 \mathrm{~S}$ sequences). At this point, the associating RPs are RPLs as they will become part of the $60 \mathrm{~S}$ subunit. The process, marked by rounds of rRNA processing and folding and rounds of RP association, continues to occur until the last of the RPs for each subunit are finally incorporated in the cytoplasm [2]. Due to the ability of RNA to assume diverse energy structures at equilibrium, diverse modes of RNP assembly can be occurring simultaneously, including the synthesis of kinetically dead-end products that are aborted and targeted for degradation and recycling by the TRAMP4/5 complex [2,6]. The enzymes and proteins that modify and cleave the 47S rRNA are numerous and the process complex; we invite the reader, for more detail in this aspect of rRNA processing, to refer to the following reviews: Turowski and Tollervey, 2015; Fernandez-Pevida et al., 2015; and Mullineux and Lafontaine, 2012 [20-22].

Several lines of evidence indicate that the main purpose of the RPs is to stabilize rRNA folding and structure, thus assisting in processing; (i) the RPs are RNA-binding proteins that are dependent on RNA structure and conformation, (ii) there are very few protein-protein interactions between the RPs, (iii) while many of the RPs possess a tail that inserts into the ribosome core, the core is, proteically speaking, mostly hollow, with the exception of the rRNA species; and the RP tails apparently do not interact with the mRNA substrate that will later occupy the core [2,5]. In addition to the RPs incorporated into the ribosome and the rRNA modifying proteins, a number of proteins associate with the maturing ribosome in the nucleus to ensure that the ribosome does not prematurely assemble, including the Shwachman-Diamond Syndrome associated protein, SBDS, and eukaryotic initiation factor 6 (eIF6). Once exported into the cytoplasm, these chaperons disassociate from the ribosomal subunits, allowing for ribosomal subunit assembly and the association of mRNA and translation 
initiation factors (IFs) to form the PIC [2,5,6,23,24]. Final steps involving the eIF2, eIF4, and eIF5 complexes result in mature ribosomes and the initiation of protein synthesis. Alteration at any step of this process can have mild to dire consequences depending on the defect and its penetrance. Tissues, which have the greatest rates of proliferation and turn-over, such as the skin and hematopoietic precursors, especially of the erythroid lineage, are often the most affected (Figure 1).

Many RPs also have other trans-regulatory functions [2,25]. Processing of the 60S subunit requires the incorporation of the 5S rRNA, which initially associates with RPL5 and RPL11 to form the 5S RNP. Under the conditions of RP haploinsufficiency or disturbances in ribosome biogenesis as a result of altered signaling or stress, the process of pre-rRNA maturation is arrested, resulting in an increasing pool of unassimilated RPs. The accumulation of free RPs, namely the 5S RNP, results in the inhibition of protein synthesis and cell cycle arrest through the activation of p53 [2,25,26]. Other than enhanced p53 expression, other mechanisms may explain the pro-apoptotic and poor proliferative state observed, following the loss or reduced expression of RPs. Loss of RPL5 or RPL11 was shown to lead to reduced cyclin expression, and therefore, reduced proliferation. Additionally, cells deficient in RPS19 and RPL11 were demonstrated to be predisposed to oxidative stress [2,25]. In addition, an innate immune component has been observed. RP loss/reduction enhances the expression of innate immune genes including interferon and TNF $\alpha$, which is known to contribute to the hematopoietic failure in RPS19 deficiency, likely through IRES-mediated translation [2,26].

Technological advances in microscopy have made it clear that the cell goes to great lengths in order to compartmentalize the phases of ribosome biogenesis. The nucleolus contains several sub-compartments: The fibrillar centers (FCs), the dense fibrillar centers (DFCs), and the granular compartments (GCs). In addition, on the nucleolus/nucleoplasm border there are the Cajal bodies, a distinct subcellular component responsible for non-coding RNA maturation $[27,28]$. The rDNA clusters are located at the FC/DFC interface and thus 47S rRNA synthesis takes place here, while $5 S$ rRNA synthesis occurs in the nucleoplasm, but is then transported to the nucleolus. Many of the early steps in pre-rRNA maturation and pre-RNP (90S and 5S RNPs) assembly occur in the DFC, with later assembly steps requiring the incorporation of additional RPs and rRNA modification by snoRNAs, occurring in the GC. The final RPs are incorporate to form the $40 \mathrm{~S}$ and $60 \mathrm{~S}$ subunits in the nucleoplasm, prior to the export of the individual subunits to the cytoplasm. Interestingly, the Cajal bodies have no role in direct ribosome biogenesis but provide an environment for the maturation/modification of the snRNPs (later required for splicing) and snoRNPs (later required for rRNA processing). These sub-nuclear compartments are defined by their respective protein content with the fibrillar centers (FC/DFC) containing the methyltransferase, fibrillarin, and the Cajal bodies containing coilin. It has been proposed that the exchange between these compartments is free (no active transport necessary), as no membrane exists to define or separate them [27,28]. In this "free exchange model" the composition and ratio of water-soluble nucleic acids to insoluble nucleic acid binding proteins produces a semi-solid plasma state allowing for the free movement of protein-nucleic acid complexes between these compartments. Thus, it would be predicted that much of the order of these compartments is dictated by the localized protein content. 

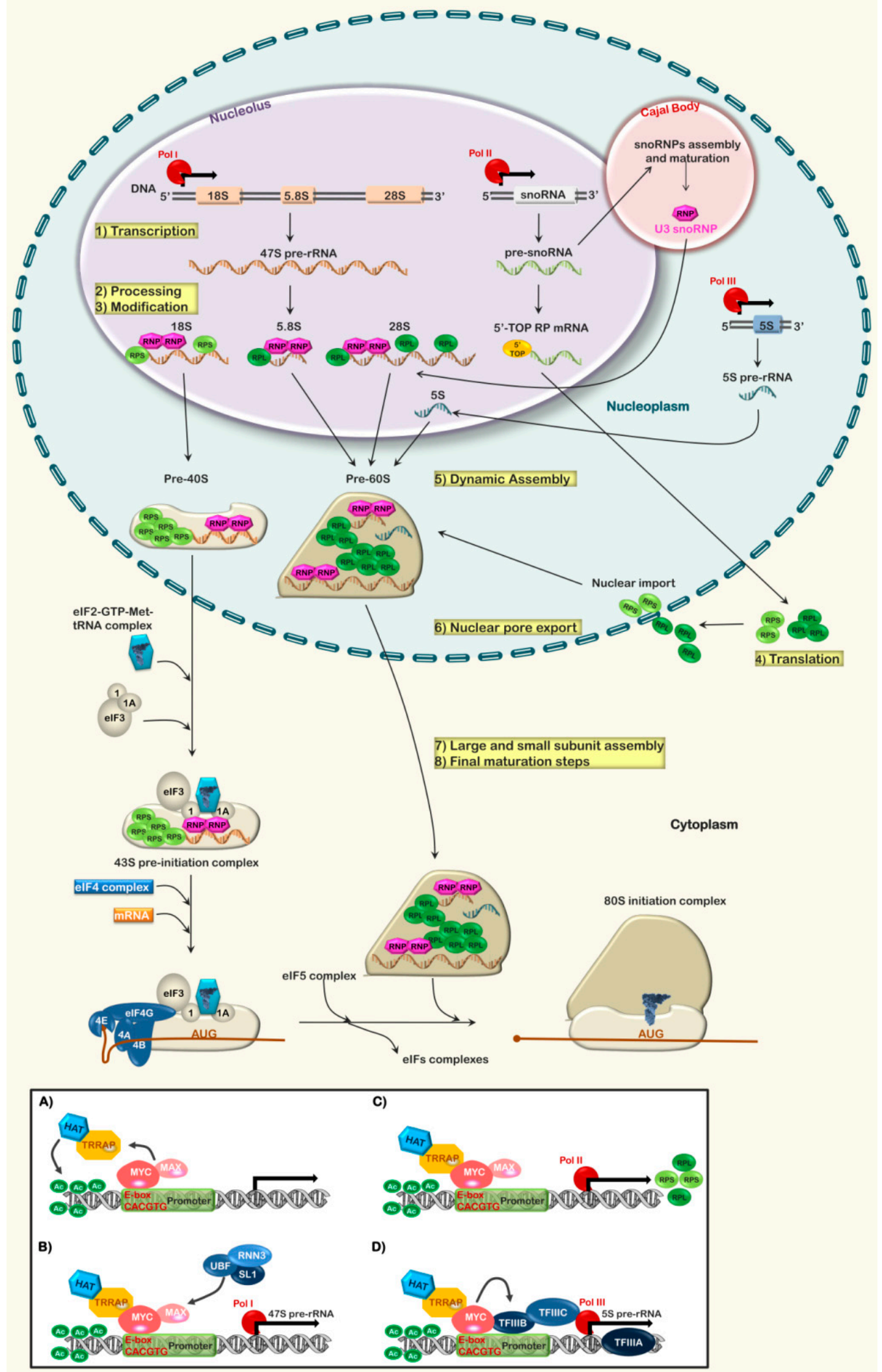

Figure 1. Schematic diagram of ribosome biogenesis and MYC-dependent regulation of rRNA synthesis. The diagram gives a synopsis of the steps involved in ribosome biogenesis and CAP-dependent translation with emphasis to the limiting step, rRNA synthesis. 


\section{MYC a Global Regulator of Ribosome Biogenesis}

It is estimated that approximately $15 \%$ of genes in higher eukaryotes contain MYC-responsive regulatory elements; thus, it is no wonder that overexpression of MYC can induce uncontrolled protein synthesis and cell proliferation. MYC is one of the only transcription factors known to regulate all three of the RNA polymerases (pol I, pol II, and pol III) and, therefore, has the capacity to induce the expression of all required rRNAs, ribosomal proteins, and co-factors necessary for ribosome biogenesis [8,29]. In complex with the MAX protein, MYC binds to E-box elements upstream of the transcriptional start site in the promoter of MYC-responsive genes. Binding of the MYC:MAX heterodimer results in the recruitment of co-regulatory proteins, such as the transformation/transcription domain-associated protein (TRRAP) to the promoter. TRRAP is part of the histone acetyltransferase (HAT) complex, which is responsible for targeting acetylation of histones ( $\mathrm{H} 3$ and $\mathrm{H} 4)$ through the activity of the GCN5 acetyltransferase, thereby opening the DNA for transcription (Figure 1, bottom panel a,c). In the case of rDNA, MYC also results in the recruitment of RNA pol I co-factors UBF and SL-1 to the promoter, thus stimulating the transcription of the $47 \mathrm{~S}$ pre-rRNA (Figure 1, bottom panel b) [8,30,31]. In contrast, MYC influences the transcription of the 5S rRNA and that of tRNAs in a diverse manner. Rather than forming a heterodimer with MAX, MYC associates directly with TF-IIIB in the nucleoplasm to stimulate RNA pol III-mediated transcription of theses RNAs (Figure 1, bottom panel d) [8,32]. Beyond the direct association with rDNA promoters, MYC is also known to influence the expression of the RNA pol I transcriptional co-factor UBP, a MYC-responsive gene product [8,33].

MYC is also known to induce the expression of both the small and large subunit ribosomal proteins, in an RNA pol II-dependent manner. Interestingly, several of these targets RPL 5 and RPL11 have been found to be extremely important in sensing ribosomal stress (see below). RPL11 has been shown not only to induce p53 transactivation, but also to bind MYC within the MYC box II domain and inhibit its association with TRRAP, thereby reducing histone acetylation and MYC-dependent transcription [8,34]. Thus, the MYC-RPL11 circuit functions in a negative-feedback mode. In addition, MYC also induces a number of proteins that are either involved in rRNA processing and transport or in translation initiation. MYC controls the expression of nucleolin (NCL) and nucleophosmin (NPM), two proteins that are involved in multiple processes in the nucleus, including the processing of the 47S rRNA to 18S, 5.8S, and 28S rRNAs; as well as the expression of the nucleolar protein 56 (NOP56), a core component of the C/D box snoRNP complex, block of proliferation 1 (BOP1), part of the PeBoW complex required for $28 \mathrm{~S}$ and 5.S rRNA maturation, and dyskerin (DKC), a H/ACA snoRNP complex subunit responsible for the pseudouridylation of rRNA species $[8,35,36]$. Moreover, NPM has additional roles in the cytoplasmic-nuclear import of newly synthesized ribosomal proteins and the nuclear-cytoplasmic export of the assembling ribosomal subunits. MYC also enhances expression of the translation initiation factors eIF2 $\alpha$, eIF4A-I, eIF4E, and eIF4G, which regulate CAP-dependent translation and may also promote methylation of the mRNA CAP through RNA guaine-7-methytransferase [8,37].

It is now well established that MYC transformation is heavily dependent on an altered rate of protein synthesis. Studies document enhanced protein synthesis in E $\mu-M Y C$ transgenic mice, which rapidly develop tumors. When these mice were crossed with mice containing haplodeficiencies of the genes encoding RPL24 or RPL38, the rate of lymphogenesis was substantially reduced, indicating that reduced protein synthesis, due to the reduce expression of a necessary RP, was able to contrast MYC transformation [38].

Under certain circumstances, MYC is also known to promote apoptosis. Diverse forms of MYC can be expressed by alternate translation initiation. Two main forms, p64 and p67, result from alternate start codon usage. MYC p64 initiates from a standard AUG start codon; in contrast, MYC p67 initiates from a non-canonical upstream start codon (a CUG), which produces a protein that is 15 amino acids longer. Both these forms can associate with E-box elements, while MYC p67 can also associate with CAAT-enhancer binding elements as well, thus affecting the transcription of an additional set of genes $[39,40]$. It has been proposed that the ration of p64 MYC to p67 MYC dictates whether MYC promotes growth/proliferation or apoptosis. 


\section{The PI3K-AKT-mTOR Pathway, Linking Ribosome Biogenesis to Extracellular Signaling}

The PI3K/AKT pathway has become one of the most studied and best characterized signal transduction pathways, due to its involvement in cell survival and proliferation, glucose metabolism, and translation [41]. A large number of cytokine and growth factor receptors, such as the epidermal growth factor receptor (EGFR), the insulin-like growth factor receptor (IGFR), the granulocyte macrophage-colony stimulating factor receptor (GM-CSFR), and the tumor necrosis factor (TNF)- $\alpha$ receptors (TNFR1 and TNFR2) transduce part of their signal through the PI3K-AKT-mTOR pathway. These receptors inform the cell of the surrounding environment, whether to undergo self-renewal or differentiation. In the classical scenario, following ligand binding to its cognate receptor, the regulatory and catalytic domains of the phosphatidylinositol-3 kinase (PI3K) are recruited to the cytoplasmic domain of the receptor and activated. Activated PI3Ks catalyzes the phosphorylation of phosphatidylinositol (PtdIns), PtdIns(4)P, PtdIns(5)P, or PtdIns(4,5)P2 at the 3-position of the inositol ring to form PtdIns(3)P, PtdIns(3,4)P2, PtdIns(3,5)P2, and PtdIns(3,4,5)P3 [41,42]. PtdIns(3,4,5)P3 is the main form involved in AKT activation, and its level in cells is regulated by the phosphatase and tensin homolog (PTEN), the product of the mmac1 gene, which quickly dephosphorylates PtdIns $(3,4,5) \mathrm{P} 3$ to PtdIns(4,5)P2. It is not surprising that the gene encoding PTEN is one of the genes most often mutated or lost in cancer [43]. PtdIns(3,4,5)P3 results in the recruitment of the AKT kinase (AKT1, -2 , or -3 ) via the $\mathrm{N}$-terminal and negative regulatory plekstrin homology $(\mathrm{PH})$ domain. This association not only results in the localization of AKT to membrane components of the cell, but it also causes a conformational change in $\mathrm{AKT}$, removing the negative regulation imposed by the $\mathrm{PH}$ domain, opening up AKT for two phosphorylation events required for its kinase activity. The phosphatidylinositol-dependent kinase, PDK1 is responsible for phosphorylating AKT1 on Thr308 (Thr309 on AKT2 and Thr308 on AKT3). Like AKT, it is recruited to the membrane via its PH domain. Phosphorylation on Thr308 is assisted by phosphorylation of Ser473 in AKT1 (Ser474 in AKT2 and Ser472 in AKT3), which is carried-out by the mTORC2 complex (Figure 2A) [44].

While the AKT kinases show some redundancy in their activity, several major differences have been noticed. AKT1 and AKT2 are ubiquitously expressed, and both are present and have enzymatic roles in the nucleus and cytoplasm. In contrast, the localization of AKT3 is predominantly nuclear, with expression limited to the brain, lung, and kidney in adults; and heart, liver, and brain in fetus. AKT1 is associated more closely with anti-apoptotic/survival effects of PI3K activation, while AKT2 has been shown to be responsible for AKT-dependent insulin signaling. AKT3 is still poorly understood with few substrates identified $[45,46]$.

Multiple substrates of AKT have been identified, but the best understood and most critical by far to ribosome biogenesis is the mTORC1 complex. The mTORC1 and mTORC 2 complexes differ in several ways. First, mTORC1 serves as a substrate for AKT, while mTORC2 is responsible for the phosphorylation of AKT on Ser473. Second, mTORC1 is a rapamycin-sensitive complex while mTORC2 is not. This difference in susceptibility to rapamycin is due to the third major difference in these complexes; the protein components. Both mTORC1 and mTORC2 contain the mammalian target of rapamycin protein (mTOR), the positive/negative regulator G protein $\beta$-subunit-like (G $\beta$ L or LST8), and the DEP-domain containing mTOR-interacting protein (Deptor), a negative regulator of the mTORC complexes; but while mTORC1 contains the scaffolding protein Raptor, mTORC2 contains Rictor, Sin1 (MAPKAP1), and proline-rich protein 5 (PRR5). The mTORC2 complex is nutrient insensitive, acts upstream of Rho-GTPases, and has a role in modifying the actin cytoskeleton. In contrast, the mTORC1 complex is nutrient sensitive and regulates a major part of ribosome biogenesis and CAP-dependent translation (Figure 2B) [42]. 
A

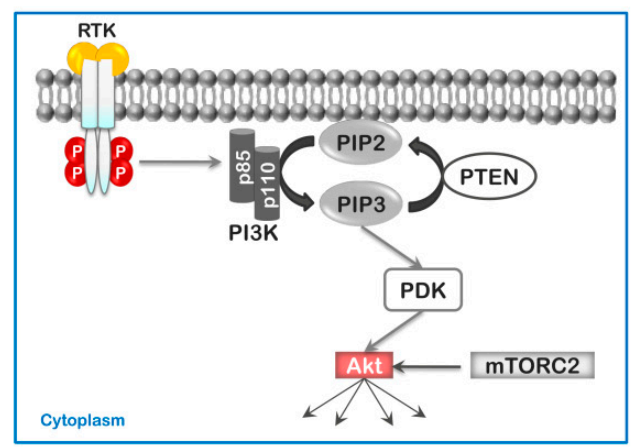

B

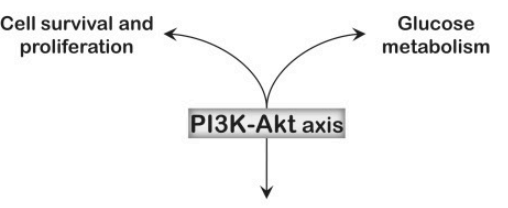

Translation

Ribosome biogenesis
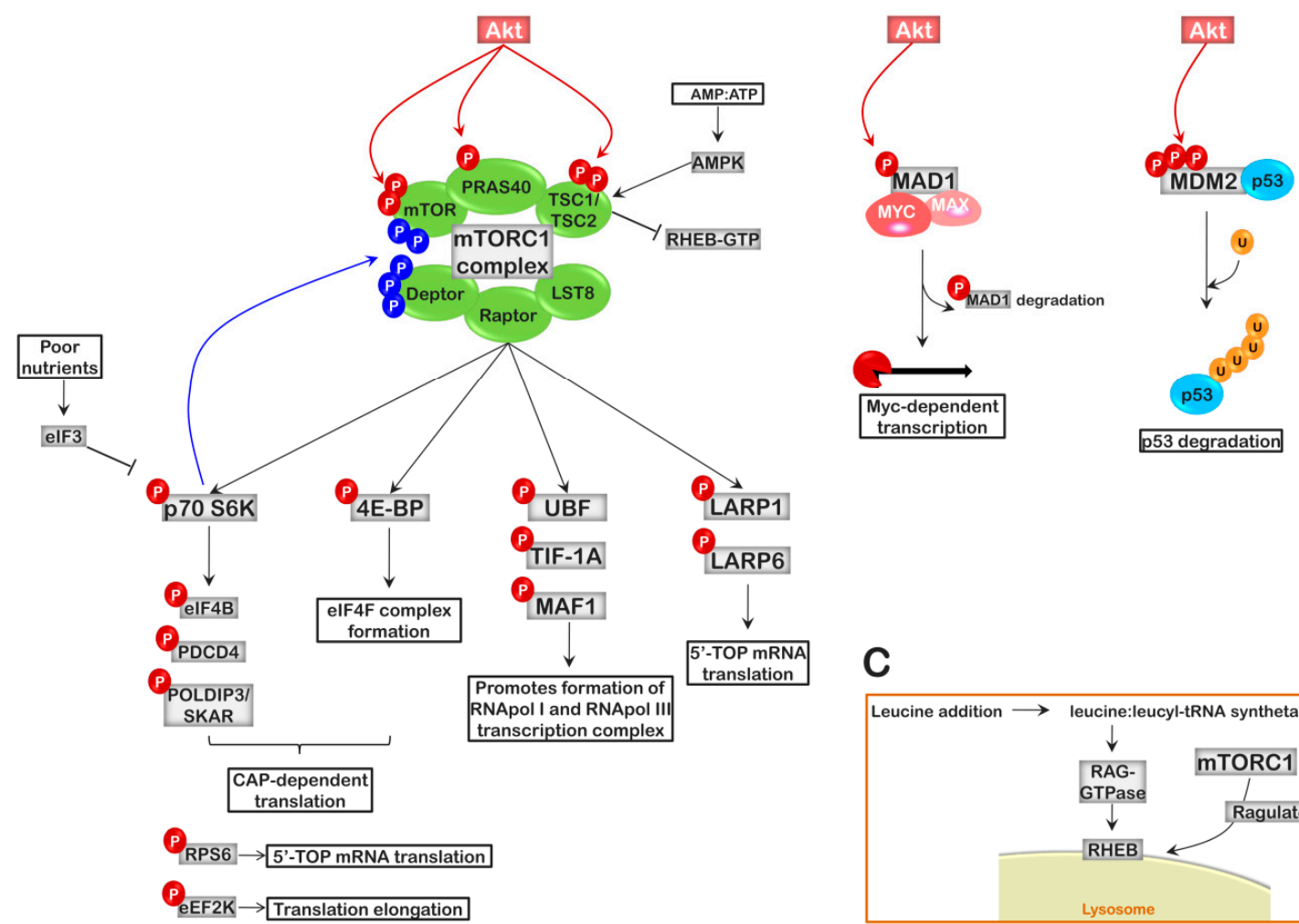

C

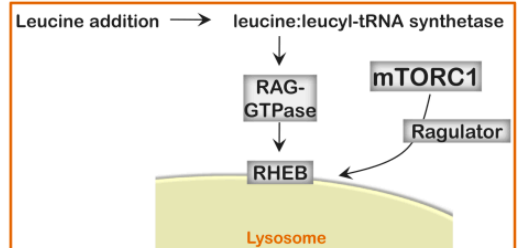

Figure 2. Diagram of the regulation and role of the PI3K-AKT-mTORC1 pathway in ribosome biogenesis and translation initiation. The diagram presents the diverse points of regulation that the PI3K-AKT-mTORC1 signaling pathway has in ribosome biogenesis and translation initiation under optimal as well as suboptimal (low ATP levels, poor nutrients, limited amino acid) conditions. (A) Activation of AKT through the regulation of PIP3 levels; (B) AKT stimulates the mTORC1 complex, which targets multiple downstream targets; (C) L-leucine activation of mTORC1 at the lysosome. Phosphorylation (P) marked in red represent phosphorylations that favor ribosome biogenesis and translation initiation; phosphorylations in blue represent phosphorylations that are inhibitory to ribosome biogenesis or CAP-dependent translation initiation; ubiquitinations are presented in orange. 
The AKT kinases can directly phosphorylate mTOR (Thr2446, Ser2448), which increases the activity of the catalytic subunit, mTOR, but is not sufficient for mTORC1 activation. Activation of the mTORC1 complex occurs through its GTPase Rheb when in the GTP bound state. Rheb is inhibited by its GAP protein(s), the tuberous sclerosis heterodimer (TSC1/TSC2). In addition, the mTORC1 complex is also inhibited by the association of the proline-rich AKT substrate (PRAS40) in a 14-3-3 protein-dependent manner. AKT activates the mTORC1 complex by phosphorylating both PRAS40 (Thr246) and the TSC1/TSC2 (Ser939, Ser981, and Thr1462 of TSC2) complex to free Rheb and stimulate the activation of mTORC1 (Figure 2B) [42,47].

Amino acid activation of $\mathrm{mTORC} 1$ is also possible. This involves the recruitment of $\mathrm{mTORC} 1$ by the Ragulator protein complex to the lysosomal membrane, following stimulation with amino acids, where mTORC1 interacts with its activator Rheb, bringing the mTORC1 complex in contact with the Rag GTPases. The heterodimeric Rag GTPases, consisting of RagA or RagB pairing with RagC or RagD, become loaded with GTP in the presence of amino acids, favoring their interaction with Raptor and the activation of mTORC1 [48-50]. Nicklin et al. demonstrated that it was glutamine uptake and its subsequent efflux in the presence of essential amino acids, which is the limiting step in this process $[48,51]$. The uptake of glutamine by the cell establishes an internal reservoir of glutamine that can be exported by the heterodimeric SLC7A5-SLC3A2 antiporter. The efflux of glutamine by the antiporter promotes the import of branched-chain amino acids such as leucine [48,51]. This increased presence of intracellular leucine favors the interaction of leucine with leucyl-tRNA synthetase. The leucine:leucyl-tRNA synthetase complex then acts as a GTPase-activating protein stimulating the Rag GTPases [48,52]. So why leucine? Leucine happens to be the amino acid most frequently used in proteins, thus, its deficiency should set-off alarms for the cell. For this reason, it has been observed that some ribosomopathy patients can be treated with leucine supplements (see below). Moreover, the presence of Raptor in the complex assists in the recruitment of mTORC1 substrates (Figure 2C).

Finally, the activity of the mTORC1 complex can be regulated directly by the energy level of the cell. Low cellular ATP levels result in the activation of the adenosine monophosphate activated kinase (AMPK), which can phosphorylate and activate TSC2, of the TSC1-TSC2 inhibitory complex, on Thr1227 and S1345; and/or phosphorylate Raptor on Ser722 and Ser792, promoting its interaction with 14-3-3 proteins and the inhibition of mTORC1 (Figure 2) [53,54]. In addition, AKT has the ability to autoregulate its phosphorylation at Ser473 through the phosphorylation Sin1 (Thr86) to down-regulate mTORC2 activity [55].

The mTORC1 complex phosphorylates two main targets of ribosome biogenesis, the S6 kinases (p70 S6K1/p70 S6K2) and the eIF4E-binding protein (4E-BP). Recruitment of the $40 \mathrm{~S}$ ribosomal subunit to the $5^{\prime} \mathrm{N}^{7}$-methyl guanosine CAP $\left[\mathrm{m}^{7} \mathrm{G}\left(5^{\prime}\right) \mathrm{ppp}\left(5^{\prime}\right) \mathrm{N}\right]$ of mRNA is facilitated by the eIF4F translation initiation complex, which is composed of the cap-binding protein eIF4E, the scaffold protein eIF4G, and the RNA helicase eIF4A. Unphosphorylated 4E-BP associates with eIF4E, blocking the association of eIF4E with eIF4G. Phosphorylation of 4E-BP, mediated by mTORC1, frees eIF4E, facilitating its association with eIF4G and the formation of the eIF4F complex; thus, favoring CAP-dependent translation. The reduced efficiency of the eIF4F complex to recognize and promote the translation of $5^{\prime}$ $\mathrm{N}^{7}$-methyl guanosine CAPed mRNAs favors internal ribosome entry site (IRES)-mediated translation, which is often observed during inflammation and stress [42,56]. On the other hand, phosphorylation of the p70 S6 kinase, results in its activation and the subsequent downstream phosphorylation of PDCD4 (Ser67; an inhibitor of eIF4A), causing its ubiquitination and proteolysis, and eIF4B (Ser422; an activator of the eIF4A helicase), thus, favoring CAP-dependent translation of mRNAs with complex secondary structure at the $5^{\prime}$-end [57-59]. Additionally, p70 S6K also phosphorylates polymerase delta-interacting protein 3 (POLDIP3/SKAR) on Ser383 and Ser385, favoring nuclear export and translation of spliced over non-spliced mRNAs [60]. Under poor nutrient conditions, the eIF3 initiation complex associates with p70S6K and sequesters it in an inactive state. Following the appropriate stimulus, eIF3 is released and p70 S6K phosphorylates its targets (Figure 2B) [61]. 
Beyond CAP-dependent translation initiation, the AKT-mTORC1-p70 S6 kinase pathway has been demonstrated to target other effectors of ribosome biogenesis. AKT has been shown to phosphorylate MAD1 on S145, resulting in its release from the MYC/MAX/MAD1 heterotrimer, and its degradation to form the active MYC/MAX heterodimer; thus, promoting MYC-dependent transcription $[9,62]$. AKT also phosphorylates and stabilizes MDM2 (S166, S186, and S188), favoring the degradation of p53, a major repressor of ribosome biogenesis (see below). In addition, AKT may regulate the type of mRNA translated based on its 5' UTR through phosphorylation of LARP6 (S451), a protein that associates with stem-loops in the 5'UTR to stabilize mRNA. Phosphorylation of LARP6 at S451 results in LARP6 degradation [63]. Likewise, mTOR phosphorylates LARP6 (S340, S409) and its family member LARP1 (S766, S774), but in contrast to AKT-dependent phosphorylation, mTOR-dependent phosphorylation promotes the stability and sequestering of these proteins; thus, favoring the translation of mRNAs containing the $5^{\prime}$ terminal oligopyrimidine (TOP) motif, a $5^{\prime}$-cytidine followed by a short pyrimidine tract (4-14 nucleotides) immediately downstream of the methyl guanidine cap ( $\mathrm{m}^{7} \mathrm{Gppp}$ ) (Figure 2B). The 5'TOP mRNAs encode components of ribosome biogenesis such as the RPS and RPL proteins $[64,65]$. Moreover, mTORC1 is able to stimulate RNA pol I-dependent transcription of the 47S rRNA by activation of UBF and TIF-1A; and RNA pol III-dependent transcription of 5S rRNA and tRNA through its direct recruitment to the promoter, by TF-IIIB, and subsequent phosphorylation of MAF1 (S60, S68, and S75), an inhibitor of the TF-IIIB complex formation; thus, establishing a role for mTORC1 as a transcription factor. Use of the mTOR inhibitor rapamycin blocks the synthesis of rDNA by inhibiting the formation of the RNA pol I and RNA pol III transcription complexes on their respective promoters $[9,66,67]$. It is also apparent that mTOR may also regulate the balance between mTORC1 and mTORC2 complex formation by phosphorylating diverse components of the mTORC complexes, including itself. Finally, the p70 S6 kinases also phosphorylate RPS6 and the eukaryotic elongation factor $2 \alpha$ (eEF2 $\alpha$ ) kinase (eEF2K) [68,69]. Phosphorylation of RPS6 results in the enhanced translation of 5'TOP RNAs, while phosphorylation of eEF2K results in inhibition of its catalytic activity and the activation of eEF $2 \alpha$, favoring translation elongation. RPS6 can also be phosphorylated by p90 RSK, which is activated downstream of the RAS-RAF-ERK pathway activation [70]. In addition to these, p70 S6K appears to also regulate AKT and mTORC1 activity through phosphorylation of Thr2446 and Ser2448 of mTOR and the phosphorylation and targeted degradation of Deptor (Ser286, Ser287, and Ser291) and Rictor (Thr1135). The phosphorylation of Rictor is considered a negative feedback modification as it results in decreased mTORC2 phosphorylation of AKT [71-73].

Recently, Bavelloni et al. reported a study in which they sought to identify novel nuclear AKT substrates. Using phospho-AKT substrate specific antibodies coupled with mass spectrometery analysis, the authors identified a set of proteins present in the nuclear lysates of two hematopoietic cell lines that were immunoprecipitated with antibodies recognizing the following epitopes: $K / R-x-K / R-x-x-S^{*} / T^{*}$ or $\mathrm{R}-\mathrm{x}-\mathrm{x}-\mathrm{S}^{*} / \mathrm{T}^{*}$; where " $\mathrm{x}$ " represents any amino acid and the asterisk represents a phosphorylated amino acid. The authors then analyzed the identified proteins to determine if they actually contained sites that could be recognized by the antibodies employed in the study. Both AKT and p70 S6K belong to the AGC kinase family and have similar phosphorylation consensus sites; thus, the identified proteins may represent both AKT and p70 S6K substrates (Table 1). Many of the identified proteins are intimately related to ribosome biogenesis [74]. Thus, it is possible AKT-mTOR-p70 S6K signaling has additional targets that influence ribosome biogenesis and translation initiation that have yet to be characterized. 
Table 1. Identified by tandem affinity purification-mass spectrometry (AP-MS/MS) using anti-AKT/p70 S6K phosphosubstrate antibodies.

\begin{tabular}{|c|c|c|c|c|c|c|}
\hline Acc \# & Gene Name & Name & Function & $\begin{array}{c}\text { AKT } \\
\text { pSites }\end{array}$ & $\begin{array}{l}\text { Known } \\
\text { Sites }\end{array}$ & $\begin{array}{l}\text { AKT/p70 } \\
\text { S6K Sub }\end{array}$ \\
\hline P55265 & $A D A R$ & $\begin{array}{l}\text { Double-stranded RNA-specific } \\
\text { adenosine deaminase (NB4) }\end{array}$ & $\begin{array}{l}\text { Catalyzes the hydrolytic deamination of multiple adenosines to inosines in RNA. This } \\
\text { can result in diverse effects as a consequence of RNA modification. }\end{array}$ & $(5 / 7)$ & $\mathrm{Y}(1 / 1)$ & $x$ \\
\hline Q86V81 & ALYREF & THO complex subunit 4 & $\begin{array}{l}\text { Export adapter protein; functions in the export of spliced and unspliced mRNAs from } \\
\text { the nucleus and mRNA processing. }\end{array}$ & $(2 / 2)$ & $\mathrm{Y}(2 / 2)$ & $x$ \\
\hline Q9UIG0 & $B A Z 1 B$ & Tyrosine-protein kinase BAZ1B & $\begin{array}{c}\begin{array}{c}\text { Chromatin remodeling factor; involved in the promoting RNA polymerase (pol I, pol II, } \\
\text { and pol III) activity. }\end{array}\end{array}$ & $(11 / 12)$ & $\mathrm{Y}(3 / 4)$ & \\
\hline P17844 & $D D X 5$ & $\begin{array}{l}\text { Probable ATP-dependent RNA helicase } \\
\text { DDX5 }\end{array}$ & RNA helicase; involved in alternate pre-mRNA splicing; & $(1 / 4)$ & $\mathrm{Y}(1 / 3)$ & \\
\hline Q92841 & DDX17 & $\begin{array}{l}\text { Probable ATP-dependent RNA helicase } \\
\text { DDX17 }\end{array}$ & $\begin{array}{l}\text { RNA helicase; involved in RNA splicing, alternative RNA splicing, alteration of RNA } \\
\text { secondary structure; involved in rRNA and miRNA processing; a transcriptional } \\
\text { coactivator. }\end{array}$ & $(6 / 7)$ & $\mathrm{Y}(3 / 3)$ & \\
\hline Q9NR30 & DDX21 & Nucleolar RNA helicase 2 & $\begin{array}{l}\text { RNA helicase that senses the status of RNA pol I and RNA pol II activity; binds rRNAs, } \\
\text { snoRNAs, and mRNAs; influences RNA pol II transcription; binds dsRNA and acts as } \\
\text { a sensor for cytoplasmic dsRNA; activates inflammatory cascade. }\end{array}$ & $(3 / 4)$ & $\mathrm{N}$ & \\
\hline Q08211 & DHX9 & ATP-dependent RNA helicase A & $\begin{array}{l}\text { RNA-DNA helicase with role in DNA replication, RNA transcription, translation, and } \\
\text { RNA silencing; hnRNP actin binding. Transcriptional activator; mediates MYC mRNA } \\
\text { stability: Interacts with RELA, IGFBP1, CREB-BP. Involved in viral infection and } \\
\text { inflammasome activation; known substrate for EIF2AK2 (PKR). }\end{array}$ & $(7 / 9)$ & $\mathrm{N}$ & \\
\hline $\mathrm{O} 43143$ & DHX15 & $\begin{array}{c}\text { Pre-mRNA-splicing factor } \\
\text { ATP-dependent RNA helicase DHX15 }\end{array}$ & $\begin{array}{l}\text { RNA helicase; pre-mRNA splicing factor involved in the disassembly of the } \\
\text { spliceosome. }\end{array}$ & $(3 / 4)$ & $\mathrm{Y}(1 / 1)$ & \\
\hline Q99848 & EBNA1BP2 & Probable rRNA-processing protein EBP2 & $\begin{array}{l}\text { Required for the processing of the } 27 \mathrm{~S} \text { pre-rRNA; interacts with Ebstein-Barr virus } \\
\text { (EBV) EBNA1 protein; required for stable EBV episome segregation }\end{array}$ & $(1 / 1)$ & $\mathrm{N}$ & \\
\hline P68104 & EEF1A1 & Elongation factor 1-alpha 1 & $\begin{array}{l}\text { Promotes the GTP-dependent binding of the aminoacetyl-tRNA to the A site of the } \\
\text { ribosome. }\end{array}$ & $(1 / 1)$ & $\mathrm{N}$ & \\
\hline P05198 & EIF2S1 & $\begin{array}{c}\text { Eukaryotic translation initiation factor } 2 \\
\text { subunit } 1\end{array}$ & $\begin{array}{l}\text { Alpha subunit of the eIF2 translation initiation factor; forms the ternary complex with } \\
\text { GTP and the initiating tRNA. GTP hydrolysis catalyzes the formation of the } 80 \mathrm{~S} \\
\text { initiation complex. }\end{array}$ & $(1 / 1)$ & $\mathrm{Y}(1 / 1)$ & \\
\hline P20042 & EIF2S2 & $\begin{array}{c}\text { Eukaryotic translation initiation factor } 2 \\
\text { subunit } 2\end{array}$ & $\begin{array}{l}\text { Beta subunit of the eIF2 translation initiation factor; forms the ternary complex with } \\
\text { GTP and the initiating tRNA. GTP hydrolysis catalyzes the formation of the } 80 \mathrm{~S} \\
\text { initiation complex. }\end{array}$ & $(2 / 2)$ & $\mathrm{Y}(1 / 1)$ & \\
\hline O15371 & EIF3D & $\begin{array}{l}\text { Eukaryotic translation initiation factor } 3 \\
\text { subunit } D\end{array}$ & $\begin{array}{l}\text { mRNA CAP-binding component of the eIF3 complex; eIF3 is responsible for the } \\
\text { recruitment of other initiation factors to form the } 43 \text { S PIC; stimulates recruitment of } \\
\text { mRNA to the 43S PIC and codon scanning to localize the initiator AUG. }\end{array}$ & $(2 / 2)$ & $\mathrm{Y}(1 / 1)$ & \\
\hline Q99613 & EIF3C & $\begin{array}{l}\text { Eukaryotic translation initiation factor } 3 \\
\text { subunit } C\end{array}$ & $\begin{array}{l}\text { Component of the eIF3 complex; eIF3 is responsible for the recruitment of other } \\
\text { initiation factors to form the 43S PIC; stimulates recruitment of mRNA to the 43S PIC } \\
\text { and codon scanning to localize the initiator AUG. }\end{array}$ & $(1 / 2)$ & $\mathrm{N}$ & \\
\hline
\end{tabular}


Table 1. Cont.

\begin{tabular}{|c|c|c|c|c|c|c|}
\hline Acc \# & Gene Name & Name & Function & $\begin{array}{c}\text { AKT } \\
\text { pSites }\end{array}$ & $\begin{array}{l}\text { Known } \\
\text { Sites }\end{array}$ & $\begin{array}{l}\text { AKT/p70 } \\
\text { S6K Sub }\end{array}$ \\
\hline O60841 & EIF5B & $\begin{array}{l}\text { Eukaryotic translation initiation factor } \\
5 \mathrm{~B}\end{array}$ & $\begin{array}{l}\text { Translation GTPase that catalyzes the assembly of the } 80 \mathrm{~S} \text { translation initiation } \\
\text { complex. }\end{array}$ & $(4 / 4)$ & $\mathrm{Y}(2 / 2)$ & \\
\hline Q15717 & ELAVL1 & ELAV-like protein 1 & $\begin{array}{c}\text { Ribonucleoprotein complex; involved in 3' UTR AU-rich element (ARE) dependent } \\
\text { MYC, FOS, and IL3 stabilization; binds p53 mRNA to facilitate its export from the } \\
\text { nucleus. }\end{array}$ & $(1 / 2)$ & $\mathrm{Y}(1 / 1)$ & \\
\hline Q8IY81 & FTSJ3 & $\begin{array}{l}\text { Pre-rRNA 2'-O-ribose RNA } \\
\text { methyltransferase FTSJ3 }\end{array}$ & $\begin{array}{l}\text { RNA 2'-O-methyltransferase involved in early processing of } 18 \mathrm{~S} \text { rRNA and formation } \\
\text { of the } 40 \mathrm{~S} \text { ribosomal subunit; maturation of the } 5.8 \mathrm{~S} \text { rRNA. }\end{array}$ & $(4 / 4)$ & $\mathrm{Y}(1 / 1)$ & \\
\hline P35637 & FUS & RNA-binding protein FUS & $\begin{array}{l}\text { DNA/RNA -binding protein that influences transcription, RNA splicing, RNA } \\
\text { transport and DNA damage repair. }\end{array}$ & $(2 / 2)$ & $\mathrm{Y}(2 / 2)$ & \\
\hline P09651 & HNRNPA1 & $\begin{array}{l}\text { Heterogeneous nuclear } \\
\text { ribonucleoprotein A1 (NB4) }\end{array}$ & $\begin{array}{l}\text { Involved in pre-mRNA packaging into hnRNP; affects nuclear-cytoplasmic transport of } \\
\text { polyA RNA; affects splicing. }\end{array}$ & $(2 / 2)$ & $\mathrm{Y}(2 / 2)$ & $\mathrm{x}$ \\
\hline P52597 & HNRNPF & $\begin{array}{l}\text { Heterogeneous nuclear } \\
\text { ribonucleoprotein F }\end{array}$ & A component of the hnRNP complexes; involved in pre-mRNA processing. & $(3 / 4)$ & $\mathrm{Y}(3 / 3)$ & \\
\hline Q00839 & HNRNPU & $\begin{array}{l}\text { Heterogeneous nuclear } \\
\text { ribonucleoprotein } U\end{array}$ & $\begin{array}{l}\text { DNA/RNA-binding protein involved in RNA splicing, alternative splicing, and } \\
\text { stability; influences chromatin structure and suppresses RNA pol II-dependent } \\
\text { transcription. }\end{array}$ & $(2 / 4)(\mathrm{m})$ & $\mathrm{Y}(2 / 2)(\mathrm{m})$ & \\
\hline Q12905 & ILF2 & Interleukin enhancer-binding factor 2 & Functions as a heterodimer with ILF3 to regulate transcription of IL-2. & $(2 / 2)$ & $\mathrm{Y}(1 / 1)$ & \\
\hline Q07666 & KHDRBS1 & $\begin{array}{l}\text { KH domain-containing, RNA-binding, } \\
\text { signal transduction-associated protein } 1\end{array}$ & $\begin{array}{l}\text { RNA-binding protein that regulates nuclear-cytoplasmic export and alternative } \\
\text { splicing of mRNA. }\end{array}$ & $(3 / 3)$ & $\mathrm{Y}(1 / 1)$ & \\
\hline Q9NX58 & LYAR & Cell growth-regulating nucleolar protein & $\begin{array}{l}\text { Acts as a transcriptional regulator; functions in the processing of } 47 \mathrm{~S} \text { rRNA to } 18 \mathrm{~S} \text { and } \\
28 \mathrm{~S} \text { rRNAs; part of the } 90 \mathrm{~S}, 60 \mathrm{~S} \text {, and } 40 \mathrm{~S} \text { RNP complexes, but not polysomes; prevents } \\
\text { nucleolin self cleavage. }\end{array}$ & $(2 / 2)$ & $\mathrm{Y}(2 / 2)$ & \\
\hline P43243 & MATR3 & Matrin-3 & $\begin{array}{l}\text { May function in the nuclear retention of defective RNAs; involved in the activation of } \\
\text { the innate immune response. }\end{array}$ & $(8 / 9)$ & $\mathrm{Y}(8 / 8)$ & \\
\hline Q9BQG0 & МҮВВР1A & Myb-binding protein 1A & $\begin{array}{l}\text { DNA-binding protein that may activate or repress transcription; has a role in ribosome } \\
\text { biogenesis. }\end{array}$ & $(7 / 10)$ & $\mathrm{Y}(3 / 4)$ & \\
\hline Q9H0A0 & NAT10 & RNA cytidine acetyltransferase & $\begin{array}{l}\text { RNA cytidine acetyltransferase; modifies mRNA, } 18 \mathrm{~S} \text { rRNA, and tRNA; enhances } \\
\text { translation efficiency; may acetylate lysine in some proteins such as p53. }\end{array}$ & $(4 / 6)$ & $\mathrm{N}$ & \\
\hline P19338 & NCL & Nucleolin (NB4) & $\begin{array}{l}\text { RNA-binding protein that influence RNA pol I and pol II transcription; plays a role in } \\
\text { ribosome assembly }\end{array}$ & $(2 / 2)$ & $\mathrm{Y}(2 / 2)$ & \\
\hline Q15233 & NONO & $\begin{array}{l}\text { Non-POU domain-containing } \\
\text { octamer-binding protein }\end{array}$ & $\begin{array}{l}\text { DNA/RNA-binding protein involved in pre-mRNA splicing; plays a role in nuclear } \\
\text { retention of defective RNAs; involved in DNA double-strand break repair; serve a role } \\
\text { in ILF3 phosphorylation and innate immune response activation. }\end{array}$ & $(1 / 2)$ & $\mathrm{N}$ & \\
\hline P46087 & NOP2 & $\begin{array}{l}\text { Probable 28S rRNA (cytosine } \\
\text { (4447)-C(5))-methyltransferase NOP2 }\end{array}$ & $\begin{array}{l}\text { S-adenosyl-L-methionine-dependent methyltransferase that specifically methylates the } \\
\text { cytosine } 4447 \text { in } 28 \mathrm{r} \text { rRNA; involved in the assembly of the } 60 \mathrm{~S} \text { ribosomal subunit. }\end{array}$ & $(6 / 7)$ & $\mathrm{Y}(4 / 5)$ & \\
\hline
\end{tabular}


Table 1. Cont.

\begin{tabular}{|c|c|c|c|c|c|c|}
\hline Acc \# & Gene Name & Name & Function & $\begin{array}{c}\text { AKT } \\
\text { pSites }\end{array}$ & $\begin{array}{l}\text { Known } \\
\text { Sites }\end{array}$ & $\begin{array}{l}\text { AKT/p70 } \\
\text { S6K Sub }\end{array}$ \\
\hline O00567 & NOP56 & Nucleolar protein 56 & $\begin{array}{l}\text { Core component of box C/D small nucleolar ribonucleoprotein (snoRNP) particles. } \\
\text { Required for the biogenesis of box C/D snoRNAs; involved in the processing and } \\
\text { maturation of the } 60 \mathrm{~S} \text { ribosomal subunit. }\end{array}$ & $(4 / 5)$ & $Y(3 / 4)$ & \\
\hline P06748 & NPM1 & Nucleophosmin (NB4) & $\begin{array}{l}\text { Involved in cellular division, ribosome biogenesis, and ribosomal export; regulates p53 } \\
\text { and p14 } 14 \text { RFF ; enhances MYC transcriptional activity; involved in assembly and export } \\
\text { of the } 40 \text { S and } 60 \text { S ribosomal subunits; negatively regulates EIF2AK2 (PKR). }\end{array}$ & $(1 / 1)$ & $\mathrm{Y}(1 / 1)$ & \\
\hline P09874 & PARP1 & Poly [ADP-ribose] polymerase 1 & $\begin{array}{l}\text { DNA ribosyltransferase; promotes RNA pol II-dependent transcription; involved in } \\
\text { DNA repair. }\end{array}$ & $(2 / 2)$ & $\mathrm{N}$ & \\
\hline Q6P2Q9 & PRPF8 & Pre-mRNA-processing-splicing factor 8 & $\begin{array}{l}\text { RNA-binding protein that associates with both } 5^{\prime} \text { and } 3^{\prime} \text { splice sites to position the } \mathrm{U} 2 \text {, } \\
\text { U5, and U6 for spliceosome formation. }\end{array}$ & $(5 / 5)$ & $\mathrm{Y}(2 / 2)$ & \\
\hline Q9UMS4 & PRPF19 & Pre-mRNA-processing factor 19 & Ubiquitin protein ligase involved in pre-mRNA spliceosome assembly and DNA repair. & $(3 / 3)$ & $\mathrm{Y}(1 / 1)$ & $\mathrm{x}$ \\
\hline Q09028 & RBBP4 & Histone-binding protein RBBP4 & $\begin{array}{l}\text { Component of the chromatin assembly factor 1 (CAF-1) complex, which is required for } \\
\text { chromatin assembly following DNA replication and DNA repair; the core histone } \\
\text { deacetylase (HDAC) complex, which promotes histone deacetylation and consequent } \\
\text { transcriptional repression; the nucleosome remodeling and histone deacetylase } \\
\text { complex (the NuRD complex), which promotes transcriptional repression by histone } \\
\text { deacetylation and nucleosome remodeling; the PRC2/EED-EZH2 complex, which } \\
\text { promotes repression of homeotic genes during development; and the NURF } \\
\text { (nucleosome remodeling factor) complex. }\end{array}$ & $(1 / 10)(\mathrm{m})$ & $\mathrm{N}(\mathrm{m})$ & \\
\hline Q96PK6 & RBM14 & RNA-binding protein 14 & $\begin{array}{l}\text { Acts a transcriptional coactivator (isoform 1) or repressor (isoform 2); aids in the } \\
\text { activation of the innate immune response through ILF3 activation. }\end{array}$ & $(2 / 2)$ & $Y(2 / 2)$ & \\
\hline Q14498 & RBM39 & RNA-binding protein 39 & Transcriptional coactivator involved in RNA processing and splicing. & $(16 / 18)$ & $\mathrm{Y}(7 / 8)$ & \\
\hline P38159 & $R B M X$ & $\begin{array}{l}\text { RNA-binding motif protein, } \mathrm{X} \\
\text { chromosome }\end{array}$ & $\begin{array}{l}\text { RNA-binding protein that regulates pre- and post-transcriptional processes; involved } \\
\text { in RNA pol II transcription; involved in mRNA splicing and alternative splice site } \\
\text { selection. }\end{array}$ & $(5 / 9)$ & $Y(5 / 9)$ & \\
\hline P39023 & RPL3 & 60S ribosomal protein L3 (NB4) & Component of the large ribosomal subunit; binds $5 \mathrm{~S}$ rRNA. & $(3 / 3)$ & $\mathrm{Y}(1 / 3)$ & \\
\hline P36578 & RPL4 & 60S ribosomal protein L4 (NB4) & Structural component of the $60 \mathrm{~S}$ ribosomal subunit. & $(1 / 1)$ & $\mathrm{Y}(1 / 1)$ & \\
\hline P62917 & RPL8 & $60 \mathrm{~S}$ ribosomal protein $\mathrm{L} 8$ & Structural component of the $60 \mathrm{~S}$ ribosomal subunit; binds rRNA. & $(1 / 2)(\mathrm{m})$ & $\mathrm{Y}(0 / 1)(\mathrm{m})$ & \\
\hline P26373 & RPL13 & 60S ribosomal protein L13 (NB4) & Structural component of the $60 \mathrm{~S}$ ribosomal subunit. & $(4 / 5)$ & $\mathrm{Y}(3 / 4)$ & \\
\hline P40429 & RPL13A & $60 \mathrm{~S}$ ribosomal protein L13a (NB4) & $\begin{array}{l}\text { Associated with the ribosome but is not a required component; associates with } 3^{\prime} \text {-UTR } \\
\text { inflammatory mRNAs; interacts with eIF4G near the eIF3 binding site to prevent } 43 S \\
\text { ribosomal complex assembly. }\end{array}$ & $(1 / 1)$ & $\mathrm{N}$ & \\
\hline P84098 & RPL19 & 60S ribosomal protein L19 & Structural component of the $60 \mathrm{~S}$ ribosomal subunit; $5.8 \mathrm{~S}$ rRNA binding. & $(2 / 2)$ & $\mathrm{Y}(2 / 2)$ & \\
\hline P23396 & RPS3 & $40 \mathrm{~S}$ ribosomal protein S3 (NB4) & $\begin{array}{l}\text { Structural component of the } 40 \mathrm{~S} \text { ribosomal subunit; has endonuclease activity; } \\
\text { involved in DNA damage repair; interacts with MDM2 resulting in p53 stability. }\end{array}$ & $(1 / 1)$ & $\mathrm{Y}(1 / 1)$ & $x$ \\
\hline
\end{tabular}


Table 1. Cont.

\begin{tabular}{|c|c|c|c|c|c|c|}
\hline Acc \# & Gene Name & Name & Function & $\begin{array}{l}\text { AKT } \\
\text { pSites }\end{array}$ & $\begin{array}{l}\text { Known } \\
\text { Sites }\end{array}$ & $\begin{array}{l}\text { AKT/p70 } \\
\text { S6K Sub }\end{array}$ \\
\hline P62753 & RPS6 & $40 \mathrm{~S}$ ribosomal protein $\mathrm{S} 6$ & $\begin{array}{l}\text { Structural component of the } 40 \mathrm{~S} \text { ribosomal subunit; involved in rRNA processing; } \\
\text { involved in the selective translation of a certain class of mRNAs. }\end{array}$ & $(1 / 1)$ & $\mathrm{Y}(1 / 1)$ & \\
\hline P62081 & RPS7 & $40 \mathrm{~S}$ ribosomal protein $\mathrm{S} 7$ & $\begin{array}{l}\text { Structural component of the } 40 \text { S ribosomal subunit; involved in rRNA } \\
\text { processing/maturation; binds 3'-UTR and 5'-UTR of mRNA; involved in translation } \\
\text { initiation. }\end{array}$ & $(2 / 2)$ & $\mathrm{Y}(2 / 2)$ & \\
\hline P62241 & RPS8 & $40 \mathrm{~S}$ ribosomal protein $\mathrm{S} 8$ (NB4) & $\begin{array}{l}\text { Structural component of the 40S ribosomal subunit; involved in the maturation of the } \\
\qquad 18 \mathrm{~S} \text { rRNA. }\end{array}$ & $(1 / 1)$ & $\mathrm{N}$ & \\
\hline Q14684 & $R R P 1 B$ & $\begin{array}{l}\text { Ribosomal RNA processing protein } 1 \\
\text { homolog B }\end{array}$ & $\begin{array}{l}\text { Acts as a transcriptional coactivator; involved in mRNA splicing; promotes RNA pol II } \\
\text { transcription; involved in rRNA processing. }\end{array}$ & $(3 / 5)$ & $\mathrm{Y}(1 / 1)$ & \\
\hline O76021 & RSL1D1 & $\begin{array}{l}\text { Ribosomal L1 domain-containing } \\
\text { protein } 1\end{array}$ & Involved in large subunit rRNA processing/maturation; inhibits PTEN translation. & $(4 / 8)(\mathrm{m})$ & $\mathrm{Y}(2 / 4)(\mathrm{m})$ & \\
\hline Q9Y265 & RUVBL1 & RuvB-like 1 & $\begin{array}{l}\text { ATP-dependent DNA helicase; component of the NuA4 histone acetyltransferase } \\
\text { complex; binds to the TF-IID transcription complex; involved in H2A and H4 } \\
\text { acetylation and RNA pol II transcriptional activation; involved in C/D snoRNP } \\
\text { assembly; has a role in DNA repair; required for MYC oncogenesis. }\end{array}$ & $(3 / 6)(\mathrm{m})$ & $\mathrm{N}(\mathrm{m})$ & \\
\hline Q9Y230 & RUVBL2 & RuvB-like 2 & $\begin{array}{l}\text { ATP-dependent DNA helicase; component of the NuA4 histone acetyltransferase } \\
\text { complex; binds to the TF-IID transcription complex; involved in H2A and H4 } \\
\text { acetylation and RNA pol II transcriptional activation; involved in C/D snoRNP } \\
\text { assembly; has a role in DNA repair; binds } \beta \text {-catenin; required for MYC oncogenesis; } \\
\text { suppresses expression of ATF2 and endoplasmic reticulum stress response genes. }\end{array}$ & $(4 / 4)$ & $\mathrm{Y}(2 / 2)$ & \\
\hline Q13435 & SF3B2 & Splicing factor 3B subunit 2 & Part of the SF3B complex; involved in pre-mRNA splicing. & $(4 / 4)$ & $\mathrm{Y}(1 / 1)$ & \\
\hline Q15393 & SF3B3 & Splicing factor 3B subunit 3 (NB4) & Part of the SF3B complex; involved in pre-mRNA splicing. & $(2 / 2)$ & $\mathrm{N}$ & \\
\hline P23246 & $S F P Q$ & $\begin{array}{l}\text { Splicing factor, proline- and } \\
\text { glutamine-rich (NB4) }\end{array}$ & $\begin{array}{l}\text { DNA/RNA-binding protein; essential for spliceosome complex formation; enhances } \\
\text { RNA pol II transcription; involved in alternative splicing. }\end{array}$ & $(4 / 4)$ & $Y(3 / 3)$ & \\
\hline $\mathrm{O} 60264$ & SMARCA5 & $\begin{array}{l}\text { SWI/SNF-related matrix-associated } \\
\text { actin-dependent regulator of chromatin } \\
\text { subfamily A member } 5\end{array}$ & DNA-binding helicase; represses rDNA transcription. & $(4 / 4)$ & $\mathrm{N}$ & \\
\hline Q7KZF4 & SND1 & $\begin{array}{c}\text { Staphylococcal nuclease } \\
\text { domain-containing protein } 1 \text { (NB4) }\end{array}$ & Transcriptional coactivator of STAT5 and STAT6; mediates miRNA decay. & $(2 / 3)$ & $Y(1 / 1)$ & \\
\hline P08579 & SNRPB2 & U2 small nuclear ribonucleoprotein $B$ & Associated with the U2 snRNP involved in pre-mRNA splicing. & $(1 / 1)(\mathrm{m})$ & $\mathrm{Y}(1 / 1)(\mathrm{m})$ & \\
\hline Q07955 & SRSF1 & Serine/arginine-rich splicing factor 1 & $\begin{array}{l}\text { Involved in regulating the accuracy of splicing and alternative splicing by preventing } \\
\text { exon skipping; associates with U1 snRNP and U2AF; involved with mRNA } \\
\text { nuclear-cytoplasmic export. }\end{array}$ & $(13 / 14)$ & Y $(13 / 14)$ & \\
\hline
\end{tabular}


Table 1. Cont.

\begin{tabular}{|c|c|c|c|c|c|c|}
\hline Acc \# & Gene Name & Name & Function & $\begin{array}{c}\text { AKT } \\
\text { pSites }\end{array}$ & $\begin{array}{l}\text { Known } \\
\text { Sites }\end{array}$ & $\begin{array}{l}\text { AKT/p70 } \\
\text { S6K Sub }\end{array}$ \\
\hline Q01130 & SRSF2 & Serine/arginine-rich splicing factor 2 & $\begin{array}{l}\text { Required for pre-mRNA splicing; facilitates } \mathrm{U} 1 \text { and } \mathrm{U} 2 \mathrm{snRNP} \text { association with } \\
\text { pre-mRNA; links } 5^{\prime} \text { and } 3^{\prime} \text { splice site components } \mathrm{U} 1 \text { snRNP and U2AF, respectively; } \\
\text { regulates alternative splicing; facilitates mRNA export from the nucleus; acts as a } \\
\text { transcriptional corepressor. }\end{array}$ & $(27 / 27)$ & $\mathrm{Y}(12 / 12)$ & \\
\hline P12270 & $T P R$ & Nucleoprotein TPR & Component of the nuclear pore; involved in protein and RNA export/import. & $(9 / 9)$ & $\mathrm{Y}(2 / 2)$ & \\
\hline P08670 & VIM & Vimentin & Involved with LARP6 to stabilize certain mRNAs. & $(1 / 3)$ & $\mathrm{Y}(1 / 3)$ & $\mathrm{X}$ \\
\hline O95218 & ZRANB2 & $\begin{array}{c}\text { Zinc finger Ran-binding } \\
\text { domain-containing protein } 2\end{array}$ & Involved in alternative splicing by modifying $5^{\prime}$-splice site selection. & $(29 / 33)$ & $\mathrm{Y}(10 / 10)$ & \\
\hline
\end{tabular}

Proteins identified by AP-MS/MS analysis using either Spectrum Mill or Mascot platforms are listed in alphabetical order. Proteins followed by (NB4) are proteins that were also identified in AP-MS/MS analysis of nuclear proteins isolated from ATRA-treated NB4 cells and not untreated NB4 cells. Uniprot/Swissprot database accession number (Acc \#); number of sites matching the consensus epitope of the anti-AKT phosphosubstrate antibodies (K/R-x-K/R-x-x-S/T or R-x-x-S/T) over the number of potential AKT sites predicted by Scansite 4.0 at low stringency (AKT pSites; $\mathrm{m}=$ Scansite 4.0 predictions conducted at minimal stringency); number of potential AKT phosphorylation sites (Scansite 4.0 ) known to be phosphorylated (Phosphosite) that match the consensus epitope of the anti-AKT phosphosubstrate antibodies (K/R-x-K/R-x-x-S/T or R-x-x-S/T) over the number of potential AKT phosphorylation sites (Scansite 4.0) known to be phosphorylated (Phosphosite). Proteins that have been demonstrated to be substrates of AKT were marked with an " $X^{\prime \prime}$ (AKT sub). 


\section{Cell Cycle Regulators and Ribosomal Stress}

Coordination between cell division and proteins synthesis is imperative for cell survival; thus, it is not surprising that multiple regulators of the cell cycle also have a significant role in controlling ribosome biogenesis. Unphosphorylated retinoblastoma protein $(\mathrm{Rb})$ family members not only regulate the cell cycle by associating with the E2F transcription factor, but their hypophosphorylated forms also directly associate with UBF of the RNA pol I complex and TF-IIIB of the RNA pol III complex, inhibiting the synthesis of the $47 \mathrm{~S}$ and $5 \mathrm{~S}$ rRNAs, as well as the necessary snoRNAs and tRNAs (Figure $3 \mathrm{~A}$ ). Loss of $\mathrm{Rb}$ expression or hyperphosphorylation of $\mathrm{Rb}$, due to the activation of the cyclin-dependent kinase (CDK)-cyclin complex, results in the removal of this level of control [9,75-77]. Additionally, the smaller of the products of the ink $4 a$ tumor suppressor gene, $\mathrm{p} 14^{\mathrm{ARF}}$ (p19 ${ }^{\mathrm{ARF}}$ in mice) also associates with proteins of the RNA pol I complex affecting both 47S rRNA transcriptional initiation and termination [78]. More interestingly, $\mathrm{p} 14^{\mathrm{ARF}}$ has a significant role in regulating both rRNA processing, as well as p53-dependent transcription through its association with nucleophosmin (NPM1). NPM1 is a highly expressed nuclear phosphoprotein involved in diverse cellular processes (rRNA processing, ribosome protein nuclear import, ribosome assembly, and ribosome subunit nuclear export). NPM1 associates with diverse proteins, influencing their activity; among these are the p53 ubiquitinase MDM2 and the dsRNA-dependent inflammatory/stress activated kinase, PKR. When bound to NPM, these proteins are sequestered to the nucleus. Enhanced expression of p14 ${ }^{\mathrm{ARF}}$ results in its association with NPM and the formation of an MDM2 inhibitory complex, thus stabilizing p53 [79-83]. Similarly, the sequestration of PKR, by NPM, keeps it localized to the nucleus where its localization is associated with cell growth and DNA repair (Figure 3B). Garcia et al. reported that, following viral infection, enhanced expression of $\mathrm{p} 14^{\mathrm{ARF}}$ promoted its association with NPM, resulting in the release of PKR and the translocation of PKR to the cytoplasm, where it phosphorylates eIF2 $\alpha$, resulting in the inhibition of protein synthesis (see below) [84].

The p53 transcription factor is a master regulator of the cell. Most of the genes induced by p53 are involved in cell cycle regulation (arrest) and apoptosis; therefore, stimulation of p53 leads to cell cycle arrest and repair or subsequent cell death in most cases. In addition, p53 shares the stage with two closely related family members, p63 and p73. These family members may cooperate with or antagonize one another, depending on the promoter and the gene in question [85]. Approximately $50 \%$ of human tumors contain mutant p53. These mutations are known to affect the transactivation capacity of p53, p53 stability, and the ability of p53 to interact with additional cofactors $[9,85]$.

The status of p53 is also extremely important in the regulation of ribosome biogenesis. The association of p53 with SL-1 complex of RNA pol I or TF-IIIB of the RNA pol III complex results in transcriptional repression of these rRNA, tRNA, and snoRNA genes. The interaction of p53 with RNA pol II-dependent promoters can either stimulate or repress their transcription $[9,86,87]$. As stated above, p53 protein levels are chiefly regulated at the level of protein stability. The E3 ubiquitin ligase MDM2 associates with p53 and ubiquitinates it, thereby targeting it for degradation by the proteosome. Interestingly, p53 binding of the $m d m 2$ gene stimulates the synthesis of its transcript, thus p53 can autoregulate its expression through the induction of MDM2. The mechanisms that regulate ribosome biogenesis have taken advantage of the MDM2-p53 relationship as a checkpoint for ribosomal stress. Alterations in the levels of proteins required for rRNA synthesis, processing, and transport can influence the MDM2-p53 interaction $[79,88]$. Thus, alterations that may impinge on the early steps of ribosomal biogenesis also influence p53 stability, favoring the accumulation of p53. Among these proteins are NPM1 (see above) and nucleostemin (NS). Overexpression of NS causes its accumulation in the nucleoplasm and its association with MDM2 via interaction of the coiled-coiled domains of NS with the acidic domain of MDM2, thus inhibiting p53 ubiquitination and enhancing p53 stability. In contrast, depletion of NS activates p53 through the ribosomal protein pathway [79,89]. 
A

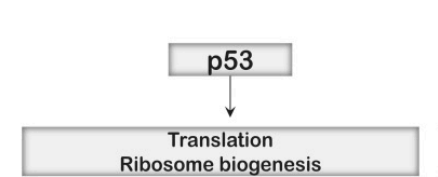

Ribosome biogenesis
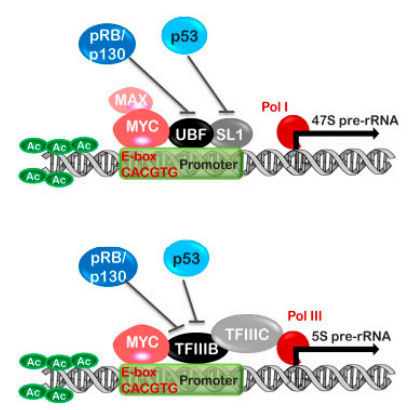

B

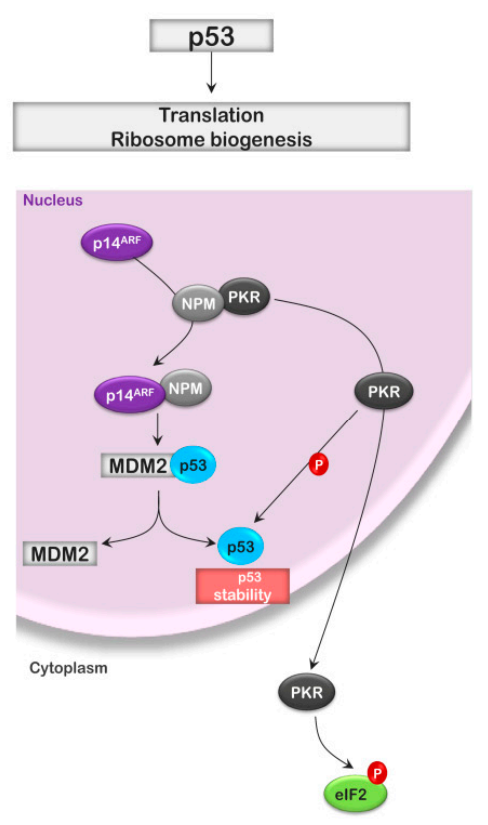

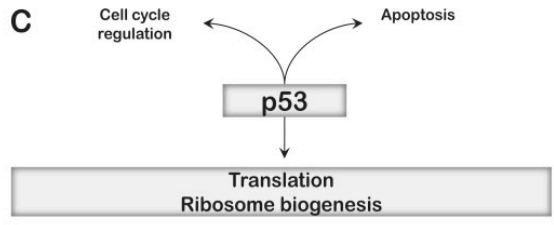

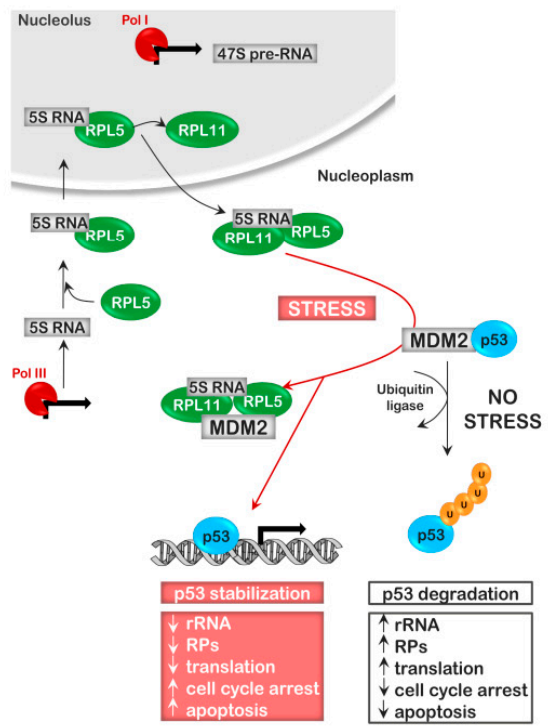

Figure 3. Regulation of ribosome biogenesis by cell cycle regulators. (A) The cell cycle regulators/tumor suppressors $\mathrm{pRb} / \mathrm{p} 130$ family and $\mathrm{p} 53$ regulate ribosome biogenesis by suppressing rDNA transcription initiation. (B) The tumor suppressor $\mathrm{p} 14^{\mathrm{ARF}}$, an alternate open reading frame of the $\mathrm{p} 16^{\mathrm{INK} 4 \mathrm{~A}}$ gene, regulates ribosome biogenesis and translation initiation through its interaction with NPM1 and MDM2, resulting in p53 stability and transactivation and eIF2 $\alpha$ phosphorylation. (C) Faulty assembly of ribosomal proteins (RPS and RPL) result in elevated levels of the pre-assembly RNP complex 5S RNP (RPL5-RPL11-5S rRNA), which binds to MDM2 resulting in p53 stability and transactivation. Additional RPSs and RPLs have been reported to bind MDM2 as well, resulting in the same effects on $\mathrm{p} 53$.

Additionally, the accumulation of rRNAs must match the level of rRNA processing protein complexes, which must match the synthesis of ribosomal proteins to be incorporated into the assembling ribosome, which must match the transport/chaperone proteins available. A certain amount of leeway must be inherent in the system and controlled or "tweaked" through transient activation stimulation of key signal transduction pathways. The system must also have the ability to alter the assembly of the ribosome to favor the translation of certain mRNAs over others when necessary for the cell. The obvious disproportion of the necessary RNA or protein intermediates results in the stimulation of p53 transcriptional activity, arresting the process of ribosome biogenesis. This safety switch for the organism impedes the production of ribosomes that possess altered activity, which could be deleterious to the organism (constitutive p53 activity can also contribute to disease-see below). Several ribosomal proteins are known to bind to MDM2 and inhibit its activity toward p53; these include RPS3, RPS7, RPL5, RPL11, and RPL23 (Figure 3C) [79,88].

The ribosome proteins are produced in excess in the cytoplasm. The stability of these proteins is dependent on their interaction with chaperones and nuclear import proteins. Those RPs not associated with chaperones and directed to the nucleus for ribosome assembly are quickly degraded by the ubiquitin proteosome complex (UPC). Thus, free nucleolar/nucleoplasm accumulation of these RPs would signal a failure in the maturation process of the $40 \mathrm{~S}$ and $60 \mathrm{~S}$ subunits and stimulate p53. One of the more interesting complexes is the RPL5-RPL11-5S rRNA (5S RNP). This complex, which has an early and critical role in rRNA processing, is an early sentinel for defects in ribosome biogenesis. Bursac et al. 
and Sloan et al. demonstrated that RPL5-RPL11-5S rRNA accumulation and association with MDM2 could take place in both the nucleolus and nucleoplasm [90,91]. Interestingly, the RPL5-RPL11-5SRNP complex is also likely responsible for p53 accumulation in response to the deficiency of many of the additional ribosomal proteins that do not directly interact with MDM2 (Figure 3C).

\section{EIF2 $\alpha$ Regulation and Translation Initiation: The PKR Story}

The ultimate goal of ribosome biogenesis is to produce ribosomes capable of accurately and successfully translating mRNAs into protein. Like ribosome biogenesis, the process of translation has a rate-limiting step, which is initiation; therefore, in addition to the eIF4F translation initiation complex, which is under the control of the AKT-mTOR and RAS-RAF-MAPK pathways, two additional initiation factors represent major points of translation control, eIF2 and eIF2B. These complexes bare both the GTP and the Met-tRNA necessary for pre-initiation complex (PIC) formation and translation initiation, as well as the proteins for the GDP to GTP exchange required to initiate the next round of translation [92-94]. Regulation of eIF2 is via the $\alpha$-subunit (eIF2 $\alpha$ ) and is probably the best understood mechanism regulating translation initiation. One of four different kinases (PKR, PERK, GCN2, or HRI) leads to the phosphorylation of eIF2 $\alpha$. Phosphorylation of eIF2 $\alpha$ on Ser51 results in eIF2 being locked in the GDP bound state with eIF2B, unable to catalyze the initiation of protein synthesis. As the eIF2 complex is limited compared to eIF2B, it does not take much phosphorylated eIF $2 \alpha$ to soon result in a complete block of general translation. Although each of these kinases phosphorylates eIF2 $\alpha$ on the same serine residue, they do so in response to differing stresses [56,95]. The PKR-like endoplasmic reticulum kinase (PERK) is mainly activated following ER stress, as part of the unfolded protein response (UPR) and has been shown in mice to be inhibited by AKT1-dependent phosphorylation [96-98]. The general control nonderepressable-2 (GCN2) is part of the nutrient sensing pathway and responds to amino acid starvation; lack of amino acids results in uncharged tRNAs, which stimulate GCN2 kinase activation [99]. Heme-regulated eukaryotic initiation factor-2-alpha kinase (HRI), which is expressed mainly in cells of erythroid lineage and the first of the eIF2 $\alpha$ kinases to be identified, is activated in response to low heme concentrations [100]. The double-strand RNA-dependent kinase PKR, on the other hand, is activated in response to the most diverse types of stresses; among these are: viral infection, dsRNA, peroxidation, mitochondrial stress, DNA damage, ER stress, inflammatory cytokines, growth factor deprivation, and Toll-like receptor activation [101,102]. Together, these kinases form a network that can regulate translation initiation under a myriad of stress conditions [103-105]. Interestingly, while each of these kinases can be found in the cytoplasm, PKR is the only eIF2 $\alpha$ kinase that is also present in the nucleolus and nucleoplasm [56,106].

From prokaryotes to mammals, ribosome biogenesis and subsequent translation are highly regulated by the surrounding environment to limit energy expenditure under conditions that are unfavorable for growth, as well as limit the possibility of producing mutant proteins $[107,108]$. While phosphorylation of eIF2 $\alpha$ was long thought to be strictly pro-apoptotic, this is not the case. Phosphorylation of eIF2 $\alpha$ results in a shut-down of general CAP-dependent translation but, at the same time, it allows for efficient translation of upstream open reading frames (uORFs) in particular mRNAs that contain complex secondary structure at the $5^{\prime}$ end and an IRES element upstream [109-111]. Short-term inhibition of general translation through eIF $2 \alpha$ phosphorylation establishes a pro-survival state by allowing for cellular repair and time for the cell to adjust following a particular stress [112]. If this stress cannot be resolved and general translation remains inhibited, the cell will likely die through apoptotic means; thus, a coordinated interaction between the eIF2 $\alpha$ kinases and the AKT-mTOR-p70 S6K pathway must be present. In contrast, under other conditions, the phosphorylation of eIF $2 \alpha$ has been shown to inhibit IRES-mediated translation [113]. These differences may be due, in part, to the presence of specific regulator proteins that differ between IRES elements and are, therefore, specific to the being mRNAs translated (Figure 4). 


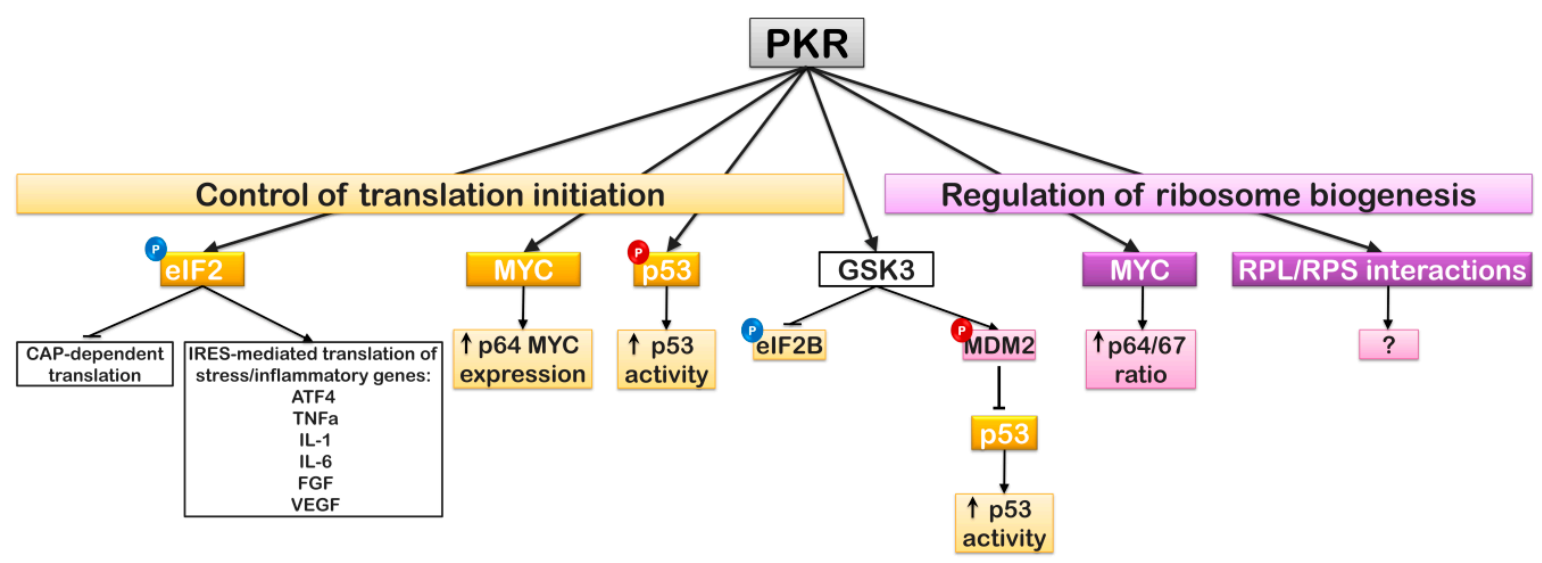

Figure 4. PKR regulates both translation initiation and ribosome biogenesis. The diverse points that PKR regulates in ribosome biogenesis and translation initiation are indicated. PKR regulates general CAP-dependent translation initiation and favors alternative translation initiation (ex., IRES) through the phosphorylation of eIF $\alpha$ or the modulation of GSK3 $\alpha / \beta$ phosphorylation by phosphatases. Regulation of ribosome biogenesis is through PKR-mediated effects on p53 stability and MYC isoform expression. PKR likely also influences a number of additional proteins critical to ribosome biogenesis with which it interacts in the nucleus, including diverse ribosomal proteins. Phosphorylation (P) marked in red represent phosphorylations that enhance the activity of the recipient protein; phosphorylations in blue represent phosphorylations that are inhibitory to the recipient protein.

Many of the mRNAs translated under conditions where eIF2 $\alpha$ is phosphorylated encode inflammatory cytokines such as TNF $\alpha$, IL-1, FGF, VEGF, IL-6; or transcription factors, such as the cyclic AMP-dependent transcription factor, ATF4 [114-119]. Significantly, prolonged expression of each of these inflammatory mediators is associated with angiogenesis and tumor progression. ATF4 leads to increased synthesis of ATF3, which was shown to be a significant factor in low-risk MDS [120]. This aspect of chronic inflammation is noteworthy as ATF3 is considered a pro-apoptotic transcription factor. The anti-apoptotic effect mediated by PI3K-AKT-mTOR pathway inhibition in colorectal cancer was correlated to enhanced ATF3 expression [121]. In contrast, several lines of evidence argue against ATF3 being strictly pro-apoptotic. Ectopic overexpression of ATF3 in breast tissue led to breast carcinoma in mice [122]. Moreover, ATF3 was found to be highly overexpressed in classic Hodgkin's lymphoma and contributes to the progression of this disease [123]. Whether constitutive overexpression of inflammatory cytokines like ATF4 is a secondary characteristic of these tumors, due to a ribosomal stress response that favors IRES-mediated translation or due to unrelated events has not been determined [56].

Phosphorylation of eIF2 $\alpha$ also favors translation of the full-length isoforms of the CAAT-enhancer binding proteins, $\mathrm{C} / \mathrm{EBP} \alpha$ and $\mathrm{C} / \mathrm{EBP} \beta$, which are both critical to hematopoietic development and differentiation [124]. Two isoforms of $\mathrm{C} / \mathrm{EBP} \alpha$ have been observed in cells, a full-length protein of approximately $40 \mathrm{kDa}(\mathrm{p} 42)$ and a truncated protein of about $30 \mathrm{kDa}$ (p30) [125]. While both p42 and p30 $\mathrm{C} / \mathrm{EBP} \alpha$ can interact with additional transcription factors, only $\mathrm{p} 42$ contains the entire transactivation domain [125]. Targeted deletion of C/EBP $\alpha$ in mice results in the inhibition of myeloid differentiation with subsequent blast accumulation $[125,126]$. Therefore, it is not surprising that $\mathrm{C} / \mathrm{EBP} \alpha$ has been found to be mutated or repressed in several hematologic malignancies where blast accumulation is a factor $[125,127,128]$. Interestingly, $\mathrm{p} 30 \mathrm{C} / \mathrm{EBP} \alpha$ can regulate the expression/accumulation of $\mathrm{p} 42 \mathrm{C} / \mathrm{EBP} \alpha$ through Ubc9 ubiquitin ligase-mediate ubiquitination of $\mathrm{p} 42 \mathrm{C} / \mathrm{EBP} \alpha$, resulting in $\mathrm{p} 42$ degradation; thus, blocking differentiation in CD34+ hematopoietic stem cells, favoring self-renewal $[56,129]$.

C/EBP $\beta$ is expressed as one of three forms: $p 38, p 33$, and p20, and in many ways is similar to $\mathrm{C} / \mathrm{EBP} \alpha$ [125]. But, whereas the loss of $\mathrm{C} / \mathrm{EBP} \alpha$ transcriptional activity is associated with tumorigenesis, loss of $\mathrm{C} / \mathrm{EBP} \beta$ is not $[56,125,130,131]$. 
Similarly, PKR is also known to regulate the expression of MYC. Diverse groups have demonstrated that PKR influences the expression of $c-m y c$ through the stimulation of the transcription factors nuclear factor (NF)- $\mathrm{kB}$ and signal transducers and activators of transcription (STAT) $[132,133]$. Blalock et al. demonstrated that pharmacological inhibition of PKR activity in an acute lymphoblastic leukemia cell line, where AKT activation was constitutively-active, resulted in enhanced expression of MYC. Not only did inhibition of PKR kinase activity enhance MYC expression, but it also influenced the isoform expression of MYC. Overexpression of PKR expression was shown to favor p64 MYC expression while siRNA-mediated knock-down of PKR favored p67 MYC expression [39]. The p64 isoform of MYC is initiated from a standard AUG start codon; in contrast, the $\mathrm{p} 67$ isoform is produced from a non-canonical CUG start codon and encodes an additional 15 amino acids at the amino terminus. Both p64 and p67 target E-box sites in MYC responsive promoters, but p67 can also target C/EBP elements, thus leading to the transcription of an additional set of responsive genes [39,40]. It has been suggested that the ratio p64/p67 dictates whether MYC expression favors growth and proliferation or stimulates the expression of pro-apoptotic factors, with p64 favoring proliferation and p67 favoring growth arrest $[39,40]$. This might suggest that the loss of PKR may stimulate a feedback control through MYC isoform expression to limit growth and proliferation of cells that do not have the necessary safeguards in place to monitor translation initiation (Figure 4).

The glycogen synthase kinase (GSK)-3 $\beta$, which is inhibited by AKT under growth conditions but whose activity can be stimulated by the eIF $2 \alpha$ kinases PKR and PERK through the action of phosphatases, phosphorylates diverse targets to inhibit growth and energy storage programs. Data from both hematological and neuronal models, in which AKT was constitutively-active, as a result of PTEN deletion, demonstrated that the inhibition of PKR in this genetic background, leads to increased inhibitory phosphorylation of GSK-3 $\alpha / \beta$ on Ser21/9, and eventual cell cycle arrest $[134,135]$. Among the targets of GSK-3 $\beta$ is the eIF2B $\varepsilon$-subunit. eIF2B serves to exchange GTP for GDP bound to the eIF2 complex [136]. The eIF2B GTP exchange factor is composed of $\alpha, \beta, \gamma, \delta$, and $\varepsilon$ subunits, of which the $82 \mathrm{kDa} \varepsilon$-subunit is the most critical to eIF2B regulation and is enzymatically responsible for the GDP to GTP exchange. The $\alpha-, \beta-$, and $\delta$-subunits associate with Ser51 phosphorylated eIF2 $\alpha$ and inhibit eIF2B $\varepsilon$ activity, locking eIF2B with eIF2 in the GDP-bound state while the $\gamma$-subunit, which is phosphorylated and regulated by casein kinase (CK)-II, promotes the activity of the $\varepsilon$-subunit. Phosphorylation of eIF2B $\varepsilon$ on Ser535 by GSK-3 $\beta$, following amino acid starvation, inhibits eIF2B activity $[56,136,137]$. For GSK-3 $\beta$ phosphorylation to occur, eIF2B $\varepsilon$ must first be phosphorylated on Ser540 by one of the DYRK family kinases. The phosphorylation of these residue is thought to result in translation of a set of mRNAs that is different from those translated when only eIF $2 \alpha$ is phosphorylated; thus, regulation of translation can give rise to proteins that are most efficiently translated under one of three (or more) different conditions $[56,137,138]$. Additional information on alternate translation can be found in the following reviews ([114,139-141]).

Stress signaling through PKR is also a critical component of p53 regulation. PKR directly phosphorylates Ser392 of p53, resulting in enhanced stability and transcriptional activity of p53. It has been observed that pharmacological inhibition of PKR in an active AKT background leads to the rapid degradation of p53 (unpublished results). Moreover, the activator of PKR, RAX/PACT, stimulates the sumoylation of p53 enhancing its activity, yet Baltzis et al. demonstrated that PKR and PERK lead to p53 degradation through GSK-3 $\alpha / \beta$-mediated phosphorylation and activation of MDM2. Under the conditions examined, GSK- $3 \alpha / \beta$ resulted in enhanced ubiquitination of $\mathrm{p} 53$ and its subsequent nuclear export and degradation [142]. As GSK-3 $\alpha / \beta$ was active in this study, it would stand to reason that a significant level AKT activity was not present in these cells under the conditions of the study. Thus, one might postulate that the fate of p53 relies on a balance between the eIF2 $\alpha$ kinases (PKR and PERK) and AKT-mTOR activation (Figure 4). This would actually make sense as under stress conditions where AKT-mTOR still favored ribosome biogenesis and translation, PKR (or PERK in the case of ER stress) would result in p53 stabilization. In contrast, under conditions where a stress or insult occurs in 
the absence of a growth-promoting signal through AKT-mTOR, it may not be advantageous for the stress response through the interested eIF $2 \alpha$ kinases to promote p53-dependent transcription.

Being associated with the $40 \mathrm{~S}$ subunit, $60 \mathrm{~S}$ subunit, $80 \mathrm{~S}$ PIC, and polysomes, PKR is in the perfect position to respond to any cellular stress and regulate translation [143]. With the presence of PKR in the nucleus and the recent finding that it is associated with diverse proteins involved in ribosome biogenesis, it would not be surprising if PKR has other direct roles in the mechanisms responsible for protein synthesis other than simply that of eIF $2 \alpha$ and p53 phosphorylation. A recent study by Blalock et al. reported that PKR isolated from nuclear lysates was associated with a number of ribosomal proteins of the $40 \mathrm{~S}$ and $60 \mathrm{~S}$ ribosomal subunits; the majority of which were found associated when PKR was active [39]. Treatment with a pharmacological inhibitor of PKR resulted in the dissociation of all but two of these RPs (RPS10 and RPS10-like) and the association of an additional four RPs (RPS19, RPS26, RPL23, and RPL36) (Figure 4). Interestingly, haplosufficiency of several of these proteins, RPS10, RPS19, and RPS26, is associated with Diamond-Blackfan Anemia (DBA; see below). Additional proteins found to associate with PKR were involved in nuclear protein import, rRNA synthesis/modification/processing, mRNA nuclear export, ribosome assembly, PIC assembly, MYC expression, and IRES-dependent translation. In all, approximately $60 \%$ of the proteins associated with PKR in the nucleus play a significant role in ribosome biogenesis and translation initiation (for a full list of the identified proteins, see Table 2). What was not determined in this study was which of the identified proteins was directly associated with PKR and/or a substrate of PKR; and if an associated protein did represent a substrate of PKR, what were the site(s) and significance of PKR-dependent phosphorylation of the protein [39]. 
Table 2. Biogenesis/mRNA processing-related proteins in complex with nuclear PKR.

\begin{tabular}{|c|c|c|c|c|}
\hline Acc \# & Gene Name & Description & Function & Involvement in Disease \\
\hline P55265 & $A D A R$ & $\begin{array}{l}\text { Double-stranded RNA-specific } \\
\text { adenosine deaminase (1) }\end{array}$ & $\begin{array}{l}\text { Catalyzes the hydrolytic deamination of multiple adenosines to inosines in RNA. This can result in diverse } \\
\text { effects as a consequence of RNA modification. }\end{array}$ & $\begin{array}{l}\text { Dyschromatosis hereditaria, } \\
\text { Aicardi-Goutieres syndrome } 6\end{array}$ \\
\hline Q8WYP5 & AHCTF1 & Protein ELYS & $\begin{array}{l}\text { Required for the assembly of a functional nuclear pore complex (NPC). The NPC is required for } \\
\text { nuclear-cytoplasmic transport of RNA species and ribonucleoproteins (RNP) complexes and vice versa for } \\
\text { the transport of ribosomal proteins (RPs); has effects on RNA pol II activity. }\end{array}$ & \\
\hline Q13838 & BAT1 & $\begin{array}{l}\text { Spliceosome RNA helicase } \\
\text { DDX39B }\end{array}$ & $\begin{array}{l}\text { Component of the THO subcomplex of the TREX complex that specifically associates with spliced mRNA; } \\
\text { has a role in the nuclear export of unspliced mRNAs. Weak RNA helicase activity that catalyzes the first } \\
\text { step in spliceosome assembly for the subsequent binding of the U2 snRNP. }\end{array}$ & \\
\hline Q14692 & BMS1 & $\begin{array}{l}\text { Ribosome biogenesis protein } \\
\text { BMS1 homolog }\end{array}$ & $\begin{array}{l}\text { Maturation of the 40S ribosomal subunit in the nucleolus; binds U3 snoRNA and may be required for the } \\
\text { maturation of rRNA. }\end{array}$ & Aplasia cutis congenita (ACC) \\
\hline Q9Y3Y2 & Clorf77 & $\begin{array}{l}\text { Chromatin target of PRMT1 } \\
\text { protein }\end{array}$ & $\begin{array}{l}\text { Associates with the methylsome complex to induce gene transcription; is a component of the TREX } \\
\text { complex; associates upstream of the exon junction complex (EJC) on spliced mRNAs and facilitates their } \\
\text { nuclear export. }\end{array}$ & \\
\hline Q9BRJ6 & C7orf50 & $\begin{array}{l}\text { Uncharacterized protein } \\
\text { C7orf50 }\end{array}$ & $\begin{array}{l}\text { Not reported. Has RNA binding ability; associates with multiple proteins involved in processing of } 27 \mathrm{~S} \text { and } \\
18 \mathrm{~S} \text { rRNAs. }\end{array}$ & \\
\hline O14646 & CHD1 & $\begin{array}{l}\text { Chromodomain-helicase- } \\
\text { DNA-binding protein } 1\end{array}$ & $\begin{array}{l}\text { Involved in chromatin remodeling; substrate recognition component of the transcription regulatory } \\
\text { histone acetylation (HAT) complex SAGA; regulates RNA polymerase I and II transcription. Associated } \\
\text { with diverse mRNA splicing complexes (FACT, PAF and U2 snRNP); blocks DNA replication. }\end{array}$ & $\begin{array}{l}\text { Pilarowski-Bjornsson syndrome } \\
\text { (PILBOS) }\end{array}$ \\
\hline P38432 & COIL & Coilin & $\begin{array}{l}\text { Major component of Cajal Bodies; involved in the function or assembly/disassembly of nucleoplasmic } \\
\text { snRNPs. }\end{array}$ & \\
\hline Q92499 & DDX1 & $\begin{array}{l}\text { ATP-dependent RNA helicase } \\
\text { DDX1 }\end{array}$ & $\begin{array}{l}\text { RNA helicase with activity toward RNA-RNA and RNA-DNA helices. Binds poly A mRNA and may be } \\
\text { involved in the processing and polyadenylation of the } 3^{\prime} \text {-end of mRNA; involved in tRNA splicing. Acts } \\
\text { as a sensor of dsRNA and is involved in the induction of inflammatory cytokines. }\end{array}$ & \\
\hline Q8TDD1 & DDX54 & $\begin{array}{l}\text { ATP-dependent RNA helicase } \\
\text { DDX54 }\end{array}$ & Represses the transcriptional activity of nuclear receptors. Involved in RNA processing. & \\
\hline Q08211 & DHX9 & $\begin{array}{l}\text { ATP-dependent RNA helicase A } \\
\text { (1) }\end{array}$ & $\begin{array}{l}\text { RNA-DNA helicase with role in DNA replication, RNA transcription, translation, and RNA silencing; } \\
\text { hnRNP actin binding. Transcriptional activator; mediates MYC mRNA stability: Interacts with RELA, } \\
\text { IGFBP1, CREB-BP. Involved in viral infection and inflammasome activation; known substrate for EIF2AK2 } \\
\text { (PKR). }\end{array}$ & \\
\hline Q8IY37 & DHX37 & $\begin{array}{l}\text { Probable ATP-dependent RNA } \\
\text { helicase DHX37 }\end{array}$ & Has a role in rRNA processing. & \\
\hline O60832 & $D K C 1$ & $\begin{array}{l}\text { H/ACA ribonucleoprotein } \\
\text { complex subunit } 4\end{array}$ & $\begin{array}{l}\text { Required for ribosome biogenesis and telomere maintenance; promotes cell to cell and cell to substratum } \\
\text { adhesion, increases the cell proliferation rate; catalytic unit of the H/ACA snoRNP complex which is } \\
\text { required for pseudouridylation of rRNA; required for correct processing/trafficking of TERC }\end{array}$ & $\begin{array}{l}\text { X-linked Dyskeratosis } \\
\text { Congenita (XDKC), } \\
\text { Hoyeraal-Hreidarsson } \\
\text { syndrome (HHS) }\end{array}$ \\
\hline Q99848 & EBNA1BP2 & $\begin{array}{l}\text { Probable rRNA-processing } \\
\text { protein EBP2 (1) }\end{array}$ & $\begin{array}{l}\text { Required for the processing of the 27S pre-rRNA; interacts with Ebstein-Barr virus (EBV) EBNA1 protein; } \\
\text { required for stable EBV episome segregation }\end{array}$ & \\
\hline
\end{tabular}


Table 2. Cont

\begin{tabular}{|c|c|c|c|c|}
\hline Acc \# & Gene Name & Description & Function & Involvement in Disease \\
\hline P19525 & EIF2AK2 & $\begin{array}{l}\text { Interferon-induced, } \\
\text { dsRNA-activated protein kinase }\end{array}$ & $\begin{array}{l}\text { dsRNA-binding kinase activated in response to diverse stresses; phosphorylates elF2 } \alpha \text { leading to } \\
\text { inhibition of general translation; activation may favor IRES-mediated translation; phosphorylates p53 to } \\
\text { stabilize it; alters MYC isoform expression. }\end{array}$ & $\begin{array}{l}\text { Elevated constitutive activity } \\
\text { associated with diverse } \\
\text { diseases. }\end{array}$ \\
\hline P38919 & EIF4A3 & $\begin{array}{l}\text { Eukaryotic initiation factor } \\
\qquad 4 \mathrm{~A}-\mathrm{III}\end{array}$ & $\begin{array}{l}\text { ATP-dependent RNA helicase; component of a splicing-dependent multiprotein exon junction complex } \\
\text { (EJC) deposited at splice junction on mRNAs; affects nuclear-cytoplasmic transport of mRNAs; enhances } \\
\text { translation of spliced mRNA. }\end{array}$ & $\begin{array}{l}\text { Richieri-Costa-Pereira } \\
\text { syndrome (RCPS) }\end{array}$ \\
\hline P56537 & EIF6 & $\begin{array}{l}\text { Eukaryotic translation initiation } \\
\text { factor } 6(1)\end{array}$ & $\begin{array}{l}\text { Binds to the } 60 \mathrm{~S} \text { ribosomal subunit and prevents its premature association with the } 40 \mathrm{~S} \text { ribosomal subunit } \\
\text { to form the } 80 \mathrm{~S} \text { initiation complex in the cytoplasm; affects } 60 \mathrm{~S} \text { ribosomal subunit export from the nucleus; } \\
\text { enhances the translation of certain transcription factor mRNAs (CEBP, ATF4); affects miRNA silencing of } \\
\text { mRNAs; controls the expression mitochondrial respiratory chain genes. }\end{array}$ & $\begin{array}{l}\text { High expression in colon } \\
\text { carcinoma }\end{array}$ \\
\hline Q15717 & ELAVL1 & ELAV-like protein 1 & $\begin{array}{l}\text { Ribonucleoprotein complex; involved in } 3^{\prime} \text { UTR AU-rich element (ARE) dependent MYC, FOS, and IL3 } \\
\text { stabilization; binds p53 mRNA to facilitate its export from the nucleus. }\end{array}$ & \\
\hline Q9BVP2 & GNL3 & $\begin{array}{l}\text { Guanine nucleotide-binding } \\
\text { protein-like } 3(1)\end{array}$ & Stabilizes MDM2 by preventing its ubiquitination, and proteasomal degradation. & \\
\hline O60812 & HNRNPCL1 & $\begin{array}{l}\text { Heterogeneous nuclear } \\
\text { ribonucleoprotein C-like 1 (1) }\end{array}$ & Ribonucleosome component affecting hnRNPs. & \\
\hline Q14103 & HNRNPD & $\begin{array}{l}\text { Heterogeneous nuclear } \\
\text { ribonucleoprotein D0 }\end{array}$ & $\begin{array}{l}\text { Component of the ribonucleosomes; binds } 3^{\prime} \text { AU-rich elements (AREs) of mRNA to destabilize transcripts, } \\
\text { binds ssDNA, and can act as a transcription factor; involved in coupled mRNA translation and turn-over. }\end{array}$ & \\
\hline P52272 & HNRNPM & $\begin{array}{l}\text { Heterogeneous nuclear } \\
\text { ribonucleoprotein } \mathrm{M}\end{array}$ & $\begin{array}{c}\text { Pre-mRNA binding protein; part of the spliceosome C complex; binds poly (G) and poly (U) stretches; may } \\
\text { affect signaling events leading to TNF } \alpha, \text { IL-1 } 1 \alpha \text {, IL6, and IL10. }\end{array}$ & \\
\hline P07910 & HNRPC & $\begin{array}{l}\text { Heterogeneous nuclear } \\
\text { ribonucleoproteins } \mathrm{C} 1 / \mathrm{C} 2 \text { (1) }\end{array}$ & $\begin{array}{l}\text { Mediates } 40 \mathrm{~S} \text { hnRNP particles assembly; binds } 5^{\prime} \text { and } 3^{\prime} \text { poly }(\mathrm{U}) \text { tracks of mRNA affecting their stability } \\
\text { and translation; may play a role in spliceosome assembly and influence splicing of mRNAs through early } \\
\text { association with pre-mRNA. }\end{array}$ & \\
\hline O14979 & $H N R P D L$ & $\begin{array}{l}\text { Heterogeneous nuclear } \\
\text { ribonucleoprotein D-like }\end{array}$ & $\begin{array}{l}\text { Transcriptional regulator of DNA; promotes transcriptional activation in differentiated myotubes; binds } 3^{\prime} \\
\text { UTR AU-rich elements (AREs) in mRNAs; RNA processing. }\end{array}$ & $\begin{array}{l}\text { Muscular dystrophy, } \\
\text { limb-girdle, autosomal } \\
\text { dominant } 3 \text { (LGMDD3) }\end{array}$ \\
\hline Q12906 & ILF3 & $\begin{array}{l}\text { Interleukin enhancer-binding } \\
\text { factor } 3\end{array}$ & $\begin{array}{l}\text { Involved in biogenesis of circular RNAs from back splicing by binding regulatory elements flanking } \\
\text { introns; binds AU-rich element of target RNAs; participates in diverse transcriptional and } \\
\text { post-transcriptional event; is an EIF2AK2 (PKR) substrate; phosphorylation results in ILF3 release of } \\
\text { circular RNAs. }\end{array}$ & \\
\hline P52292 & KPNA2 & Importin subunit alpha-2 & Functions in nuclear protein import as an adapter protein for nuclear receptor KPNB1; Ran-dependent. & \\
\hline O00629 & KPNA4 & Importin subunit alpha-4 & Functions in nuclear protein import as an adapter protein for nuclear receptor KPNB1; Ran-dependent. & \\
\hline Q13601 & KRR1 & $\begin{array}{l}\text { KRR1 small subunit processome } \\
\text { component homolog }\end{array}$ & Involved in nucleolar processing of pre-18S ribosomal RNA and $40 \mathrm{~S}$ ribosome biogenesis. & \\
\hline Q6PKG0 & LARP1 & La-related protein $1(1)$ & $\begin{array}{l}\text { Regulates the translation of specific mRNAs downstream of mTORC1 signaling; when unphosphorylated } \\
\text { associates with 5' UTRs of 5'TOP mRNAs blocking translation by inhibiting eIF4G binding; } \\
\text { phoshorylation by mTORC1 results in dissociation from 5 5'TOP mRNAs favoring their translation; under } \\
\text { favorable growth conditions, association with } 3^{\prime} \mathrm{UTR} \text { of most mRNAs favors their translation. }\end{array}$ & \\
\hline
\end{tabular}


Table 2. Cont

\begin{tabular}{|c|c|c|c|c|}
\hline Acc \# & Gene Name & Description & Function & Involvement in Disease \\
\hline Q9NX58 & LYAR & $\begin{array}{l}\text { Cell growth-regulating } \\
\text { nucleolar protein (1) }\end{array}$ & $\begin{array}{l}\text { Acts as a transcriptional regulator; functions in the processing of } 47 \mathrm{~S} \text { rRNA to } 18 \mathrm{~S} \text { and } 28 \mathrm{~S} \text { rRNAs; part of } \\
\text { the } 90 \mathrm{~S}, 60 \mathrm{~S} \text {, and } 40 \mathrm{~S} \text { RNP complexes, but not polysomes; prevents nucleolin self cleavage. }\end{array}$ & \\
\hline O95251 & MYST2 & Histone acetyltransferase KAT7 & $\begin{array}{l}\text { HBO1 (HAT) complex which has H4-specific acetyltransferase activity, reduced activity toward H3; } \\
\text { positive regulator of RNA pol II; promotes p53 transcription. }\end{array}$ & \\
\hline Q8NEJ9 & NGND & Neuroguidin & $\begin{array}{l}\text { Translational repression of cytoplasmic polyA element containing transcripts; involved in the maturation } \\
\text { of 40S subunits rRNA. }\end{array}$ & \\
\hline Q8WTT2 & NOC3L & $\begin{array}{l}\text { Nucleolar complex protein } 3 \\
\text { homolog (1) }\end{array}$ & Specifically influences RNA pol II transcriptional activity. & \\
\hline Q9UGY1 & NOL12 & Nucleolar protein 12 & Binds $28 \mathrm{~S}$ rRNA; involved in rRNA processing; stabilizes the nucleus; inhibits apoptosis. & \\
\hline P46087 & NOP2 & $\begin{array}{l}\text { Putative ribosomal RNA } \\
\text { methyltransferase NOP2 (1) }\end{array}$ & $\begin{array}{l}\text { S-adenosyl-L-methionine dependent methyltransferase that catalyzes the methylation of cytosine } 4447 \text { in } \\
\text { 28S rRNA; affects 60S subunit assembly; regulates RNA pol II-mediated transcription; associated with cell } \\
\text { proliferation. }\end{array}$ & \\
\hline P06748 & NPM1 & Nucleophosmin (1) & $\begin{array}{l}\text { Involved in cellular division, ribosome biogenesis and ribosomal export; regulates p53 and p14 }{ }^{\mathrm{ARF}} \text {; } \\
\text { enhances MYC transcriptional activity; involved in assembly and export of the } 40 \mathrm{~S} \text { and } 60 \mathrm{~S} \text { ribosomal } \\
\text { subunits; negatively regulates EIF2AK2 (PKR). }\end{array}$ & $\begin{array}{l}\text { Myelodysplastic syndromes } \\
\text { (MDS) Leukemia, } \\
\text { non-Hodgkin's lymphoma }\end{array}$ \\
\hline Q9UQ80 & PA2G4 & $\begin{array}{l}\text { Proliferation-associated protein } \\
\qquad 2 \mathrm{G} 4\end{array}$ & $\begin{array}{l}\text { Inhibits transcription of some E2F1-regulated promoters by sequestering the HAT complex; associates } \\
\text { with } 28 \mathrm{~S} 18 \mathrm{~S} \text { and } 5.8 \mathrm{~S} \text { rRNAs and U3 snRNAs; involved in the intermediate and late stages of rRNA } \\
\text { maturation; mediates cap-independent translation of specific viral IRES containing mRNAs. }\end{array}$ & \\
\hline Q9BY77 & POLDIP3 & $\begin{array}{l}\text { Polymerase delta-interacting } \\
\text { protein } 3\end{array}$ & $\begin{array}{l}\text { Positive regulation of translation; recruits p70 S6 kinase to the ribosome; involved in mRNA export; } \\
\text { associates with spliced RNA-protein complexes favoring translation of spliced mRNAs. }\end{array}$ & \\
\hline P62136 & PPP1CA & $\begin{array}{l}\text { Serine/threonine-protein } \\
\text { phosphatase PP1-alpha catalytic } \\
\text { subunit }\end{array}$ & $\begin{array}{l}\text { Protein phosphatase } 1 \text { (PP1) is essential for cell division, and participates in the regulation of glycogen } \\
\text { metabolism, muscle contractility, and protein synthesis, cell migration; dephosphorylates a variety of } \\
\text { substrates including eIF2 } \alpha .\end{array}$ & \\
\hline P63244 & RACK1 & $\begin{array}{l}\text { Receptor of activated protein } \\
\text { kinase } \mathrm{C} 1\end{array}$ & $\begin{array}{l}\text { Scaffolding protein; binds to and stabilizes activated protein kinase } \mathrm{C} \text { (PKC), increasing PKC-mediated } \\
\text { phosphorylation of EIF6 causing its dissociation from the } 60 \text { S ribosomal subunit; inhibits Src kinases, } \\
\text { prolongs } \mathrm{G}_{1} / \mathrm{G}_{0} \text {, inhibits Wnt signaling, promotes BAX oligomerization; binds HIV NEF1. }\end{array}$ & $\begin{array}{l}\text { Elevated expression in } \\
\text { hepatocellular carcinoma }\end{array}$ \\
\hline Q09028 & RBBP4 & Histone-binding protein RBBP4 & $\begin{array}{l}\text { Component of the chromatin assembly factor } 1 \text { (CAF-1) complex, which is required for chromatin assembly } \\
\text { following DNA replication and DNA repair; the core histone deacetylase (HDAC) complex, which } \\
\text { promotes histone deacetylation and consequent transcriptional repression; the nucleosome remodeling and } \\
\text { histone deacetylase complex (the NuRD complex), which promotes transcriptional repression by histone } \\
\text { deacetylation and nucleosome remodeling; the PRC2/EED-EZH2 complex, which promotes repression of } \\
\text { homeotic genes during development; and the NURF (nucleosome remodeling factor) complex. }\end{array}$ & \\
\hline P39023 & RPL3 & $60 \mathrm{~S}$ ribosomal protein L3 & Component of the large ribosomal subunit; binds 5S rRNA. & \\
\hline P27635 & RPL10 & $60 \mathrm{~S}$ ribosomal protein $\mathrm{L} 10$ & $\begin{array}{l}\text { Component of the 60S ribosomal subunit; may have an active role in translation initiation; has a role in the } \\
\text { negative regulation of RNA pol II. }\end{array}$ & Autism, X-linked 5 (AUTSX5) \\
\hline Q96L21 & RPL10L & $\begin{array}{l}60 \mathrm{~S} \text { ribosomal protein L10-like } \\
\text { (1) }\end{array}$ & $\begin{array}{l}\begin{array}{l}\text { Component of the } 60 \mathrm{~S} \text { ribosomal subunit; may play a role in compensating for the inactivated X-linked } \\
\text { gene during spermatogenesis. }\end{array}\end{array}$ & \\
\hline
\end{tabular}


Table 2. Cont.

\begin{tabular}{|c|c|c|c|c|}
\hline Acc \# & Gene Name & Description & Function & Involvement in Disease \\
\hline P35268 & RPL22 & $60 \mathrm{~S}$ ribosomal protein $\mathrm{L} 22$ & $\begin{array}{l}\text { Component of the 60S ribosomal subunit; may have a role in translation initiation; binds Ebstein-Barr } \\
\text { virus (EBV) EBER transcripts and heparin. }\end{array}$ & \\
\hline P62829 & RPL23 & $60 \mathrm{~S}$ ribosomal protein $\mathrm{L} 23$ & $\begin{array}{l}\text { Component of the 60S ribosomal subunit; associates with rRNA; negatively regulates RNA pol II } \\
\text { transcription; negative regulation of ubiquitin protein ligase activity; }\end{array}$ & \\
\hline P61254 & RPL26 & $60 \mathrm{~S}$ ribosomal protein L26 & $\begin{array}{l}\text { Component of the } 60 \mathrm{~S} \text { ribosomal subunit; involved in rRNA processing; involved in translation initiation; } \\
\text { involved in DNA damage response favoring p53-dependent transcription; associates with the 5' UTR of } \\
\text { mRNAs. }\end{array}$ & $\begin{array}{l}\text { Diamond-Blackfan anemia, } \\
\text { type } 11\end{array}$ \\
\hline P46776 & RPL27A & $60 \mathrm{~S}$ ribosomal protein $\mathrm{L} 27 \mathrm{a}$ & Component of the $60 \mathrm{~S}$ ribosomal subunit; involved in translation initiation; binds RNA. & \\
\hline P62910 & RPL32 & $60 \mathrm{~S}$ ribosomal protein L32 & Component of the $60 \mathrm{~S}$ ribosomal subunit; involved in translation initiation; binds RNA. & \\
\hline P49207 & RPL34 & $60 \mathrm{~S}$ ribosomal protein L34 & Component of the 60S ribosomal subunit; involved in translation initiation; binds RNA; binds cadherin. & \\
\hline P42766 & RPL35 & $60 \mathrm{~S}$ ribosomal protein L35 & $\begin{array}{l}\text { Component of the } 60 \mathrm{~S} \text { ribosomal subunit; involved in the maturation of the } 60 \mathrm{~S} \text { subunit rRNA; involved } \\
\text { in translation initiation; binds mRNA. }\end{array}$ & \\
\hline Q9Y3U8 & RPL36 & 60S ribosomal protein L36 & Component of the $60 \mathrm{~S}$ ribosomal subunit; involved in translation initiation; binds RNA. & \\
\hline P46783 & RPS10 & $40 \mathrm{~S}$ ribosomal protein $\mathrm{S} 10$ & Component of the $40 \mathrm{~S}$ ribosomal subunit; involved in translation initiation; binds RNA. & $\begin{array}{l}\text { Diamond-Blackfan anemia type } \\
9\end{array}$ \\
\hline Q9NQ39 & RPS10L & $\begin{array}{l}\text { Putative 40S ribosomal protein } \\
\text { S10-like }\end{array}$ & Component of the $40 \mathrm{~S}$ ribosomal subunit; localized to the cytosol only; may result from a pseudogene. & \\
\hline P39019 & RPS19 & $40 \mathrm{~S}$ ribosomal protein S19 & $\begin{array}{l}\text { Component of the } 40 \mathrm{~S} \text { ribosomal subunit; required for pre-rRNA processing and maturation of } 40 \mathrm{~S} \\
\text { ribosomal subunits; involved in translation initiation; binds RNA; protein kinases and fibroblast growth } \\
\text { factor (FGF); involved in NOTCH signaling. }\end{array}$ & $\begin{array}{l}\text { Diamond-Blackfan anemia, } \\
\text { type 1; highly expressed in } \\
\text { colon carcinoma. }\end{array}$ \\
\hline P62854 & RPS26 & $40 \mathrm{~S}$ ribosomal protein S26 & $\begin{array}{l}\text { Component of the } 40 \mathrm{~S} \text { ribosomal subunit; involved in translation initiation; binds RNA and mRNA; binds } \\
\text { cadherin; negatively regulates pre-mRNA splicing; }\end{array}$ & $\begin{array}{l}\text { Diamond-Blackfan anemia, } \\
\text { type } 10\end{array}$ \\
\hline P56182 & RRP1 & $\begin{array}{l}\text { Ribosomal RNA processing } \\
\text { protein } 1 \text { homolog A }\end{array}$ & RNA binding protein critical to the generation of $28 \mathrm{~S}$ rRNA. & \\
\hline Q9Y3B9 & RRP15 & RRP15-like protein & Involved in rRNA processing. & \\
\hline Q96EU6 & $R R P 36$ & $\begin{array}{l}\text { Ribosomal RNA processing } \\
\text { protein } 36 \text { homolog }\end{array}$ & $\begin{array}{l}\text { Involved in the early processing steps of the pre-rRNA in maturation pathway leading to the } 18 \mathrm{~S} \text { rRNA; } \\
\text { involved in the cleavage to liberate } 18 \mathrm{~S} \text { rRNA. }\end{array}$ & \\
\hline Q9UHA3 & RSL24D1 & $\begin{array}{l}\text { Probable ribosome biogenesis } \\
\text { protein RLP24 }\end{array}$ & $\begin{array}{l}\text { Involved in the biogenesis of the } 60 \mathrm{~S} \text { ribosomal subunit; insures NOG1 docking to } 60 \mathrm{~S} \text { ribosomal subunit; } \\
\text { structural component of the ribosome; involved in translation. }\end{array}$ & \\
\hline Q9Y265 & RUVBL1 & RuvB-like 1 & $\begin{array}{l}\text { ATP-dependent DNA helicase; component of the NuA4 histone acetyltransferase complex; binds to the } \\
\text { TF-IID transcription complex; involved in H2A and H4 acetylation and RNA pol II transcriptional } \\
\text { activation; involved in C/D snoRNP assembly; has a role in DNA repair; required for MYC oncogenesis. }\end{array}$ & \\
\hline Q9Y230 & RUVBL2 & RuvB-like 2 & $\begin{array}{l}\text { ATP-dependent DNA helicase; component of the NuA4 histone acetyltransferase complex; binds to the } \\
\text { TF-IID transcription complex; involved in H2A and H4 acetylation and RNA pol II transcriptional } \\
\text { activation; involved in C/D snoRNP assembly; has a role in DNA repair; binds } \beta \text {-catenin; required for } \\
\text { MYC oncogenesis; suppresses expression of ATF2 and endoplasmic reticulum stress response genes. }\end{array}$ & \\
\hline P28370 & SMARCA1 & $\begin{array}{l}\text { Probable global transcription } \\
\text { activator SNF2L1 (1) }\end{array}$ & Chromatin remodeling DNA-binding protein; positively regulates RNA pol II transcription. & \\
\hline
\end{tabular}


Table 2. Cont

\begin{tabular}{|c|c|c|c|c|}
\hline Acc \# & Gene Name & Description & Function & Involvement in Disease \\
\hline P51532 & SMARCA4 & Transcription activator BRG1 & $\begin{array}{l}\text { Chromatin remodeling DNA-binding protein; associates with p53; associates with long non-coding RNAs; } \\
\text { acts as a transcriptional coactivator or corepressor; positive regulation of RNA pol II pre-miRNA } \\
\text { transcription. }\end{array}$ & $\begin{array}{l}\text { Rhab doid tumors and } \\
\text { Coffin-Siris syndrome } 4 \text { (CSS4) }\end{array}$ \\
\hline O60264 & SMARCA5 & $\begin{array}{l}\text { SWI/SNF-related } \\
\text { matrix-associated } \\
\text { actin-dependent regulator of } \\
\text { chromatin subfamily A member } \\
5\end{array}$ & $\begin{array}{l}\text { Chromatin remodeling DNA-binding protein; represses RNA pol-dependent transcription of rDNA; } \\
\text { regulates chromatin silencing by recruiting DNA methyltransferases to stretches of rDNA. }\end{array}$ & \\
\hline Q92922 & SMARCC1 & $\begin{array}{l}\text { SWI/SNF complex subunit } \\
\text { SMARCC1 }\end{array}$ & $\begin{array}{l}\text { Chromatin remodeling DNA-binding protein; component of the SWI/SNF chromatin remodeling complex; } \\
\text { acts as a positive regulator of RNA pol II-dependent transcription; may repress certain genes. }\end{array}$ & \\
\hline Q8TAQ2 & SMARCC2 & $\begin{array}{l}\text { SWI/SNF complex subunit } \\
\text { SMARCC2 }\end{array}$ & $\begin{array}{l}\text { Chromatin remodeling DNA-binding protein; component of the SWI/SNF chromatin remodeling complex; } \\
\text { acts as a positive regulator of RNA pol II-dependent transcription; may repress certain genes. }\end{array}$ & \\
\hline P09661 & SNRPA1 & $\begin{array}{l}\mathrm{U} 2 \text { small nuclear } \\
\text { ribonucleoprotein } \mathrm{A}^{\prime}\end{array}$ & $\begin{array}{l}\text { Part of the spliceosome complex involved in pre-mRNA splicing; part of the U2 snRNP; associates with U2 } \\
\text { snRNA. }\end{array}$ & \\
\hline P62316 & SNRPD2 & $\begin{array}{l}\text { Small nuclear ribonucleoprotein } \\
\text { Sm D2 }\end{array}$ & $\begin{array}{l}\text { Core component of the SMN-Sm complex that mediates snRNP assembly, which occurs in the cytoplasm; } \\
\text { facilitates nuclear import of snRNPs; is a component of the U1, U2, U4, and U5 snRNPs; binds RNA; } \\
\text { required for pre-mRNA splicing; auto-antibodies found in lupus. }\end{array}$ & \\
\hline P62318 & SNRPD3 & $\begin{array}{l}\text { Small nuclear ribonucleoprotein } \\
\qquad \text { Sm D3 }\end{array}$ & $\begin{array}{l}\text { Core component of the SMN-Sm complex that mediates snRNP assembly, which occurs in the cytoplasm; } \\
\text { facilitates nuclear import of snRNPs; is a component of the U1, U2, U4, and U5 snRNPs; binds RNA; } \\
\text { required for pre-mRNA splicing; binds to the downstream cleavage product (DCP) of histone pre-mRNA } \\
\text { in a U7 snRNP dependent manner; auto-antibodies found in lupus. }\end{array}$ & \\
\hline P18583 & $S O N$ & Protein SON & $\begin{array}{l}\text { mRNA splicing cofactor; enhances splicing of mRNAs with weak splice sites, including many cell cycle } \\
\text { and DNA repair genes, through the interaction with SRSF2 and RNA pol II. }\end{array}$ & ZTTK syndrome \\
\hline $\mathrm{O} 15042$ & $S R 140$ & $\begin{array}{l}\text { U2 snRNP-associated SURP } \\
\text { motif-containing protein }\end{array}$ & RNA binding; involved in mRNA splicing. & \\
\hline Q8IYB3 & SRRM1 & $\begin{array}{l}\text { Serine/arginine repetitive matrix } \\
\text { protein } 1\end{array}$ & $\begin{array}{l}\text { Part of pre- and post-splicing multiprotein mRNP complexes; links sequence-specific splicing factors with } \\
\text { snRNP factors of the splicesome; involved in mRNA nuclear export. }\end{array}$ & \\
\hline Q01130 & $S R S F 2$ & $\begin{array}{l}\text { Serine/arginine-rich splicing } \\
\text { factor } 2\end{array}$ & $\begin{array}{l}\text { Required for pre-mRNA splicing; facilitates U1 and U2 snRNP association with pre-mRNA; links } 5^{\prime} \text { and } 3^{\prime} \\
\text { splice site components U1 snRNP and U2AF, respectively; regulates alternative splicing; facilitates mRNA } \\
\text { export from the nucleus; acts as a transcriptional corepressor. }\end{array}$ & \\
\hline Q13247 & SRSF6 & $\begin{array}{l}\text { Serine/arginine-rich splicing } \\
\text { factor } 6\end{array}$ & $\begin{array}{l}\text { Plays a role in constitutive splicing and can modulate the selection of alternative splice sites; involved in } \\
\text { mRNA export from the nucleus. }\end{array}$ & \\
\hline Q08945 & SSRP1 & FACT complex subunit SSRP1 & $\begin{array}{l}\text { DNA-binding component of the FACT complex; involved in RNA pol II mRNA elongation, DNA } \\
\text { replication, and DNA repair; may influence p53 stability; auto-antibodies found in lupus. }\end{array}$ & \\
\hline P53999 & SUB1 & $\begin{array}{l}\text { Activated RNA polymerase II } \\
\text { transcriptional coactivator p15 }\end{array}$ & $\begin{array}{l}\text { RNA and DNA binding protein that acts as a coactivator of TAF complex-mediated RNA polymerase II } \\
\text { transcription. }\end{array}$ & \\
\hline O75683 & SURF6 & Surfeit locus protein 6 & RNA and DNA binding protein likely involved in ribosome biogenesis and assembly. & \\
\hline
\end{tabular}


Table 2. Cont

\begin{tabular}{|c|c|c|c|c|}
\hline Acc \# & Gene Name & Description & Function & Involvement in Disease \\
\hline O60506 & SYNCRIP & $\begin{array}{l}\text { Heterogeneous nuclear } \\
\text { ribonucleoprotein } Q\end{array}$ & $\begin{array}{l}\text { An hnRNP implicated mRNA processing; three isoforms function diversely; involved in splicing and } \\
\text { mRNA turnover; inhibits translation; promotes MYC mRNA stability; part of APOB editsome; may } \\
\text { facilitate cytoplasmic vesicle transport of RNAs. }\end{array}$ & \\
\hline Q92804 & TAF15 & $\begin{array}{c}\text { TATA-binding } \\
\text { protein-associated factor } 2 \mathrm{~N}\end{array}$ & An RNA and ssDNA binding protein with RNA pol II-mediated transcription promoting characteristics. & $\begin{array}{l}\text { Extra skeletal myxoid } \\
\text { chondrosarcoma }\end{array}$ \\
\hline Q8NI27 & THOC2 & THO complex subunit 2 & $\begin{array}{l}\text { A component of the THO complex that is a sub-component of the TREX complex; associates with spliced } \\
\text { and polyA mRNA to export then from the nucleus; required for the release of mRNA from nuclear } \\
\text { speckles. }\end{array}$ & $\begin{array}{l}\text { Mental retardation, X-linked } 12 \\
\text { (MRX12) }\end{array}$ \\
\hline P62995 & TRA2B & $\begin{array}{l}\text { Transformer-2 protein homolog } \\
\text { beta }\end{array}$ & $\begin{array}{l}\text { Sequence-specific RNA-binding protein that participates in the control of pre-mRNA splicing; can promote } \\
\text { or inhibit exon inclusion. }\end{array}$ & \\
\hline Q01081 & $U 2 A F 1$ & $\begin{array}{l}\text { Splicing factor U2AF } 35 \mathrm{kDa} \\
\text { subunit }\end{array}$ & $\begin{array}{l}\text { Constitutive and enhancer-dependent splicing by mediating protein-protein interactions and } \\
\text { protein-RNA interactions required for accurate } 3^{\prime} \text {-splice site selection; facilitates mRNA nuclear export. }\end{array}$ & $\begin{array}{l}\text { Myelodysplastic syndromes } \\
\text { (MDS) }\end{array}$ \\
\hline P26368 & $U 2 A F 2$ & $\begin{array}{l}\text { Splicing factor U2AF } 65 \mathrm{kDa} \\
\text { subunit }\end{array}$ & $\begin{array}{l}\text { Has a role in splicing of and } 3^{\prime} \text { processing of pre-mRNA; required for mRNA export; may link the } \\
\text { processes of transcription termination, polyadenylation and export. }\end{array}$ & \\
\hline Q9NQZ2 & UТРЗ & $\begin{array}{l}\text { Something about silencing } \\
\text { protein } 10\end{array}$ & Role in the structure of silenced chromatin; has a role in $40 \mathrm{~S}$ subunit rRNA processing. & \\
\hline Q15061 & WDR43 & $\begin{array}{l}\text { WD repeat-containing protein } \\
43\end{array}$ & $\begin{array}{l}\text { Ribosome biogenesis factor; required for RNA pol I-mediated transcription; involved in pre-18S rRNA } \\
\text { processing. }\end{array}$ & \\
\hline P67809 & YBX1 & $\begin{array}{l}\text { Nuclease-sensitive } \\
\text { element-binding protein } 1\end{array}$ & $\begin{array}{l}\text { pre-mRNA alternative splicing regulation; stabilizes cytoplasmic mRNAs; promotes the interaction of } \\
\text { mRNA with translation initiation factors; acts a transcription factor influencing the expression of } \\
\text { numerous genes through RNA pol II-specific means; possesses endonuclease activity; promotes MYC } \\
\text { mRNA stability. }\end{array}$ & \\
\hline
\end{tabular}




\section{RNA Editing/Splicing and Its Potential Role in Ribosome Biogenesis}

RNA editing and alternative splicing of RNA are fundamental cellular processes that enhance the possibility of gene expression and increase protein diversity. Any impairment of these mechanisms is associated with the failure of normal cellular homeostasis resulting in disease $[2,144]$. The importance of RNA editing and/or splicing in coding RNAs (mRNAs) has become increasingly evident, but it may very well be the affect these processes have on non-coding RNAs (miRNAs, long non-coding RNAs, etc.) that is most critical to an organisms development and maintenance; and whose aberrant regulation may be responsible for diverse pathogenic conditions.

In coding mRNAs, alternative splicing can alter the amino acid sequence of the resulting protein, which can affect its function/activity or localization. It can also influence the translation efficiency and stability of the encoding mRNA and, thus, regulate protein expression post-transcriptionally (but pre-translationally) when it occurs in the $5^{\prime}$ - and $3^{\prime}$-untranslated regions of the mRNA. Numerous interacting components of the spliceosome complex and associated heterogeneous nuclear RNPs (hnRNPs) are involved along with cis-acting elements in the primary transcript. This mechanism is finely regulated at developmental stages in different tissues, and an alteration in regulation of alternative splicing is now linked with several human diseases, including leukemia and pre-leukemic states such as MDS $[2,145]$. Splicing factor 3B subunit 1 (SF3B1), U2 small nuclear RNA auxiliary factor 1 (U2AF1), serine/arginine-rich splicing factor (SRSF2), and zinc finger CCCH-type, RNA binding motif and serine/arginine-rich 2 (ZRSR2) are splicing factors that carry recurrent somatic mutations in MDS and are components of the E/A splicing complex that coordinates $3^{\prime}$ splice site recognition during the early phase of pre-mRNA processing [2,146-148]. With regards to ribosomal proteins and regulators of ribosome biogenesis, the presence of alternatively spliced forms and their influence is just beginning to gain ground. Recent studies by Mei et al. and Rendleman et al. have demonstrated the presence of alternately spliced forms of p70 S6K1 and aminoacyl-tRNA synthetases, respectively. While the p70 S6K1 variant was found to be highly expressed in non-small cell lung cancer (NSCLC), the splice variants of aminoacyl-tRNA synthetases were observed under stress conditions and likely represent part of the cellular stress response [149,150]. Likewise, Mrvovà et al. reported the identification of diverse alternatively spliced forms of eIF4E family members in acute lymphoblastic leukemia cell lines [151]. These alternatively spliced mRNAs were shown to either contain different polyadenylation sites, affecting the stability of the mRNA, or encode diverse C-termini, potentially altering the function of the protein. Additionally, alternatively spliced transcripts of the DNA polymerase delta-interacting protein 3 (POLDIP3), a direct target of p70 S6K1, have been reported [152]. Most recently, the presence of alternatively spliced ribosomal proteins has been documented. Data across species agree that alternate forms of the ribosomal proteins due to alternative splicing are extremely rare; most alternative forms such as RPL10 versus RPL10-like (RPL10L) are instead due to tissue specific expression of one gene over another. Gupta and Warner reported that in the ENCODE database, of the 376 introns from RPs catalogued, only one was alternatively spliced [153]. Interestingly, this does not indicate that RP expression is not regulated by alternative splicing. Diverse groups have found that many RP mRNAs are alternatively spliced leading mRNAs termed "pseudogenes" that are targeted for non-sense mediated degradation. Plocik and Guthrie demonstrated in Drosophila, with RPS9, that the alternative spliced RPS9 mRNAs serve to regulate the accumulation and expression of RPS9, providing a clear example of how alternative splicing may influence RP expression without producing alternative protein isoforms [154]. Carlston et al. described in a recent case report, a 2-year-old boy with Diamond-Blackfan anemia resulting from a maternally inherited mutation that led to alternative splicing of RPL11 mRNA. The authors state that the resulting protein was susceptible to missense-mediated decay, accounting for the haploinsufficiency of RPL11 in this individual [155]. Two additional studies have suggested a role for the hnRNP complexes in RP alternative splicing. A study by Aviner et al. identified the hnRNP C, a protein-RNA complex involved in splicing, as being critical to the translation of mRNAs encoding ribosomal proteins and translation factors [156]. More importantly, Liu et al. recently reported that hnRNP K directly enhances the alternative splicing 
of mitochondrial RPL33 (MRPL33) producing MRPL33-L, which has increased tumor promoting potential and is associated with colorectal cancer [157]. Findings of frequent mutations in genes involved in RNA splicing in myelodysplasia and other diseases have resulted in the grouping of several pathologies as "spliceopathies" [158]. Furthermore, the activity of many splicing factors is regulated by phosphorylation through kinases such as AKT, CLKs, NEK2, PRP4, and TOP1. Alternative splicing may be a point of departure for the discovery of novel diagnostic and prognostic biomarkers as well as new therapeutic strategies to disease (for more detail, see [2]).

Other than nucleotide modifications to the RNA or the direct alteration and regulation of the splicing complex components, alternate splicing also involves sequence specific cis-elements that can be modified by a process known as "RNA editing"; thereby changing the splice acceptor/donor sites to generate alternatively spliced mRNAs. "RNA editing" is an important post-transcriptional mechanism, occurring in a wide range of organisms, which alters the primary RNA sequence through the insertion/deletion or modification of specific nucleotides. By far the most important mechanism is through the deamination of cytosine or adenosine residues. Three families of enzymes are primarily responsible for this type modification: The apolipoprotein B mRNA editing enzyme, catalytic polypeptide-like (APOBEC) family of cytidine deaminase members, APOBEC1, APOBEC2, and APOBEC4; the adenosine deaminase acting on tRNA family (ADAT1, ADAT2, and ADAT3), and the adenosine deaminase acting on double-strand RNA (dsRNA) family (ADAR1, ADAR2, and ADAR3).

The APOBEC family (APOBEC1, APOBEC2, APOBEC3A-H, APOBEC4, and activation-induced adenosine deaminase (AID)) is thought to be an innate immune-related gene cluster. Members of this family deaminate cytidine $(\mathrm{C})$ or deoxycytidine $(\mathrm{dC})$ to form uracil $(\mathrm{U})$ or deoxyuracil (dU), respectively, in their targets, which vary greatly depending on the enzyme, tissue, and cellular localization [159]. The APOBEC 3 members and AID target ssDNA. In contrast, APOBEC1, APOBEC2, and APOBEC4 are the only members of the cytidine deaminases to specifically target RNA. These enzymes work as homodimers or homotetramers, and their expression is tissue/organ specific: Small intestine (APOBEC1), heart and skeletal muscle (APOBEC2), or testes (APOBEC4) [159]. Although cytidine deaminases account for a minority of RNA editing events in the cell, mutations in several of these enzymes are associated with disease (Figure 5).

Adenosine deaminations to inosine (A-to-I editing), in contrast, account for the majority of RNA editing events in the cell. Inosine is interpreted by the cellular machinery as guanine, thus A-to-I RNA editing within mRNAs and ncRNAs (long ncRNA and miRNAs) increase the human RNA/protein landscape [160]. In pre-mRNAs, A-to-I editing can generate or destroy splice sites and alter codons, thus increasing proteome diversity. In addition, the modification of RNA transcripts at the $5^{\prime}$ and $3^{\prime}$ untranslated regions (UTRs) can alter translation and stability of the mRNA, respectively. Moreover, modifications of ncRNAs (miRNAs, long ncRNAs, snoRNAs, and scaRNAs) can alter their target specificity or function $[160,161]$. Recently, it has been reported that the A-to-I RNA editing frequency is massively increased from mouse to human [162]. In humans, most A-to-I RNA editing events $(\geq 90 \%)$ occur within $A l u$ inverted repeats, located preferentially in gene-rich regions. The majority of identified adenosine to inosine modifications in the cell have been linked to one of two families of adenosine deaminases: The ADAR family or the ADAT family. Ironically, both families consist of three members, with two members being active enzymes (ADAT-1 and -2; ADAR-1 and -2) and the third (ADAT3; ADAR3) demonstrated to be catalytically inactive.

The adenosine deaminase acting on tRNA (ADAT) family consists of ADAT1, ADAT2, and ADAT3 and is responsible for deamination within tRNAs, which represents a minor fraction of the A-to-I editing in the cell. The targets of ADAT1 and ADAT2 known to date are rather specific. ADAT1 specifically deaminates adenosine 37 in the anti-codon loop of tRNA-Ala. On the other hand, ADAT2 specifically deaminates adenosine 34 in a variety of tRNAs. To date, 7-8 different tRNAs containing I34 have been identified. ADAT3, which is highly homologous to ADAT2 over 120 amino acids of the deaminase motif, is believed to be catalytically inactive [163]. Editing of A-34-I is associated with the 
heterodimetric ADAT (hetADAT), which is composed of ADAT2/ADAT3; thus, ADAT3 regulates the activity of ADAT2. Cellular localization of the ADAT enzymes is strictly cytoplasmic $[163,164]$. The consequences of the modifications catalyzed by these enzymes have not been fully elucidated, but likely influence translation elongation under stress conditions, the possible use of altered initiation codons, premature termination of translation, or possibly allow codon slipping of the elongating ribosome to favor a shift in the reading frame [164-166]. The regulation of theses protein has not been thoroughly investigated (Figure 5).
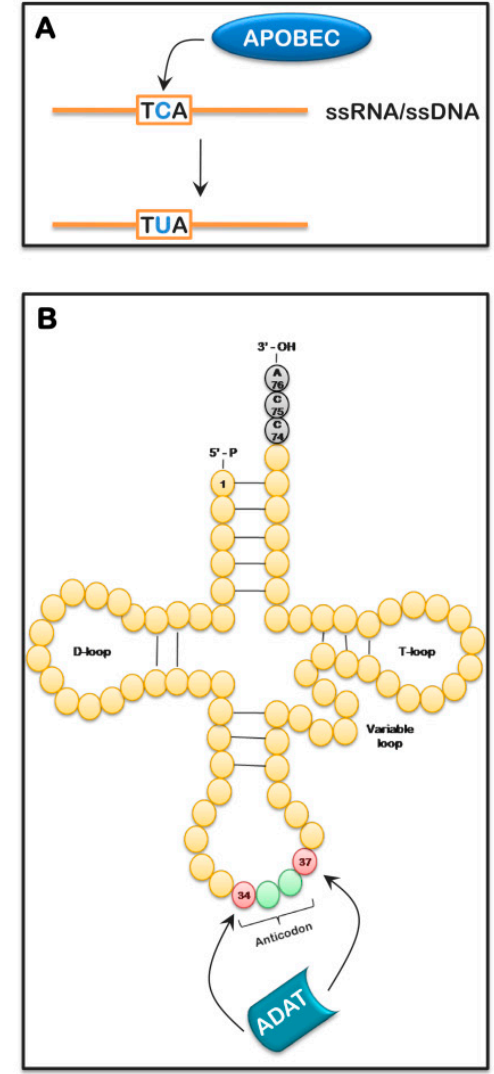

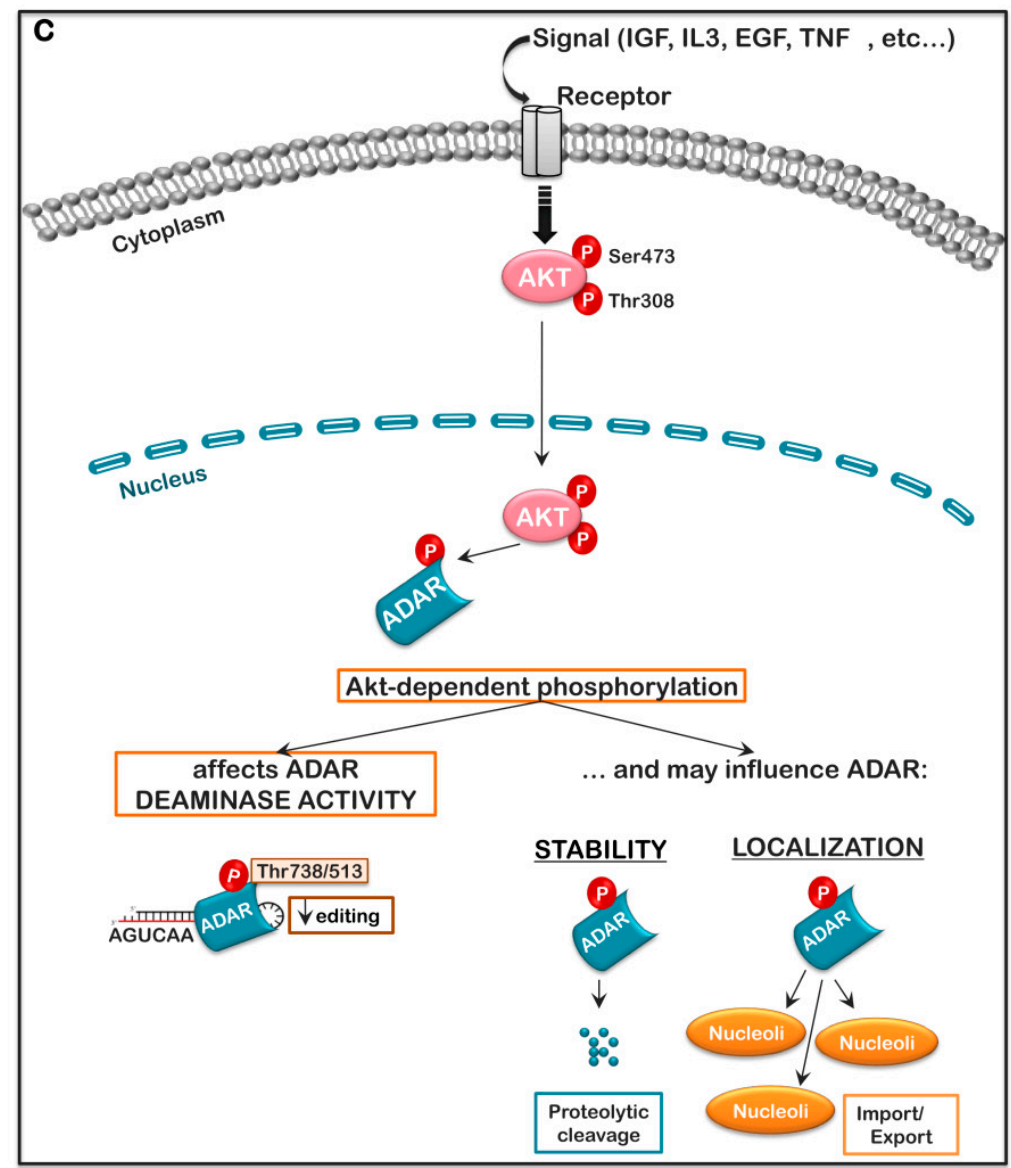

Figure 5. Adenosine deamination can modify diverse RNA species affecting ribosome biogenesis and translation. The APOBEC, ADAT, and ADAR families are capable of deaminating key adenosine (A) residues to inosine (I) in RNA resulting in alternative splicing, amino acid composition of proteins, siRNA target sequence recognition, snRNP activity, and RNA transport. In addition, each of these alterations can have pleotropic effects. (A) The APOBEC enzymes deaminate cytidine residues in ssRNA and ssDNA. (B) The ADAT family modifies adenosine residues in tRNA potentially altering translation initiation, elongation, or termination. (C) The ADAR family modifies adenosine residues in dsRNAs. Recently, AKT has been shown to phosphorylate and regulate ADAR editase activity.

In higher mammals, the most common type of RNA editing is mediated by the ADAR family within dsRNA regions of coding and non-coding primary transcripts. Like the ADATs, there are three highly conserved members of the ADAR family: ADAR1 (or DSRAD), ADAR2, and ADAR3. Both ADAR1 and ADAR2 are ubiquitously expressed (ADAR2 being most abundant in the brain), while ADAR3 expression is restricted to neural tissue, namely the brain [167]. Each of these enzymes contain dsRNA-binding domains (dsRBDs), three in ADAR1, and two in both ADAR2 and ADAR3, which allow them to bind/localize with their substrates, and a catalytic deaminase domain at the C-terminus. While ADAR1 and ADAR2 are active enzymes, ADAR3 is catalytically inactive [168]. Since these enzymes work as homo- or heterodimers, the presence of ADAR3 may serve to regulate 
ADAR1- and ADAR2-dependent editing or sequester substrates of ADAR1 and ADAR2. Unlike the ADAT deaminases, the localization of the ADARs is for the most part restricted to the nucleus, nucleoli, and nucleoplasm with the exception of ADAR1 [167]. Two main isoforms of ADAR1 are generated by alternate transcriptional initiation from exons $1 \mathrm{~A}, 1 \mathrm{~B}$, or $1 \mathrm{C}$. As exons $1 \mathrm{~B}$ and $1 \mathrm{C}$ do not contain a start codon, translation of mRNAs beginning with these alternate exons initiates in exon 2, producing a protein of $103 \mathrm{kDa}$, known as ADAR1p110, which is mainly nuclear. In contrast, transcriptional initiation at exon $1 \mathrm{~A}$ is strictly interferon-inducible, and, due to the presence of a translational start codon in exon 1A, the transcript produces a protein 295 amino acids longer (136 kDa), known as ADAR1p150, which can shuttle between the cytoplasm and nucleus $[169,170]$. On the other hand, two main forms of ADAR2 have been described, a result of alternative splicing, which are referred to as ADAR2 long ( $81 \mathrm{kDa}$ ) or the more enzymatically active ADAR2 short (ADAR2a; $\triangle \mathrm{aa} 466-605$; $77 \mathrm{kDa})$ [171].

Over the years, diverse targets of ADAR-mediated editing have been reported. Due to limited availability of high-throughput technology, many of the first RNA substrates identified were those in mRNAs that produce an identifiable change in the cDNA (as compared to the corresponding genomic sequences) and, in some cases, the amino acid sequence of the encoded protein. Advancements in technology and next generation sequencing have allowed for more large-scale analyses and identification of RNA editing sites within introns, Alu repeats, and non-coding RNAs, including many that play a role in ribosome biogenesis [168]. The function of many of these A-to-I modifications has not been examined. Of particular interest is the fact that while ADAR1p110 and ADAR2 are believed to localize to the nucleolus through interactions with the structural transcribed spacer regions of the rRNA, to date, in mammals, no known sites of A-to-I editing in rRNA have been reported [168,172]. The reason is likely two-fold: 1) rRNAs possess a very low adenosine content, thus limiting the available substrates for modification and 2) many current whole transcriptome studies use an rRNA depletion step to reduce background noise and non-specificity. In contrast, Eifler et al. reported that ADAR2 was able to modify the 25S rRNA as well as the splicing complex RNAs U1 snRNA and U2 snRNA in yeast [161]. Whether the ADARs directly modify rRNAs or not, their presence in the nucleolus and nucleoplasm likely has significant consequences on ribosome biogenesis through recruitment and/or modification of secondary proteins and RNAs necessary for rRNA synthesis and maturation.

As stated, little information exists on the regulation of these enzymes beyond their expression and the fact that multiple splice variants are reported. Multiple studies have identified post-translational modifications on numerous residues in ADAR1 and ADAR2 in vivo (https:/www.phosphosite.org/ proteinAction.action?id=10051\&showAllSites=true and https://www.phosphosite.org/proteinAction. action?id=5859\&showAllSites $=$ true), and several recent publications have demonstrated the importance of phosphorylation to ADAR activity. Sakurai et al. demonstrated that stress-induced phosphorylation of ADAR1p110 in the disorganized region between dsRNA-binding domain III and the editase domain by the MKK6-p38-MSK MAPK pathway resulted in the association of Exportin-5 with ADAR1p110 and the export of ADAR1p110 from the nucleus to the cytosol, where it blocks Staufen 1-mediated decay, promoting apoptosis [173]. Likewise, Shelton et al. demonstrated that ADAR2 was phosphorylated at two sites between the dsRNA-binding domains, Ser211 and Ser216, by PKC $\xi$. Phosphorylation at these sites was demonstrated to regulate ADAR2 RNA editing activity toward miR-200, and the subsequent secretion of this miRNA [174]. Bavelloni et al. recently reported that both ADAR1p110 and ADAR2 are substrates for the AKT kinase family. Inhibition AKT with either the allosteric inhibitor, MK2206, or the ATP binding site inhibitor, AZD5363, resulted in enhanced ADAR1- and ADAR2-dependent editing of known substrates in treated U-87MG cells. AKT1 was found to primarily phosphorylate S738 in ADAR1p110 and S553 in ADAR2, within the catalytic domain. Expression of either phosphomimic mutant, ADAR1p110-S738D or ADAR2-S553D, resulted in reduced ADAR1- and ADAR2-dependent editing [74]. A full analysis of the effects of this regulation on global ADAR-dependent editing is still needed. Thus, not only can downstream signaling of the PI3K-AKT pathway influence ribosome 
biogenesis through mTOR and p70 S6K, it potentially has a significant role in regulating global regulators of RNA metabolism/processing (Figure 5).

Additionally, ADAR1 has a strict relation with PKR in stress granules. Stress granules are cytoplasmic aggregates of stalled $40 \mathrm{~S}$ ribosomal subunit-containing translation initiation complexes linked to eIF2 $\alpha$ Ser51 phosphorylation and are a hallmark of negative-strand RNA virus infection. ADAR1p150 was shown to co-localize with PKR in stress granules in the cytoplasm and inhibit PKR activity. George et al. demonstrated that in cells lacking ADAR1 (ADAR1-/-), treatment with IFN lead to increased eIF2 $\alpha$ Ser51 phosphorylation and PKR-dependent stress granule formation [175]. Interestingly, similar to other components of ribosome biogenesis, it has been shown that ADAR1 expression and editase activity are required for normal erythropoiesis, as cells deficient in ADAR1 undergo enhanced apoptosis. [176] In the nucleus, PKR is known to directly bind ADAR1p110, but the significance of this interaction has not yet been elucidated [39]. Seeing that PKR and AKT often play a tug-of-war, it is possible that nuclear PKR activity is also regulated by ADAR1 or that ADAR1p110 may represent a substrate for active nuclear PKR. Given the biological relevance of RNA editing in mammals, it has been postulated that its deregulation could be linked to a variety of human disorders.

\section{Ribosome Biogenesis and Disease (Ribosomopathies)}

Several pathologies have their etiology founded in altered ribosome biogenesis and result from both acquired as well as hereditary mutations. Interestingly, while hereditary germline alterations are present in every nucleated cell of the organism, the associated pathologies strictly affect tissues and cells that have a high demand for protein synthesis or proliferation/cell turnover. Almost all these pathologies exhibit a large hematological component and patients with ribosomopathies almost always present with hematopoietic abnormalities, due to bone marrow failure. Erythroid progenitors are particularly sensitive due to the high demand for globin synthesis and rapid cell turnover. Thus, it is no wonder a number of the ribosomopathies are also termed bone marrow failure disorders (BMFDs). Patients with ribosomopathies/BMFDs often have clinical signs of a chronic, overactive innate immune/inflammatory response with elevated levels of circulating inflammatory mediators, such as TNF $\alpha$, IL- $1 \alpha$, and IFN $\gamma$, which suppress the growth of progenitors and stimulate apoptosis in the bone marrow and other hypersensitive tissues $[2,177,178]$. Interestingly, while ribosomopathies appear to have a pro-apoptotic effect on the affected tissues, individuals who suffer from these pathologies have an increased incidence of developing cancers. One hypothesis is linked to the association between chronic inflammation and cancer. Ribosomopathies may represent the classic case of a chronic inflammatory state affecting tissues with an elevated necessity for protein synthesis and cell turnover. Prolonged ribosomal stress, like chronic inflammation, may place a selective pressure on the affected cells. Progenitor cells that are able to escape this selective pressure and proliferate are cells that have, over time, acquired random gain of function mutations, leaving them with characteristics of cancer stem cells $[2,56,179]$.

\subsection{Acquired Ribosomopathies: 5q-Syndrome}

As far as acquired ribosomopathies go, only one pathology currently stands-out, $5 q$ - myelodysplastic syndrome (MDS; 5q- syndrome). Myelodysplastic syndromes are a heterogeneous group of hematological malignancies that result in cytopenias in one or more of the hematologic lineages, with or without cytogenetic abnormalities. De novo MDS typically occurs in later life ( $>60$ years of age) and is, thus, considered an age-related disorder. In contrast, MDS can also arise from the progression of other hematological malignancies, including other BMFDs. Moreover, therapy-related MDS (tMDS) is known to occur in individuals previously treated with chemotherapeutic agents for diverse types of cancer $[2,180]$.

MDS is categorized by the International Prognostic Scoring System (IPSS) as low, intermediate-1, intermediate-2, and high, based on the risk of the disease progressing to acute leukemia. In low-risk disease, there is a propensity for hematologic stem cells and progenitors to undergo apoptosis with few 
blasts observed in the peripheral blood. This is gradually replaced during disease progression from low- to high-risk, where there is hypercellularity of the bone marrow and the appearance of blasts in the periphery $[2,180,181]$.

Diverse groups have demonstrated a role for stress/inflammatory signaling during progression of MDS to AML $[56,134,182]$. More recently, significant alterations in DNA methylation, chromatin modification, transcriptional regulation, DNA repair, signal transduction, sister chromatid cohesion and RNA splicing, and ribosome biogenesis associated genes have been observed. Certain mutations are specific to particular subtypes of myelodysplasia $[2,148,183,184]$. In the case of 5q- syndrome, a deletion of the long arm of chromosome 5, which encodes rps14, results in a haploinsufficiency of RPS14 [48]. Loss of RPS14 results in defective ribosome biogenesis and translation, the stimulation of p53 transcriptional activation, cell cycle arrest, and enhanced apoptosis especially in erythroid progenitors, resulting in anemia [185]. To date, 5q- syndrome is the only myelodysplastic disease to be labeled a ribosomopathy. This is not to say that other types of MDS or other acquired BMFDs might not, in fact, be ribosomopathies, but currently, data does not exist to conclusively suggest that these other acquired BMFDs result from an altered ribosome component.

\subsection{Acquired Ribosomopathies (Potential): T-Cell Acute Lympoblastic Leukemia}

A number of cancers that are not currently classified as ribosomopathies have been found to contain mutations in ribosomal proteins, which result in defective or altered ribosome synthesis; these include glioma, colorectal cancers, chronic lymphocytic leukemia (CLL), and T-cell acute lymphoblastic leukemia (T-ALL) [186]. In the case of T-ALL, mutations in RPL5, RPL10, and RPL11 have been identified, with mutations in RPL5 or RPL10 being found in about 10\% of pediatric T-ALL patients [187]. One of the original driver mutations observed in T-ALL was that of the NOTCH1 receptor. Activating NOTCH1 mutations are present in more than $50 \%$ of T-ALL cases. Pioneering work by Palomero et al. identified the loss of PTEN function and subsequent PI3K-AKT-mTOR pathway activation as critical to mutant NOTCH1 effects [188]. Suppression of PTEN function has been demonstrated to occur by both genetic and non-genetic mechanisms. Anywhere from $11 \%-27 \%$ of pediatric T-ALL patients show deletions, insertion, or point mutations in the PTEN gene, accounting for reduced activity [189]. Reduced PTEN activity has also been linked to alternate splicing of PTEN mRNA, phosphorylation of PTEN by casein kinase 2 (CK2), and miRNA targeted decay of the transcript [189]. In addition, aberrant NOTCH1 activity results in the activation of the downstream transcription factor target, hairy and enhancer of split-1 (HES1), which suppress PTEN expression $[188,189]$. Thus, aberrant NOTCH1 signaling and PTEN suppression are critical to T-ALL clonality and maintenance. What remains elusive though is, do these alterations favor mutations in the observed ribosomal proteins or do mutations in the observed ribosomal proteins favor the alterations of NOTCH1 and PTEN. A case could be made for either.

It is evident in most ribosomopathies that defective ribosome biogenesis presents a selective pressure on the cell that over time leads to the development of a population of cells that have acquired the potential to overcome this obstacle, giving these cells a selective advantage. Two recent publications could make the argument that this is at play in T-ALL. Chronic inflammation is known to play a role in diverse metabolic pathologies. Villegas et al. found that the pro-inflammatory enzymes, nitric oxide synthase (NOS) and lipoxygenase (LOX), stimulated NOTCH-PI3K/AKT oncogenesis and that inhibition of these pro-inflammatory enzymes was able to suppress NOTCH-PI3K/AKT signaling, resulting in leukemic cell death [190]. These data link NOTCH-PI3K/AKT signaling directly to inflammation. Interestingly, while oncogenic transformation can induce inflammation, one of the definitive side-effects of altered ribosome biogenesis observed in ribosomopathies is a pro-inflammatory phenotype. Even more interesting was the finding by Grzes et al. that primary T-ALL cells have an increased capacity for leucine uptake and transport [191]. As stated previously, the uptake of leucine can stimulate mTORC1 activity at the lysosome, and treatment of patients with certain hereditary ribosomopathies with L-leucine is able to alleviate the pro-apoptotic phenotype 
and resulting anemia. Interestingly, the authors found that PTEN deletion alone could not result in L-leucine uptake; NOTCH1 signaling was required. NOTCH1 signaling resulted in enhance expression of the sodium-independent solute carrier family 7, member 5 transport protein, which is involved in leucine uptake and transport [191]. Thus, one might argue that alterations in ribosome biogenesis may favor NOTCH1 mutations. Data from Sulima et al. might also support this scenario [192]. Their data has demonstrated that the most common RPL10 mutation observed in pediatric T-ALL, Arg98Ser, can induce a ribosome deficiency that results in a hypoproliferative state. Over time, these ribo-deficient cells acquire the ability to produce sufficient ribosomes and proliferate normally. While these cells can proliferate normally in the long-run, they produce defective ribosomes that result in both genomic and mRNA transcript instability, alterations often observed in advanced cancers, including T-ALL [192].

\subsection{Hereditary Ribosomopathies}

Hereditary ribosomopathies include: Diamond-Blackfan anemia (DBA), Shwachman-Diamond syndrome (SDS), Dyskeratosis congenital (DC), and Treacher-Collins syndrome (TCS). All involve the presence of an inherited mutation in one particular gene (SDS, TCS) or one member of a set of genes involved in a common cellular process (DBA, DC), which is ultimately responsible for the observed disease phenotype [178]. In ribosomopathies, where a mutation in more than one gene can cause the same disease, the pattern of inheritance and the penetrance of the disease phenotype may vary greatly. The involvement of particular tissues also depends at what point ribosome biogenesis and/translation is affected $[2,177]$.

\subsection{Diamond-Blackfan Anemia (DBA)}

Diamond-Blackfan Anemia (DBA) is a rare congenital bone marrow failure disorder often noted within the first year or two after birth. DBA is characterized by a profound anemia, with growth retardation, cranialfacial abnormalities, and defects in the heart and urinary system being observe in up to $50 \%$ of patients. Affected individuals have an increased incidence of developing MDS and AML, as well as some other forms of cancer $[2,178,193]$. DBA results from altered ribosomal RNA (rRNA) processing which, in turn, affects ribosome biogenesis of the 40S and 60S ribosomal subunits and alters mRNA processing/transport and translation; thus, having pleiotropic effects on cellular growth and survival $[2,193]$.

DBA, to date, has been associated with diverse mutations in the following ribosomal proteins: RPS7, RPS10, RPS17, RPS19, RPS24, RPS26, RPS27, RPS29, RPL5, RPL11, RPL26, RPL27, RPL35A, and the deletion of RPL15. Other novel mutations have been reported in RPL3L, RPL6, RPL7L1T, RPL8, RPL13, RPL14, RPL18A, and RPL31. Approximately 50\% of DBA patients contain mutations in RPS7, RPS10, RPS17, RPS19, RPS24, RPS26, RPS29, RPL5, RPL11, RPL26, RPL35A, or GATA. Of these, mutations in RPS19 alone account for $\sim 25 \%$ of these patients [2,194]. The other $50 \%$ of cases have, as of yet, no identified causative mutation, but are almost assuredly mutations associated with pre-rRNA processing and ribosome assembly.

There is some evidence that altered ribosome biogenesis may induce an inflammatory component. In patients bearing a RPS19 deficiency, the levels of GATA1 were found to be reduced in the erythroid progenitor population while p53 and TNF $\alpha$ expression were increased in the non-erythroid progenitors [26,193]. Inhibition of TNF $\alpha$ in a zebrafish model of RPS19-deficiency was able to rescue the observed anemia, suggesting TNF $\alpha$ expression has a significant role in the observed phenotype $[2,26]$. Similarly, stimulation of protein translation through the use of supplemental leucine has been reported to rescue the observed anemia [48].

\subsection{Shwachman-Diamond Syndrome (SDS)}

Shwachman-Diamond syndrome is an autosomal recessive disorder which initially manifests as an exocrine pancreatic dysfunction, but then results in bone marrow failure and skeletal abnormalities. Approximately $20 \%$ of SDS patients will progress to MDS while another $25 \%$ will develop AML [2,178]. 
In almost all cases $(\sim 90 \%)$, patients carry a mutation in the Shwachman-Blackfan-Diamond syndrome (SBDS) gene. The gene encoding SBDS is located on chromosome 7q11 and is immediately adjacent to its pseudogene, SBDSP, which is $97 \%$ identical to SBDS but contains deletions and nucleotide changes that prevent the expression of a functional protein. Interestingly, it is a recombination with this pseudogene that results in SBDS mutations in $75 \%$ of patients $[2,23]$. The SBDS gene encodes a 250 amino acid $(29 \mathrm{kDa})$ protein that contains no known structural domains. SBDS is expressed ubiquitously in tissues and is localized throughout the cell with a particular preference for the nucleolus where ribosome biogenesis occurs. Mouse knock-out models and the fact that a common early truncation mutation at nucleotide 183 (TA > CT) is observed only in individuals heterozygous for the defect, suggest that loss of SBDS is embryonic lethal [2,23].

As is the case for most bone marrow failure disorders, the number of CD34+ hematopoietic cells in the bone marrow is reduced, and these cells show a reduced proliferative and colony forming capacity when compared to normal CD34+ hematopoietic cells. In addition, elevated p53 expression and increased apoptosis are observed in the bone marrow of SDS patients [2,23].

SBDS associates with Nip7, a 60S ribosomal subunit assembly factor and eIF6 associated with the 605 ribosome. In the assembling 605 ribosomal subunit, eIF6 serves in the proper maturation of the subunit and to inhibit the premature assembly of the $40 \mathrm{~S}$ and $60 \mathrm{~S}$ subunits to form the $80 \mathrm{~S}$ ribosome. Mutational rescue data suggest that SBDS serves to disassociate eIF6 from the 60S subunit once it reaches the cytoplasm. This occurs by the SDBS-dependent recruitment of the cytoplasmic GTPase EFL1 to the eIF6-60S subunit complex. EFL1 promotes the dissociation of eIF6 from the 60S subunit, allowing for $80 \mathrm{~S}$ assembly $[2,23,24]$. Thus, during ribosome biogenesis, reduced expression of SBDS hampers the dissociation of eIF6. In addition to the 60S ribosomal subunit, SBDS has also been found in association with 28S rRNA and NPM1, so that, depending on the mutation in this gene, the observed phenotype may vary greatly [2,23]. SBDS has also been shown to associate with microtubules during mitosis. SBS patients often show increased incidence of mitotic abnormalities, with multi-polar spindles and centrosomal amplifications, but the general consensus is that disease-causing mutations in SBDS result in altered 60S ribosome biogenesis and an enhanced sensitivity to stress $[2,23]$.

\subsection{Dyskeratosis Congenita (DC)}

Dyskeratosis congenital (DC) is a highly rare multi-system progressive bone marrow failure disorder that can either present an autosomal dominant, autosomal recessive, or X-linked inheritance pattern base or the causative mutation. Its penetrance can vary widely extending from barely detectible to severe as in the case of Hoyeraal Hreidarson syndrome [2,178,195]. Dyskeratosis presents with a triad of symptoms that include reticulated skin hyperpigmentation, nail dystrophy, and mucosal leukoplakia and results in premature death resulting from bone marrow failure, respiratory dysfunction, or malignancy.

While dyskeratin (DKC1), which encodes for a protein involved both in the small nucleolar ribonucleoprotein (H/ACA snoRNP) and in the telomere complexes, and whose mutation is responsible for the X-linked form of DC, is by far the better studied; other proteins involved in the H/ACA snoRNP complex (NOP10 and NHP2), the telomerase ribonucleoprotein complex shelterin (TINF2); $T E R T$, the telomerase reverse transcriptase; TERC, which encodes the RNA component of TERT and whose mutation is responsible for the autosomal dominant form of DC; WRAP53, which delivers TERC to the telomerase as well as binds Cajal body RNAs (scaRNAs) and regulates p53 mRNA levels post-transcriptionally; RTEL1, which is involved in telomere elongation; and CTC1, a subunit of the CTC complex which terminates TERT activity and recruits DNA polymerase for complement strand synthesis, are also implicated $[2,178,195]$. All these proteins are involved in telomere maintenance, while several are also directly involved in small ribonuclear RNA processing, resulting in pseudouridylation of the snRNAs. Consensus seems to hold that the underlying cause of DC is the effect these mutations have on the telomeres and not the ribosomal effects per se. Although it should be stated that the transcription of the rDNA genes is closely related to genome stability, alterations in the telomerase 
complex would be expected to suppress rRNA transcription, while alterations in the H/ACA snoRNPs would be expected to influence rRNA processing [2,196,197]. As might be expected, tissues with the greatest proliferative/turnover rates are the most affected by DC.

\subsection{Treacher-Collins Syndrome (TCS)}

Treacher-Collins syndrome is an autosomal dominant disorder arising from an alteration in the tcof1 gene, which encodes the Treacle protein. A deletion of 5 bps in exon 24 accounts for about $20 \%$ of the cases. Individuals have midface hypoplasia, an underdeveloped outer ear structure, inner ear abnormalities, and developmental brain defects. Treacle co-localizes with UBF and RNA pol I to stimulate the transcription of the 47S pre-rRNA. Mouse models of TCS have demonstrated the upregulation of p53 and pronounced apoptosis of neural crest cells [177].

\section{Conclusions}

The cell has gone to great lengths to place multiple checks or ribosome biogenesis and translation initiation to avoid useless energy expenditure under unfavorable conditions (both intracellular and extracellular). Technological advances in next-generation sequencing and cryo-EM have begun to open the door on many aspects of ribosome biogenesis. Studies have demonstrated the order of RP incorporation into the maturing ribosome subunits and where in the cell these events take place. DNA/RNA sequencing studies have also begun to identify mutations in the many proteins, mRNAs, and ncRNAs related to ribosome biogenesis and translation initiation that are associated with ribosomopathies. It is well evident that the notion of one kinase phosphorylating one substrate to regulate a particular process is past. Omics technologies have revealed a variety of modifications that take place on the same protein, ranging from sumoylations, ubiquitinations, acetylations, and the most wide-spread post-translational modification, phosphorylation. Certainly, some of these modifications are determinant in the activity of the protein, and many key modifications are already known; but, the purpose/function of the majority of these modifications and their consequences are unknown. This is no more evident than in the processes of ribosome biogenesis and translation initiation. While research to date has given a basic understanding of the processes, omics technology has revealed how complex the regulation of these processes really is. The combination of modifications and the possible outcomes is infinite along with the possibility of disease-causing alterations. The evolutionary relevance of these modifications allows the cell the possibility to respond to an infinite number of environmental stresses, much the same as the immune system is designed to recognize an infinite number of antigens. This review has touched upon two key regulation pathways, PI3K-AKT-mTORC1 and PKR in ribosome biogenesis and translation, and how these pathways interact with transcription factors (MYC and p53) and splicing/RNA editing enzymes. From the data, it is evident that our knowledge of both these pathways is only touching the tip of the iceberg. Combining the information gleaned from omics studies with biochemical/molecular studies to identify the function of these modifications will be paramount to our complete understanding of these processes and the future development of therapies to a variety of diseases, many with causes that at the present remain unknown.

Author Contributions: M.P. designed the figures. W.L.B. wrote the manuscript. M.P., A.B., A.G., and I.F. checked and critiqued the manuscript.

Funding: This work was supported by grants from the Leukemia Research Foundation (to WLB), the Associazione Italiana per la Ricerca sul Cancro (AIRC-IG2015; Grant Numbers: 17137 and 22080) (to WLB and AG, respectively), Fondazione Neri (to AG), and the Del Monte Foundation (to IF).

Conflicts of Interest: The authors declare not conflict of interest. 
Abbreviations

$\begin{array}{ll}\text { AMP } & \text { Adenosine Monophosphate } \\ \text { ATF } & \text { Activating Transcription Factor } \\ \text { ATP } & \text { Adenosine Triphosphate } \\ \text { BMFD } & \text { Bone Marrow Failure Disorder } \\ \text { DBA } & \text { Diamond-Blackfan Anemia } \\ \text { DC } & \text { Dyskeratosis Congenita } \\ \text { eIF } & \text { Eukaryotic Translation Initiation Factor } \\ \text { eEF } & \text { Eukaryotic Translation Elongation Factor } \\ \text { FGF } & \text { Fibroblast Growth Factor } \\ \text { GDP } & \text { Guanosine Diphosphate } \\ \text { GTP } & \text { Guanosine Triphosphate } \\ \text { GTPase } & \text { Guanosine Triphosphatase } \\ \text { HAT } & \text { Histone Acetyltransferase } \\ \text { hnRNP } & \text { Heterogeneous Nuclear Ribonucleoprotein } \\ \text { IFN } & \text { Interferon } \\ \text { IL } & \text { Interleukin } \\ \text { IRES } & \text { Internal Ribosome Entry Site } \\ \text { MDS } & \text { Myelodysplastic Syndrome } \\ \text { mRNA } & \text { Messenger RNA } \\ \text { ncRNA } & \text { Non-coding RNA } \\ \text { PIC } & \text { Pre-Initiation Complex } \\ \text { PtdIns } & \text { Phosphatidylinositol } \\ \text { RNP } & \text { Ribonucleoprotein } \\ \text { RP } & \text { Ribosomal Protein } \\ \text { RPL } & \text { 60S Ribosomal Subunit Protein } \\ \text { RPS } & \text { 40S Ribosomal Subunit Protein } \\ \text { rDNA } & \text { Ribosomal DNA } \\ \text { rRNA } & \text { Ribosomal RNA } \\ \text { scaRNA } & \text { Small Cajal Body RNA } \\ \text { SDS } & \text { Shwachman-Diamond Syndrome } \\ \text { snRNA } & \text { Small Nuclear RNA } \\ \text { snRNP } & \text { Small Nuclear Ribonucleoprotein } \\ \text { snoRNA } & \text { Small Nucleolar RNA } \\ \text { TCS } & \text { Treacher-Collins Syndrome } \\ \text { TNF } \alpha & \text { Tumor Necrosis Factor-Alpha } \\ \text { TRRAP } & \text { Transformation/Transcription Domain-Associated Protein } \\ \text { tRNA } & \text { Transfer RNA } \\ \text { UORF } & \text { Upstream Open Reading Frame } \\ \text { VERR } & \text { Unfolded Protein Response } \\ \end{array}$

\section{References}

1. Pelletier, J.; Thomas, G.; Volarević, S. Ribosome biogenesis in cancer: New players and therapeutic avenues. Nat. Rev. Cancer 2018, 18, 51-63. [CrossRef] [PubMed]

2. Blalock, W.L.; Piazzi, M.; Gallo, A.; Bavelloni, A.; Faenza, I. RNA processing and ribosome biogenesis in bone marrow failure disorders. RNA Dis. 2017, 4, e1531. [CrossRef]

3. Kjeldgaard, N.O.; Maaloe, O.; Schaechter, M. The transition between different physiological states during balanced growth of Salmonella typhimurium. J. Gen. Microbiol. 1958, 19, 607-616. [CrossRef] [PubMed] 
4. Schaechter, M.; Maaloe, O.; Kjeldgaard, N.O. Dependency on medium and temperature of cell size and chemical composition during balanced grown of Salmonella typhimurium. J. Gen. Microbiol. 1958, 19, 592-606. [CrossRef] [PubMed]

5. Gamalinda, M.; Woolford, J.L., Jr. Paradigms of ribosome synthesis: Lessons learned from ribosomal proteins. Translation 2015, 3, e975018. [CrossRef] [PubMed]

6. Henras, A.K.; Plisson-Chastang, C.; O’Donohue, M.F.; Chakraborty, A.; Gleizes, P.E. An overview of pre-ribosomal RNA processing in eukaryotes. Wiley Interdiscip. Rev. RNA 2015, 6, 225-242. [CrossRef] [PubMed]

7. Kressler, D.; Hurt, E.; Bassler, J. Driving ribosome assembly. Biochim. Biophys. Acta 2010, 1803, $673-683$. [CrossRef]

8. van Riggelen, J.; Yetil, A.; Felsher, D.W. MYC as a regulator of ribosome biogenesis and protein synthesis. Nat. Rev. Cancer 2010, 10, 301-309. [CrossRef] [PubMed]

9. de Las Heras-Rubio, A.; Perucho, L.; Paciucci, R.; Vilardell, J.; LLeonart, M.E. Ribosomal proteins as novel players in tumorigenesis. Cancer Metastasis Rev. 2014, 33, 115-141. [CrossRef]

10. Braun, B.R.; Kassavetis, G.A.; Geiduschek, E.P. Bending of the Saccharomyces cerevisiae 5S rRNA gene in transcription factor complexes. J Biol. Chem. 1992, 267, 22562-22569.

11. Rothfels, K.; Rowland, O.; Segall, J. Zinc fingers 1 and 7 of yeast TFIIIA are essential for assembly of a functional transcription complex on the 5 S RNA gene. Nucleic Acids Res. 2007, 35, 4869-4881. [CrossRef] [PubMed]

12. Zemp, I.; Kutay, U. Nuclear export and cytoplasmic maturation of ribosomal subunits. FEBS Lett. 2007, 581, 2783-2793. [CrossRef] [PubMed]

13. Zhang, Z.; Gerstein, M. Identification and characterization of over 100 mitochondrial ribosomal protein pseudogenes in the human genome. Genomics 2003, 81, 468-480. [CrossRef]

14. Zhou, Y.; Musalgaonkar, S.; Johnson, A.W.; Taylor, D.W. Tightly-orchestrated rearrangements govern catalytic center assembly of the ribosome. Nat. Commun. 2019, 10, 958. [CrossRef]

15. Pillet, B.; Mitterer, V.; Kressler, D.; Pertschy, B. Hold on to your friends: Dedicated chaperones of ribosomal proteins: Dedicated chaperones mediate the safe transfer of ribosomal proteins to their site of pre-ribosome incorporation. Bioessays 2017, 39, 1-12. [CrossRef] [PubMed]

16. Pena, C.; Schutz, S.; Fischer, U.; Chang, Y.; Panse, V.G. Prefabrication of a ribosomal protein subcomplex essential for eukaryotic ribosome formation. Elife 2016, 5, e21755. [CrossRef] [PubMed]

17. Leidig, C.; Thoms, M.; Holdermann, I.; Bradatsch, B.; Berninghausen, O.; Bange, G.; Sinning, I.; Hurt, E.; Beckmann, R. $60 \mathrm{~S}$ ribosome biogenesis requires rotation of the $5 \mathrm{~S}$ ribonucleoprotein particle. Nat. Commun. 2014, 5, 3491. [CrossRef]

18. Kater, L.; Thoms, M.; Barrio-Garcia, C.; Cheng, J.; Ismail, S.; Ahmed, Y.L.; Bange, G.; Kressler, D.; Berninghausen, O.; Sinning, I.; et al. Visualizing the assembly pathway of nucleolar Pre-60S ribosomes. Cell 2017, 171, 1599-1610. [CrossRef]

19. Greber, B.J.; Gerhardy, S.; Leitner, A.; Leibundgut, M.; Salem, M.; Boehringer, D.; Leulliot, N.; Aebersold, R.; Panse, V.G.; Ban, N. Insertion of the biogenesis factor rei1 probes the ribosomal tunnel during 60 s maturation. Cell 2016, 164, 91-102. [CrossRef]

20. Turowski, T.W.; Tollervey, D. Cotranscriptional events in eukaryotic ribosome synthesis. Wiley Interdiscip. Rev. RNA 2015, 6, 129-139. [CrossRef]

21. Fernandez-Pevida, A.; Kressler, D.; de la Cruz, J. Processing of preribosomal RNA in Saccharomyces cerevisiae. Wiley Interdiscip. Rev. RNA 2015, 6, 191-209. [CrossRef] [PubMed]

22. Mullineux, S.T.; Lafontaine, D.L. Mapping the cleavage sites on mammalian pre-rRNAs: Where do we stand? Biochimie 2012, 94, 1521-1532. [CrossRef] [PubMed]

23. Burroughs, L.; Woolfrey, A.; Shimamura, A. Shwachman-Diamond syndrome: A review of the clinical presentation, molecular pathogenesis, diagnosis, and treatment. Hematol. Oncol. Clin. N. Am. 2009, 23, 233-248. [CrossRef] [PubMed]

24. Brina, D.; Miluzio, A.; Ricciardi, S.; Biffo, S. eIF6 anti-association activity is required for ribosome biogenesis, translational control and tumor progression. Biochim. Biophys. Acta 2015, 1849, 830-835. [CrossRef] [PubMed]

25. Danilova, N.; Gazda, H.T. Ribosomopathies: How a common root can cause a tree of pathologies. Dis. Models Mech. 2015, 8, 1013-1026. [CrossRef] 
26. Bibikova, E.; Youn, M.Y.; Danilova, N.; Ono-Uruga, Y.; Konto-Ghiorghi, Y.; Ochoa, R.; Narla, A.; Glader, B.; Lin, S.; Sakamoto, K.M. TNF-mediated inflammation represses GATA1 and activates p38 MAP kinase in RPS19-deficient hematopoietic progenitors. Blood 2014, 124, 3791-3798. [CrossRef]

27. Trinkle-Mulcahy, L.; Sleeman, J.E. The Cajal body and the nucleolus: "In a relationship" or "It's complicated"? RNA Biol. 2017, 14, 739-751. [CrossRef]

28. Leary, D.J.; Huang, S. Regulation of ribosome biogenesis within the nucleolus. FEBS Lett. 2001, 509, $145-150$. [CrossRef]

29. Fernandez, P.C.; Frank, S.R.; Wang, L.; Schroeder, M.; Liu, S.; Greene, J.; Cocito, A.; Amati, B. Genomic targets of the human c-Myc protein. Genes Dev. 2003, 17, 1115-1129. [CrossRef]

30. Frank, S.R.; Schroeder, M.; Fernandez, P.; Taubert, S.; Amati, B. Binding of c-Myc to chromatin mediates mitogen-induced acetylation of histone $\mathrm{H} 4$ and gene activation. Genes Dev. 2001, 15, 2069-2082. [CrossRef]

31. McMahon, S.B.; Wood, M.A.; Cole, M.D. The essential cofactor TRRAP recruits the histone acetyltransferase hGCN5 to c-Myc. Mol. Cell. Biol. 2000, 20, 556-562. [CrossRef]

32. Gomez-Roman, N.; Grandori, C.; Eisenman, R.N.; White, R.J. Direct activation of RNA polymerase III transcription by c-Myc. Nature 2003, 421, 290-294. [CrossRef] [PubMed]

33. Poortinga, G.; Hannan, K.M.; Snelling, H.; Walkley, C.R.; Jenkins, A.; Sharkey, K.; Wall, M.; Brandenburger, Y.; Palatsides, M.; Pearson, R.B.; et al. MAD1 and c-MYC regulate UBF and rDNA transcription during granulocyte differentiation. EMBO J. 2004, 23, 3325-3335. [CrossRef]

34. Dai, M.S.; Arnold, H.; Sun, X.X.; Sears, R.; Lu, H. Inhibition of c-Myc activity by ribosomal protein L11. EMBO J. 2007, 26, 3332-3345. [CrossRef]

35. Ginisty, H.; Amalric, F.; Bouvet, P. Nucleolin functions in the first step of ribosomal RNA processing. $E M B O$ J 1998, 17, 1476-1486. [CrossRef]

36. Watson, J.D.; Oster, S.K.; Shago, M.; Khosravi, F.; Penn, L.Z. Identifying genes regulated in a Myc-dependent manner. J. Biol. Chem. 2002, 277, 36921-36930. [CrossRef] [PubMed]

37. Schmidt, E.V. The role of c-myc in regulation of translation initiation. Oncogene 2004, 23, 3217-3221. [CrossRef] [PubMed]

38. Barna, M.; Pusic, A.; Zollo, O.; Costa, M.; Kondrashov, N.; Rego, E.; Rao, P.H.; Ruggero, D. Suppression of Myc oncogenic activity by ribosomal protein haploinsufficiency. Nature 2008, 456, 971-975. [CrossRef] [PubMed]

39. Blalock, W.L.; Piazzi, M.; Bavelloni, A.; Raffini, M.; Faenza, I.; D'Angelo, A.; Cocco, L. Identification of the PKR nuclear interactome reveals roles in ribosome biogenesis, mRNA processing and cell division. J. Cell. Physiol. 2014, 229, 1047-1060. [CrossRef] [PubMed]

40. Hann, S.R.; Dixit, M.; Sears, R.C.; Sealy, L. The alternatively initiated c-Myc proteins differentially regulate transcription through a noncanonical DNA-binding site. Genes Dev. 1994, 8, 2441-2452. [CrossRef] [PubMed]

41. Franke, T.F. PI3K/Akt: Getting it right matters. Oncogene 2008, 27, 6473-6488. [CrossRef] [PubMed]

42. Hannan, K.M.; Sanij, E.; Hein, N.; Hannan, R.D.; Pearson, R.B. Signaling to the ribosome in cancer-It is more than just mTORC1. IUBMB Life 2011, 63, 79-85. [CrossRef]

43. Papa, A.; Pandolfi, P.P. The PTEN(-)PI3K Axis in Cancer. Biomolecules 2019, 9, 153. [CrossRef] [PubMed]

44. Sarbassov, D.D.; Guertin, D.A.; Ali, S.M.; Sabatini, D.M. Phosphorylation and regulation of Akt/PKB by the rictor-mTOR complex. Science 2005, 307, 1098-1101. [CrossRef] [PubMed]

45. Gonzalez, E.; McGraw, T.E. The Akt kinases: Isoform specificity in metabolism and cancer. Cell Cycle 2009, 8, 2502-2508. [CrossRef] [PubMed]

46. Cohen, M.M., Jr. The AKT genes and their roles in various disorders. Am. J. Med. Genet. A 2013, 161A, 2931-2937. [CrossRef]

47. Memmott, R.M.; Dennis, P.A. Akt-dependent and -independent mechanisms of mTOR regulation in cancer. Cell. Signal. 2009, 21, 656-664. [CrossRef]

48. Boultwood, J.; Yip, B.H.; Vuppusetty, C.; Pellagatti, A.; Wainscoat, J.S. Activation of the mTOR pathway by the amino acid (L)-leucine in the 5q- syndrome and other ribosomopathies. Adv. Biol. Regul. 2013, 53, 8-17. [CrossRef]

49. Kim, E.; Goraksha-Hicks, P.; Li, L.; Neufeld, T.P.; Guan, K.L. Regulation of TORC1 by Rag GTPases in nutrient response. Nat. Cell Biol. 2008, 10, 935-945. [CrossRef] 
50. Sancak, Y.; Bar-Peled, L.; Zoncu, R.; Markhard, A.L.; Nada, S.; Sabatini, D.M. Ragulator-Rag complex targets mTORC1 to the lysosomal surface and is necessary for its activation by amino acids. Cell 2010, 141, 290-303. [CrossRef]

51. Nicklin, P.; Bergman, P.; Zhang, B.; Triantafellow, E.; Wang, H.; Nyfeler, B.; Yang, H.; Hild, M.; Kung, C.; Wilson, C.; et al. Bidirectional transport of amino acids regulates mTOR and autophagy. Cell 2009, 136, 521-534. [CrossRef] [PubMed]

52. Han, J.M.; Jeong, S.J.; Park, M.C.; Kim, G.; Kwon, N.H.; Kim, H.K.; Ha, S.H.; Ryu, S.H.; Kim, S. Leucyl-tRNA synthetase is an intracellular leucine sensor for the mTORC1-signaling pathway. Cell 2012, 149, 410-424. [CrossRef]

53. Inoki, K.; Zhu, T.; Guan, K.L. TSC2 mediates cellular energy response to control cell growth and survival. Cell 2003, 115, 577-590. [CrossRef]

54. Gwinn, D.M.; Shackelford, D.B.; Egan, D.F.; Mihaylova, M.M.; Mery, A.; Vasquez, D.S.; Turk, B.E.; Shaw, R.J. AMPK phosphorylation of raptor mediates a metabolic checkpoint. Mol. Cell 2008, 30, 214-226. [CrossRef] [PubMed]

55. Yang, G.; Murashige, D.S.; Humphrey, S.J.; James, D.E. A positive feedback loop between Akt and mTORC2 via SIN1 phosphorylation. Cell Rep. 2015, 12, 937-943. [CrossRef]

56. Blalock, W.L.; Bavelloni, A.; Piazzi, M.; Faenza, I.; Cocco, L. A role for PKR in hematologic malignancies. J. Cell. Physiol. 2010, 223, 572-591. [CrossRef]

57. Dorrello, N.V.; Peschiaroli, A.; Guardavaccaro, D.; Colburn, N.H.; Sherman, N.E.; Pagano, M. S6K1- and betaTRCP-mediated degradation of PDCD4 promotes protein translation and cell growth. Science 2006, 314, 467-471. [CrossRef]

58. Galan, J.A.; Geraghty, K.M.; Lavoie, G.; Kanshin, E.; Tcherkezian, J.; Calabrese, V.; Jeschke, G.R.; Turk, B.E.; Ballif, B.A.; Blenis, J.; et al. Phosphoproteomic analysis identifies the tumor suppressor PDCD4 as a RSK substrate negatively regulated by 14-3-3. Proc. Natl. Acad. Sci. USA 2014, 111, E2918-E2927. [CrossRef]

59. Raught, B.; Peiretti, F.; Gingras, A.C.; Livingstone, M.; Shahbazian, D.; Mayeur, G.L.; Polakiewicz, R.D.; Sonenberg, N.; Hershey, J.W. Phosphorylation of eucaryotic translation initiation factor 4B Ser422 is modulated by S6 kinases. EMBO J. 2004, 23, 1761-1769. [CrossRef]

60. Richardson, C.J.; Broenstrup, M.; Fingar, D.C.; Julich, K.; Ballif, B.A.; Gygi, S.; Blenis, J. SKAR is a specific target of S6 kinase 1 in cell growth control. Curr. Biol. 2004, 14, 1540-1549. [CrossRef]

61. Martineau, Y.; Wang, X.; Alain, T.; Petroulakis, E.; Shahbazian, D.; Fabre, B.; Bousquet-Dubouch, M.P.; Monsarrat, B.; Pyronnet, S.; Sonenberg, N. Control of Paip1-eukayrotic translation initiation factor 3 interaction by amino acids through S6 kinase. Mol. Cell. Biol. 2014, 34, 1046-1053. [CrossRef] [PubMed]

62. Zhu, J.; Blenis, J.; Yuan, J. Activation of PI3K/Akt and MAPK pathways regulates Myc-mediated transcription by phosphorylating and promoting the degradation of Mad1. Proc. Natl. Acad. Sci. USA 2008, 105, 6584-6589. [CrossRef] [PubMed]

63. Zhang, Y.; Stefanovic, B. Akt mediated phosphorylation of LARP6; critical step in biosynthesis of type I collagen. Sci. Rep. 2016, 6, 22597. [CrossRef]

64. Fonseca, B.D.; Lahr, R.M.; Damgaard, C.K.; Alain, T.; Berman, A.J. LARP1 on TOP of ribosome production. Wiley Interdiscip. Rev. RNA 2018, 9, e1480. [CrossRef] [PubMed]

65. Zhang, Y.; Stefanovic, B. mTORC1 phosphorylates LARP6 to stimulate type I collagen expression. Sci. Rep. 2017, 7, 41173. [CrossRef] [PubMed]

66. Innes, F.; Ramsbottom, B.; White, R.J. A test of the model that RNA polymerase III transcription is regulated by selective induction of the $110 \mathrm{kDa}$ subunit of TFIIIC. Nucleic Acids Res. 2006, 34, 3399-3407. [CrossRef] [PubMed]

67. Shor, B.; Wu, J.; Shakey, Q.; Toral-Barza, L.; Shi, C.; Follettie, M.; Yu, K. Requirement of the mTOR kinase for the regulation of Maf1 phosphorylation and control of RNA polymerase III-dependent transcription in cancer cells. J. Biol. Chem. 2010, 285, 15380-15392. [CrossRef]

68. Wang, X.; Li, W.; Williams, M.; Terada, N.; Alessi, D.R.; Proud, C.G. Regulation of elongation factor 2 kinase by p90(RSK1) and p70 S6 kinase. EMBO J. 2001, 20, 4370-4379. [CrossRef] [PubMed]

69. Ruvinsky, I.; Meyuhas, O. Ribosomal protein S6 phosphorylation: From protein synthesis to cell size. Trends Biochem. Sci. 2006, 31, 342-348. [CrossRef] 
70. Roux, P.P.; Shahbazian, D.; Vu, H.; Holz, M.K.; Cohen, M.S.; Taunton, J.; Sonenberg, N.; Blenis, J. RAS/ERK signaling promotes site-specific ribosomal protein $\mathrm{S} 6$ phosphorylation via RSK and stimulates cap-dependent translation. J. Biol. Chem. 2007, 282, 14056-14064. [CrossRef]

71. Duan, S.; Skaar, J.R.; Kuchay, S.; Toschi, A.; Kanarek, N.; Ben-Neriah, Y.; Pagano, M. mTOR generates an auto-amplification loop by triggering the betaTrCP- and CK1alpha-dependent degradation of DEPTOR. Mol. Cell 2011, 44, 317-324. [CrossRef]

72. Dibble, C.C.; Asara, J.M.; Manning, B.D. Characterization of Rictor phosphorylation sites reveals direct regulation of mTOR complex 2 by S6K1. Mol. Cell. Biol. 2009, 29, 5657-5670. [CrossRef] [PubMed]

73. Holz, M.K.; Blenis, J. Identification of S6 kinase 1 as a novel mammalian target of rapamycin (mTOR)-phosphorylating kinase. J. Biol. Chem. 2005, 280, 26089-26093. [CrossRef] [PubMed]

74. Bavelloni, A.; Focaccia, E.; Piazzi, M.; Raffini, M.; Cesarini, V.; Tomaselli, S.; Orsini, A.; Ratti, S.; Faenza, I.; Cocco, L.; et al. AKT-dependent phosphorylation of the adenosine deaminases ADAR-1 and -2 inhibits deaminase activity. FASEB J. 2019, fj201800490RR. [CrossRef]

75. Knudsen, E.S.; Knudsen, K.E. Tailoring to RB: Tumour suppressor status and therapeutic response. Nat. Rev. Cancer 2008, 8, 714-724. [CrossRef] [PubMed]

76. White, R.J.; Trouche, D.; Martin, K.; Jackson, S.P.; Kouzarides, T. Repression of RNA polymerase III transcription by the retinoblastoma protein. Nature 1996, 382, 88-90. [CrossRef]

77. Cavanaugh, A.H.; Hempel, W.M.; Taylor, L.J.; Rogalsky, V.; Todorov, G.; Rothblum, L.I. Activity of RNA polymerase I transcription factor UBF blocked by Rb gene product. Nature 1995, 374, 177-180. [CrossRef]

78. Lessard, F.; Morin, F.; Ivanchuk, S.; Langlois, F.; Stefanovsky, V.; Rutka, J.; Moss, T. The ARF tumor suppressor controls ribosome biogenesis by regulating the RNA polymerase I transcription factor TTF-I. Mol. Cell 2010, 38, 539-550. [CrossRef]

79. James, A.; Wang, Y.; Raje, H.; Rosby, R.; DiMario, P. Nucleolar stress with and without p53. Nucleus 2014, 5, 402-426. [CrossRef]

80. Brady, S.N.; Yu, Y.; Maggi, L.B., Jr.; Weber, J.D. ARF impedes NPM/B23 shuttling in an Mdm2-sensitive tumor suppressor pathway. Mol. Cell. Biol. 2004, 24, 9327-9338. [CrossRef]

81. Itahana, K.; Bhat, K.P.; Jin, A.; Itahana, Y.; Hawke, D.; Kobayashi, R.; Zhang, Y. Tumor suppressor ARF degrades B23, a nucleolar protein involved in ribosome biogenesis and cell proliferation. Mol. Cell 2003, 12, 1151-1164. [CrossRef]

82. Llanos, S.; Clark, P.A.; Rowe, J.; Peters, G. Stabilization of p53 by p14ARF without relocation of MDM2 to the nucleolus. Nat. Cell Biol. 2001, 3, 445-452. [CrossRef]

83. Weber, J.D.; Taylor, L.J.; Roussel, M.F.; Sherr, C.J.; Bar-Sagi, D. Nucleolar Arf sequesters Mdm2 and activates p53. Nat. Cell Biol. 1999, 1, 20-26. [CrossRef]

84. Garcia, M.A.; Collado, M.; Munoz-Fontela, C.; Matheu, A.; Marcos-Villar, L.; Arroyo, J.; Esteban, M.; Serrano, M.; Rivas, C. Antiviral action of the tumor suppressor ARF. EMBO J. 2006, 25, 4284-4292. [CrossRef] [PubMed]

85. Itahana, Y.; Itahana, K. Emerging roles of p53 family members in glucose metabolism. Int. J. Mol. Sci. 2018, 19, 776. [CrossRef]

86. Cairns, C.A.; White, R.J. p53 is a general repressor of RNA polymerase III transcription. EMBO J. 1998, 17, 3112-3123. [CrossRef] [PubMed]

87. Zhai, W.; Comai, L. Repression of RNA polymerase I transcription by the tumor suppressor p53. Mol. Cell. Biol. 2000, 20, 5930-5938. [CrossRef]

88. Orsolic, I.; Jurada, D.; Pullen, N.; Oren, M.; Eliopoulos, A.G.; Volarevic, S. The relationship between the nucleolus and cancer: Current evidence and emerging paradigms. Semin. Cancer Biol. 2016, 37, 36-50. [CrossRef] [PubMed]

89. Dai, M.S.; Sun, X.X.; Lu, H. Aberrant expression of nucleostemin activates p53 and induces cell cycle arrest via inhibition of MDM2. Mol. Cell. Biol. 2008, 28, 4365-4376. [CrossRef]

90. Bursac, S.; Brdovcak, M.C.; Donati, G.; Volarevic, S. Activation of the tumor suppressor p53 upon impairment of ribosome biogenesis. Biochim. Biophys. Acta 2014, 1842, 817-830. [CrossRef]

91. Sloan, K.E.; Bohnsack, M.T.; Watkins, N.J. The 5S RNP couples p53 homeostasis to ribosome biogenesis and nucleolar stress. Cell Rep. 2013, 5, 237-247. [CrossRef]

92. Hinnebusch, A.G. Structural insights into the mechanism of scanning and start codon recognition in eukaryotic translation initiation. Trends Biochem. Sci. 2017, 42, 589-611. [CrossRef] [PubMed] 
93. Hinnebusch, A.G.; Lorsch, J.R. The mechanism of eukaryotic translation initiation: New insights and challenges. Cold Spring Harb. Perspect. Biol. 2012, 4, a011544. [CrossRef] [PubMed]

94. Sonenberg, N.; Hinnebusch, A.G. Regulation of translation initiation in eukaryotes: Mechanisms and biological targets. Cell 2009, 136, 731-745. [CrossRef]

95. Wek, R.C.; Jiang, H.Y.; Anthony, T.G. Coping with stress: eIF2 kinases and translational control. Biochem. Soc. Trans. 2006, 34, 7-11. [CrossRef] [PubMed]

96. Kimball, S.R.; Clemens, M.J.; Tilleray, V.J.; Wek, R.C.; Horetsky, R.L.; Jefferson, L.S. The double-stranded RNA-activated protein kinase PKR is dispensable for regulation of translation initiation in response to either calcium mobilization from the endoplasmic reticulum or essential amino acid starvation. Biochem. Biophys. Res. Commun. 2001, 280, 293-300. [CrossRef]

97. Shi, Y.; Vattem, K.M.; Sood, R.; An, J.; Liang, J.; Stramm, L.; Wek, R.C. Identification and characterization of pancreatic eukaryotic initiation factor 2 alpha-subunit kinase, PEK, involved in translational control. Mol. Cell. Biol. 1998, 18, 7499-7509. [CrossRef]

98. Mounir, Z.; Krishnamoorthy, J.L.; Wang, S.; Papadopoulou, B.; Campbell, S.; Muller, W.J.; Hatzoglou, M.; Koromilas, A.E. Akt determines cell fate through inhibition of the PERK-eIF2alpha phosphorylation pathway. Sci. Signal 2011, 4, ra62. [CrossRef]

99. Berlanga, J.J.; Santoyo, J.; De Haro, C. Characterization of a mammalian homolog of the GCN2 eukaryotic initiation factor 2alpha kinase. Eur. J. Biochem. 1999, 265, 754-762. [CrossRef]

100. Chen, J.J. Regulation of protein synthesis by the heme-regulated eIF2alpha kinase: Relevance to anemias. Blood 2007, 109, 2693-2699. [CrossRef]

101. Garcia, M.A.; Gil, J.; Ventoso, I.; Guerra, S.; Domingo, E.; Rivas, C.; Esteban, M. Impact of protein kinase PKR in cell biology: From antiviral to antiproliferative action. Microbiol. Mol. Biol. Rev. 2006, 70, 1032-1060. [CrossRef]

102. Williams, B.R. PKR; a sentinel kinase for cellular stress. Oncogene 1999, 18, 6112-6120. [CrossRef] [PubMed]

103. Hamanaka, R.B.; Bennett, B.S.; Cullinan, S.B.; Diehl, J.A. PERK and GCN2 contribute to eIF2alpha phosphorylation and cell cycle arrest after activation of the unfolded protein response pathway. Mol. Biol. Cell 2005, 16, 5493-5501. [CrossRef] [PubMed]

104. Ito, T.; Warnken, S.P.; May, W.S. Protein synthesis inhibition by flavonoids: Roles of eukaryotic initiation factor 2alpha kinases. Biochem. Biophys. Res. Commun. 1999, 265, 589-594. [CrossRef] [PubMed]

105. Pervin, S.; Tran, A.H.; Zekavati, S.; Fukuto, J.M.; Singh, R.; Chaudhuri, G. Increased susceptibility of breast cancer cells to stress mediated inhibition of protein synthesis. Cancer Res. 2008, 68, 4862-4874. [CrossRef]

106. Blalock, W.L.; Bavelloni, A.; Piazzi, M.; Tagliavini, F.; Faenza, I.; Martelli, A.M.; Follo, M.Y.; Cocco, L. Multiple forms of PKR present in the nuclei of acute leukemia cells represent an active kinase that is responsive to stress. Leukemia 2011, 25, 236-245. [CrossRef]

107. Tafforeau, L. About the ribosomal biogenesis in human. Med. Sci. 2015, 31, 622-628. [CrossRef]

108. Tomecki, R.; Sikorski, P.J.; Zakrzewska-Placzek, M. Comparison of preribosomal RNA processing pathways in yeast, plant and human cells-Focus on coordinated action of endo- and exoribonucleases. FEBS Lett. 2017, 591, 1801-1850. [CrossRef]

109. Fernandez, J.; Yaman, I.; Merrick, W.C.; Koromilas, A.; Wek, R.C.; Sood, R.; Hensold, J.; Hatzoglou, M. Regulation of internal ribosome entry site-mediated translation by eukaryotic initiation factor-2alpha phosphorylation and translation of a small upstream open reading frame. J. Biol. Chem. 2002, 277, 2050-2058. [CrossRef]

110. Yaman, I.; Fernandez, J.; Liu, H.; Caprara, M.; Komar, A.A.; Koromilas, A.E.; Zhou, L.; Snider, M.D.; Scheuner, D.; Kaufman, R.J.; et al. The zipper model of translational control: A small upstream ORF is the switch that controls structural remodeling of an mRNA leader. Cell 2003, 113, 519-531. [CrossRef]

111. Gerlitz, G.; Jagus, R.; Elroy-Stein, O. Phosphorylation of initiation factor-2 alpha is required for activation of internal translation initiation during cell differentiation. Eur. J. Biochem. 2002, 269, 2810-2819. [CrossRef] [PubMed]

112. Donze, O.; Deng, J.; Curran, J.; Sladek, R.; Picard, D.; Sonenberg, N. The protein kinase PKR: A molecular clock that sequentially activates survival and death programs. EMBO J. 2004, 23, 564-571. [CrossRef] [PubMed] 
113. Sanz, M.A.; Redondo, N.; Garcia-Moreno, M.; Carrasco, L. Phosphorylation of eIF2alpha is responsible for the failure of the picornavirus internal ribosome entry site to direct translation from Sindbis virus replicons. J. Gen. Virol. 2013, 94, 796-806. [CrossRef] [PubMed]

114. Stoneley, M.; Willis, A.E. Cellular internal ribosome entry segments: Structures, trans-acting factors and regulation of gene expression. Oncogene 2004, 23, 3200-3207. [CrossRef]

115. Aggarwal, B.B.; Shishodia, S.; Takada, Y.; Jackson-Bernitsas, D.; Ahn, K.S.; Sethi, G.; Ichikawa, H. TNF blockade: An inflammatory issue. Ernst Schering Res. Found. Workshop 2006, 161-186. [CrossRef]

116. Aggarwal, B.B.; Shishodia, S.; Sandur, S.K.; Pandey, M.K.; Sethi, G. Inflammation and cancer: How hot is the link? Biochem. Pharmacol. 2006, 72, 1605-1621. [CrossRef]

117. Koschmieder, S.; D’Alo, F.; Radomska, H.; Schoneich, C.; Chang, J.S.; Konopleva, M.; Kobayashi, S.; Levantini, E.; Suh, N.; Di Ruscio, A.; et al. CDDO induces granulocytic differentiation of myeloid leukemic blasts through translational up-regulation of p42 CCAAT enhancer binding protein alpha. Blood 2007, 110, 3695-3705. [CrossRef]

118. Lee, Y.Y.; Cevallos, R.C.; Jan, E. An upstream open reading frame regulates translation of GADD34 during cellular stresses that induce eIF2alpha phosphorylation. J. Biol. Chem. 2009, 284, 6661-6673. [CrossRef]

119. van den Beucken, T.; Magagnin, M.G.; Savelkouls, K.; Lambin, P.; Koritzinsky, M.; Wouters, B.G. Regulation of Cited 2 expression provides a functional link between translational and transcriptional responses during hypoxia. Radiother. Oncol. 2007, 83, 346-352. [CrossRef]

120. Hofmann, W.K.; de Vos, S.; Komor, M.; Hoelzer, D.; Wachsman, W.; Koeffler, H.P. Characterization of gene expression of CD34+ cells from normal and myelodysplastic bone marrow. Blood 2002, 100, 3553-3560. [CrossRef]

121. Yamaguchi, K.; Lee, S.H.; Kim, J.S.; Wimalasena, J.; Kitajima, S.; Baek, S.J. Activating transcription factor 3 and early growth response 1 are the novel targets of LY294002 in a phosphatidylinositol 3-kinase-independent pathway. Cancer Res. 2006, 66, 2376-2384. [CrossRef] [PubMed]

122. Wang, A.; Arantes, S.; Yan, L.; Kiguchi, K.; McArthur, M.J.; Sahin, A.; Thames, H.D.; Aldaz, C.M.; Macleod, M.C. The transcription factor ATF3 acts as an oncogene in mouse mammary tumorigenesis. BMC Cancer 2008, 8, 268. [CrossRef] [PubMed]

123. Janz, M.; Hummel, M.; Truss, M.; Wollert-Wulf, B.; Mathas, S.; Johrens, K.; Hagemeier, C.; Bommert, K.; Stein, H.; Dorken, B.; et al. Classical Hodgkin lymphoma is characterized by high constitutive expression of activating transcription factor 3 (ATF3), which promotes viability of Hodgkin/Reed-Sternberg cells. Blood 2006, 107, 2536-2539. [CrossRef]

124. Calkhoven, C.F.; Muller, C.; Leutz, A. Translational control of C/EBPalpha and C/EBPbeta isoform expression. Genes Dev. 2000, 14, 1920-1932. [PubMed]

125. Nerlov, C. The C/EBP family of transcription factors: A paradigm for interaction between gene expression and proliferation control. Trends Cell Biol. 2007, 17, 318-324. [CrossRef] [PubMed]

126. Zhang, D.E.; Zhang, P.; Wang, N.D.; Hetherington, C.J.; Darlington, G.J.; Tenen, D.G. Absence of granulocyte colony-stimulating factor signaling and neutrophil development in CCAAT enhancer binding protein alpha-deficient mice. Proc. Natl. Acad. Sci. USA 1997, 94, 569-574. [CrossRef] [PubMed]

127. Akasaka, T.; Balasas, T.; Russell, L.J.; Sugimoto, K.J.; Majid, A.; Walewska, R.; Karran, E.L.; Brown, D.G.; Cain, K.; Harder, L.; et al. Five members of the CEBP transcription factor family are targeted by recurrent IGH translocations in B-cell precursor acute lymphoblastic leukemia (BCP-ALL). Blood 2007, 109, 3451-3461. [CrossRef] [PubMed]

128. Chapiro, E.; Russell, L.; Radford-Weiss, I.; Bastard, C.; Lessard, M.; Struski, S.; Cave, H.; Fert-Ferrer, S.; Barin, C.; Maarek, O.; et al. Overexpression of CEBPA resulting from the translocation $t(14 ; 19)(q 32 ; \mathrm{q} 13)$ of human precursor B acute lymphoblastic leukemia. Blood 2006, 108, 3560-3563. [CrossRef] [PubMed]

129. Geletu, M.; Balkhi, M.Y.; Peer Zada, A.A.; Christopeit, M.; Pulikkan, J.A.; Trivedi, A.K.; Tenen, D.G.; Behre, G. Target proteins of C/EBPalphap30 in AML: C/EBPalphap30 enhances sumoylation of C/EBPalphap42 via up-regulation of Ubc9. Blood 2007, 110, 3301-3309. [CrossRef]

130. Zhu, S.; Yoon, K.; Sterneck, E.; Johnson, P.F.; Smart, R.C. CCAAT/enhancer binding protein-beta is a mediator of keratinocyte survival and skin tumorigenesis involving oncogenic Ras signaling. Proc. Natl. Acad. Sci. USA 2002, 99, 207-212. [CrossRef] 
131. Sterneck, E.; Zhu, S.; Ramirez, A.; Jorcano, J.L.; Smart, R.C. Conditional ablation of C/EBP beta demonstrates its keratinocyte-specific requirement for cell survival and mouse skin tumorigenesis. Oncogene 2006, 25, 1272-1276. [CrossRef] [PubMed]

132. Ramana, C.V.; Grammatikakis, N.; Chernov, M.; Nguyen, H.; Goh, K.C.; Williams, B.R.; Stark, G.R. Regulation of c-myc expression by IFN-gamma through Stat1-dependent and -independent pathways. EMBO J. 2000, 19, 263-272. [CrossRef] [PubMed]

133. Takada, Y.; Ichikawa, H.; Pataer, A.; Swisher, S.; Aggarwal, B.B. Genetic deletion of PKR abrogates TNF-induced activation of IkappaBalpha kinase, JNK, Akt and cell proliferation but potentiates p44/p42 MAPK and p38 MAPK activation. Oncogene 2007, 26, 1201-1212. [CrossRef] [PubMed]

134. Blalock, W.L.; Grimaldi, C.; Fala, F.; Follo, M.; Horn, S.; Basecke, J.; Martinelli, G.; Cocco, L.; Martelli, A.M. PKR activity is required for acute leukemic cell maintenance and growth: A role for PKR-mediated phosphatase activity to regulate GSK-3 phosphorylation. J. Cell. Physiol. 2009, 221, 232-241. [CrossRef] [PubMed]

135. Bose, A.; Mouton-Liger, F.; Paquet, C.; Mazot, P.; Vigny, M.; Gray, F.; Hugon, J. Modulation of tau phosphorylation by the kinase PKR: Implications in Alzheimer's disease. Brain Pathol. 2011, 21, 189-200. [CrossRef]

136. Proud, C.G. eIF2 and the control of cell physiology. Semin. Cell Dev. Biol. 2005, 16, 3-12. [CrossRef]

137. Wang, X.; Paulin, F.E.; Campbell, L.E.; Gomez, E.; O’Brien, K.; Morrice, N.; Proud, C.G. Eukaryotic initiation factor 2B: Identification of multiple phosphorylation sites in the epsilon-subunit and their functions in vivo. EMBO J. 2001, 20, 4349-4359. [CrossRef]

138. Kubica, N.; Jefferson, L.S.; Kimball, S.R. Eukaryotic initiation factor 2B and its role in alterations in mRNA translation that occur under a number of pathophysiological and physiological conditions. Prog. Nucleic Acid Res. Mol. Biol. 2006, 81, 271-296. [CrossRef]

139. Willis, A.E. Translational control of growth factor and proto-oncogene expression. Int. J. Biochem. Cell Biol. 1999, 31, 73-86. [CrossRef]

140. van den Beucken, T.; Koritzinsky, M.; Wouters, B.G. Translational control of gene expression during hypoxia. Cancer Biol. Ther. 2006, 5, 749-755. [CrossRef]

141. Spriggs, K.A.; Bushell, M.; Mitchell, S.A.; Willis, A.E. Internal ribosome entry segment-mediated translation during apoptosis: The role of IRES-trans-acting factors. Cell Death Differ. 2005, 12, 585-591. [CrossRef] [PubMed]

142. Baltzis, D.; Pluquet, O.; Papadakis, A.I.; Kazemi, S.; Qu, L.K.; Koromilas, A.E. The eIF2alpha kinases PERK and PKR activate glycogen synthase kinase 3 to promote the proteasomal degradation of p53. J. Biol. Chem. 2007, 282, 31675-31687. [CrossRef] [PubMed]

143. Zhou, H.R.; He, K.; Landgraf, J.; Pan, X.; Pestka, J.J. Direct activation of ribosome-associated double-stranded RNA-dependent protein kinase (PKR) by deoxynivalenol, anisomycin and ricin: A new model for ribotoxic stress response induction. Toxins 2014, 6, 3406-3425. [CrossRef]

144. Wang, Y.; Liu, J.; Huang, B.O.; Xu, Y.M.; Li, J.; Huang, L.F.; Lin, J.; Zhang, J.; Min, Q.H.; Yang, W.M.; et al. Mechanism of alternative splicing and its regulation. Biomed. Rep. 2015, 3, 152-158. [CrossRef] [PubMed]

145. Baralle, D.; Buratti, E. RNA splicing in human disease and in the clinic. Clin. Sci. 2017, 131, 355-368. [CrossRef] [PubMed]

146. Haferlach, T.; Nagata, Y.; Grossmann, V.; Okuno, Y.; Bacher, U.; Nagae, G.; Schnittger, S.; Sanada, M.; Kon, A.; Alpermann, T.; et al. Landscape of genetic lesions in 944 patients with myelodysplastic syndromes. Leukemia 2014, 28, 241-247. [CrossRef] [PubMed]

147. Papaemmanuil, E.; Gerstung, M.; Malcovati, L.; Tauro, S.; Gundem, G.; Van Loo, P.; Yoon, C.J.; Ellis, P.; Wedge, D.C.; Pellagatti, A.; et al. Clinical and biological implications of driver mutations in myelodysplastic syndromes. Blood 2013, 122, 3616-3627. [CrossRef] [PubMed]

148. Yoshida, K.; Sanada, M.; Shiraishi, Y.; Nowak, D.; Nagata, Y.; Yamamoto, R.; Sato, Y.; Sato-Otsubo, A.; Kon, A.; Nagasaki, M.; et al. Frequent pathway mutations of splicing machinery in myelodysplasia. Nature 2011, 478, 64-69. [CrossRef]

149. Rendleman, J.; Cheng, Z.; Maity, S.; Kastelic, N.; Munschauer, M.; Allgoewer, K.; Teo, G.; Zhang, Y.B.M.; Lei, A.; Parker, B.; et al. New insights into the cellular temporal response to proteostatic stress. Elife 2018, 7, e39054. [CrossRef] [PubMed]

150. Mei, H.; Wang, Y.; Fan, J.; Lin, Z. Alternative splicing of S6K1 promotes non-small cell lung cancer survival. Tumor Biol. 2016, 37, 13369-13376. [CrossRef] 
151. Mrvova, S.; Frydryskova, K.; Pospisek, M.; Vopalensky, V.; Masek, T. Major splice variants and multiple polyadenylation site utilization in mRNAs encoding human translation initiation factors eIF4E1 and eIF4E3 regulate the translational regulators? Mol. Genet. Genom. 2018, 293, 167-186. [CrossRef] [PubMed]

152. Liu, X.N.; Yuan, J.H.; Wang, T.T.; Pan, W.; Sun, S.H. An alternative POLDIP3 transcript promotes hepatocellular carcinoma progression. Biomed. Pharmacother. 2017, 89, 276-283. [CrossRef] [PubMed]

153. Gupta, V.; Warner, J.R. Ribosome-omics of the human ribosome. RNA 2014, 20, 1004-1013. [CrossRef] [PubMed]

154. Plocik, A.M.; Guthrie, C. Diverse forms of RPS9 splicing are part of an evolving autoregulatory circuit. PLoS Genet. 2012, 8, e1002620. [CrossRef] [PubMed]

155. Carlston, C.M.; Afify, Z.A.; Palumbos, J.C.; Bagley, H.; Barbagelata, C.; Wooderchak-Donahue, W.L.; Mao, R.; Carey, J.C. Variable expressivity and incomplete penetrance in a large family with non-classical Diamond-Blackfan anemia associated with ribosomal protein L11 splicing variant. Am. J. Med. Genet. Part A 2017, 173, 2622-2627. [CrossRef] [PubMed]

156. Aviner, R.; Hofmann, S.; Elman, T.; Shenoy, A.; Geiger, T.; Elkon, R.; Ehrlich, M.; Elroy-Stein, O. Proteomic analysis of polyribosomes identifies splicing factors as potential regulators of translation during mitosis. Nucleic Acids Res. 2017, 45, 5945-5957. [CrossRef]

157. Liu, L.; Luo, C.; Luo, Y.; Chen, L.; Liu, Y.; Wang, Y.; Han, J.; Zhang, Y.; Wei, N.; Xie, Z.; et al. MRPL33 and its splicing regulator hnRNPK are required for mitochondria function and implicated in tumor progression. Oncogene 2018, 37, 86-94. [CrossRef]

158. Ogawa, S. Splicing factor mutations in myelodysplasia. Int. J. Hematol. 2012, 96, 438-442. [CrossRef]

159. Yang, B.; Li, X.; Lei, L.; Chen, J. APOBEC: From mutator to editor. J. Genet. Genom. 2017, 44, $423-437$. [CrossRef]

160. Nishikura, K. A-to-I editing of coding and non-coding RNAs by ADARs. Nat. Rev. Mol. Cell Biol. 2016, 17, 83-96. [CrossRef]

161. Eifler, T.; Pokharel, S.; Beal, P.A. RNA-Seq analysis identifies a novel set of editing substrates for human ADAR2 present in Saccharomyces cerevisiae. Biochemistry 2013, 52, 7857-7869. [CrossRef] [PubMed]

162. Eisenberg, E.; Nemzer, S.; Kinar, Y.; Sorek, R.; Rechavi, G.; Levanon, E.Y. Is abundant A-to-I RNA editing primate-specific? Trends Genet. 2005, 21, 77-81. [CrossRef] [PubMed]

163. Keegan, L.P.; Leroy, A.; Sproul, D.; O'Connell, M.A. Adenosine deaminases acting on RNA (ADARs): RNA-editing enzymes. Genome Biol. 2004, 5, 209. [CrossRef]

164. Torres, A.G.; Pineyro, D.; Filonava, L.; Stracker, T.H.; Batlle, E.; Ribas de Pouplana, L. A-to-I editing on tRNAs: Biochemical, biological and evolutionary implications. FEBS Lett. 2014, 588, 4279-4286. [CrossRef] [PubMed]

165. Lim, V.I.; Curran, J.F. Analysis of codon: Anticodon interactions within the ribosome provides new insights into codon reading and the genetic code structure. RNA 2001, 7, 942-957. [CrossRef] [PubMed]

166. Curran, J.F. Decoding with the A: I wobble pair is inefficient. Nucleic Acids Res. 1995, 23, 683-688. [CrossRef]

167. Keegan, L.; Khan, A.; Vukic, D.; O'Connell, M. ADAR RNA editing below the backbone. RNA 2017, 23, 1317-1328. [CrossRef] [PubMed]

168. Gallo, A.; Vukic, D.; Michalik, D.; O'Connell, M.A.; Keegan, L.P. ADAR RNA editing in human disease; more to it than meets the I. Hum. Genet. 2017, 136, 1265-1278. [CrossRef]

169. Patterson, J.B.; Samuel, C.E. Expression and regulation by interferon of a double-stranded-RNA-specific adenosine deaminase from human cells: Evidence for two forms of the deaminase. Mol. Cell. Biol. 1995, 15, 5376-5388. [CrossRef] [PubMed]

170. George, C.X.; Wagner, M.V.; Samuel, C.E. Expression of interferon-inducible RNA adenosine deaminase ADAR1 during pathogen infection and mouse embryo development involves tissue-selective promoter utilization and alternative splicing. J. Biol. Chem. 2005, 280, 15020-15028. [CrossRef] [PubMed]

171. Gerber, A.; O'Connell, M.A.; Keller, W. Two forms of human double-stranded RNA-specific editase 1 (hRED1) generated by the insertion of an Alu cassette. RNA 1997, 3, 453-463.

172. Sansam, C.L.; Wells, K.S.; Emeson, R.B. Modulation of RNA editing by functional nucleolar sequestration of ADAR2. Proc. Natl. Acad. Sci. USA 2003, 100, 14018-14023. [CrossRef] [PubMed]

173. Sakurai, M.; Shiromoto, Y.; Ota, H.; Song, C.; Kossenkov, A.V.; Wickramasinghe, J.; Showe, L.C.; Skordalakes, E.; Tang, H.Y.; Speicher, D.W.; et al. ADAR1 controls apoptosis of stressed cells by inhibiting Staufen1-mediated mRNA decay. Nat. Struct. Mol. Biol. 2017, 24, 534-543. [CrossRef] [PubMed] 
174. Shelton, P.M.; Duran, A.; Nakanishi, Y.; Reina-Campos, M.; Kasashima, H.; Llado, V.; Ma, L.; Campos, A.; Garcia-Olmo, D.; Garcia-Arranz, M.; et al. The secretion of miR-200s by a PKCzeta/ADAR2 signaling axis promotes liver metastasis in colorectal cancer. Cell Rep. 2018, 23, 1178-1191. [CrossRef] [PubMed]

175. George, C.X.; Ramaswami, G.; Li, J.B.; Samuel, C.E. Editing of cellular Self-RNAs by adenosine deaminase ADAR1 suppresses innate immune stress responses. J. Biol. Chem. 2016, 291, 6158-6168. [CrossRef] [PubMed]

176. Liddicoat, B.J.; Hartner, J.C.; Piskol, R.; Ramaswami, G.; Chalk, A.M.; Kingsley, P.D.; Sankaran, V.G.; Wall, M.; Purton, L.E.; Seeburg, P.H.; et al. Adenosine-to-inosine RNA editing by ADAR1 is essential for normal murine erythropoiesis. Exp. Hematol. 2016, 44, 947-963. [CrossRef] [PubMed]

177. Aspesi, A.; Ellis, S.R. Rare ribosomopathies: Insights into mechanisms of cancer. Nat. Rev. Cancer 2019, 19, 228-238. [CrossRef]

178. Yu, Q.H.; Wang, S.Y.; Wu, Z. Advances in genetic studies of inherited bone marrow failure syndromes and their associated malignancies. Transl. Pediatr. 2014, 3, 305-309. [CrossRef]

179. Bagby, G.C.; Meyers, G. Bone marrow failure as a risk factor for clonal evolution: Prospects for leukemia prevention. Hematol. Am. Soc. Hematol. Educ. Progr. 2007, 40-46. [CrossRef]

180. Cazzola, M.; Della Porta, M.G.; Malcovati, L. The genetic basis of myelodysplasia and its clinical relevance. Blood 2013, 122, 4021-4034. [CrossRef]

181. Malcovati, L.; Ambaglio, I.; Elena, C. The genomic landscape of myeloid neoplasms with myelodysplasia and its clinical implications. Curr. Opin. Oncol. 2015, 27, 551-559. [CrossRef] [PubMed]

182. Follo, M.Y.; Finelli, C.; Mongiorgi, S.; Clissa, C.; Bosi, C.; Martinelli, G.; Blalock, W.L.; Cocco, L.; Martelli, A.M. PKR is activated in MDS patients and its subcellular localization depends on disease severity. Leukemia 2008, 22, 2267-2269. [CrossRef] [PubMed]

183. Papaemmanuil, E.; Cazzola, M.; Boultwood, J.; Malcovati, L.; Vyas, P.; Bowen, D.; Pellagatti, A.; Wainscoat, J.S.; Hellstrom-Lindberg, E.; Gambacorti-Passerini, C.; et al. Somatic SF3B1 mutation in myelodysplasia with ring sideroblasts. N. Engl. J. Med. 2011, 365, 1384-1395. [CrossRef] [PubMed]

184. Wang, C.; Sashida, G.; Saraya, A.; Ishiga, R.; Koide, S.; Oshima, M.; Isono, K.; Koseki, H.; Iwama, A. Depletion of Sf3b1 impairs proliferative capacity of hematopoietic stem cells but is not sufficient to induce myelodysplasia. Blood 2014, 123, 3336-3343. [CrossRef]

185. Pellagatti, A.; Boultwood, J. Recent Advances in the 5q-Syndrome. Mediterr. J. Hematol. Infect. Dis. 2015, 7, e2015037. [CrossRef]

186. Goudarzi, K.M.; Lindstrom, M.S. Role of ribosomal protein mutations in tumor development (Review). Int. J. Oncol. 2016, 48, 1313-1324. [CrossRef]

187. De Keersmaecker, K.; Atak, Z.K.; Li, N.; Vicente, C.; Patchett, S.; Girardi, T.; Gianfelici, V.; Geerdens, E.; Clappier, E.; Porcu, M.; et al. Exome sequencing identifies mutation in CNOT3 and ribosomal genes RPL5 and RPL10 in T-cell acute lymphoblastic leukemia. Nat. Genet. 2013, 45, 186-190. [CrossRef]

188. Palomero, T.; Sulis, M.L.; Cortina, M.; Real, P.J.; Barnes, K.; Ciofani, M.; Caparros, E.; Buteau, J.; Brown, K.; Perkins, S.L.; et al. Mutational loss of PTEN induces resistance to NOTCH1 inhibition in T-cell leukemia. Nat. Med. 2007, 13, 1203-1210. [CrossRef]

189. Martelli, A.M.; Paganelli, F.; Fazio, A.; Bazzichetto, C.; Conciatori, F.; McCubrey, J.A. The key roles of PTEN in T-Cell acute lymphoblastic leukemia development, progression, and therapeutic response. Cancers 2019, 11, 629. [CrossRef]

190. Villegas, S.N.; Gombos, R.; Garcia-Lopez, L.; Gutierrez-Perez, I.; Garcia-Castillo, J.; Vallejo, D.M.; Da Ros, V.G.; Ballesta-Illan, E.; Mihaly, J.; Dominguez, M. PI3K/Akt cooperates with oncogenic notch by inducing nitric oxide-dependent inflammation. Cell Rep. 2018, 22, 2541-2549. [CrossRef]

191. Grzes, K.M.; Swamy, M.; Hukelmann, J.L.; Emslie, E.; Sinclair, L.V.; Cantrell, D.A. Control of amino acid transport coordinates metabolic reprogramming in T-cell malignancy. Leukemia 2017, 31, 2771-2779. [CrossRef] [PubMed]

192. Sulima, S.O.; Patchett, S.; Advani, V.M.; De Keersmaecker, K.; Johnson, A.W.; Dinman, J.D. Bypass of the pre-60S ribosomal quality control as a pathway to oncogenesis. Proc. Natl. Acad. Sci. USA 2014, 111, 5640-5645. [CrossRef] [PubMed]

193. Lipton, J.M.; Ellis, S.R. Diamond Blackfan anemia 2008-2009: Broadening the scope of ribosome biogenesis disorders. Curr. Opin. Pediatr. 2010, 22, 12-19. [CrossRef] 
194. Wang, R.; Yoshida, K.; Toki, T.; Sawada, T.; Uechi, T.; Okuno, Y.; Sato-Otsubo, A.; Kudo, K.; Kamimaki, I.; Kanezaki, R.; et al. Loss of function mutations in RPL27 and RPS27 identified by whole-exome sequencing in Diamond-Blackfan anaemia. Br. J. Haematol. 2015, 168, 854-864. [CrossRef] [PubMed]

195. Kirwan, M.; Dokal, I. Dyskeratosis congenita: A genetic disorder of many faces. Clin. Genet. 2008, 73, 103-112. [CrossRef] [PubMed]

196. Zhang, Y.; Morimoto, K.; Danilova, N.; Zhang, B.; Lin, S. Zebrafish models for dyskeratosis congenita reveal critical roles of 553 activation contributing to hematopoietic defects through RNA processing. PLoS ONE 2012, 7, e30188. [CrossRef] [PubMed]

197. Pereboom, T.C.; van Weele, L.J.; Bondt, A.; MacInnes, A.W. A zebrafish model of dyskeratosis congenita reveals hematopoietic stem cell formation failure resulting from ribosomal protein-mediated p53 stabilization. Blood 2011, 118, 5458-5465. [CrossRef] [PubMed]

(C) 2019 by the authors. Licensee MDPI, Basel, Switzerland. This article is an open access article distributed under the terms and conditions of the Creative Commons Attribution (CC BY) license (http://creativecommons.org/licenses/by/4.0/). 